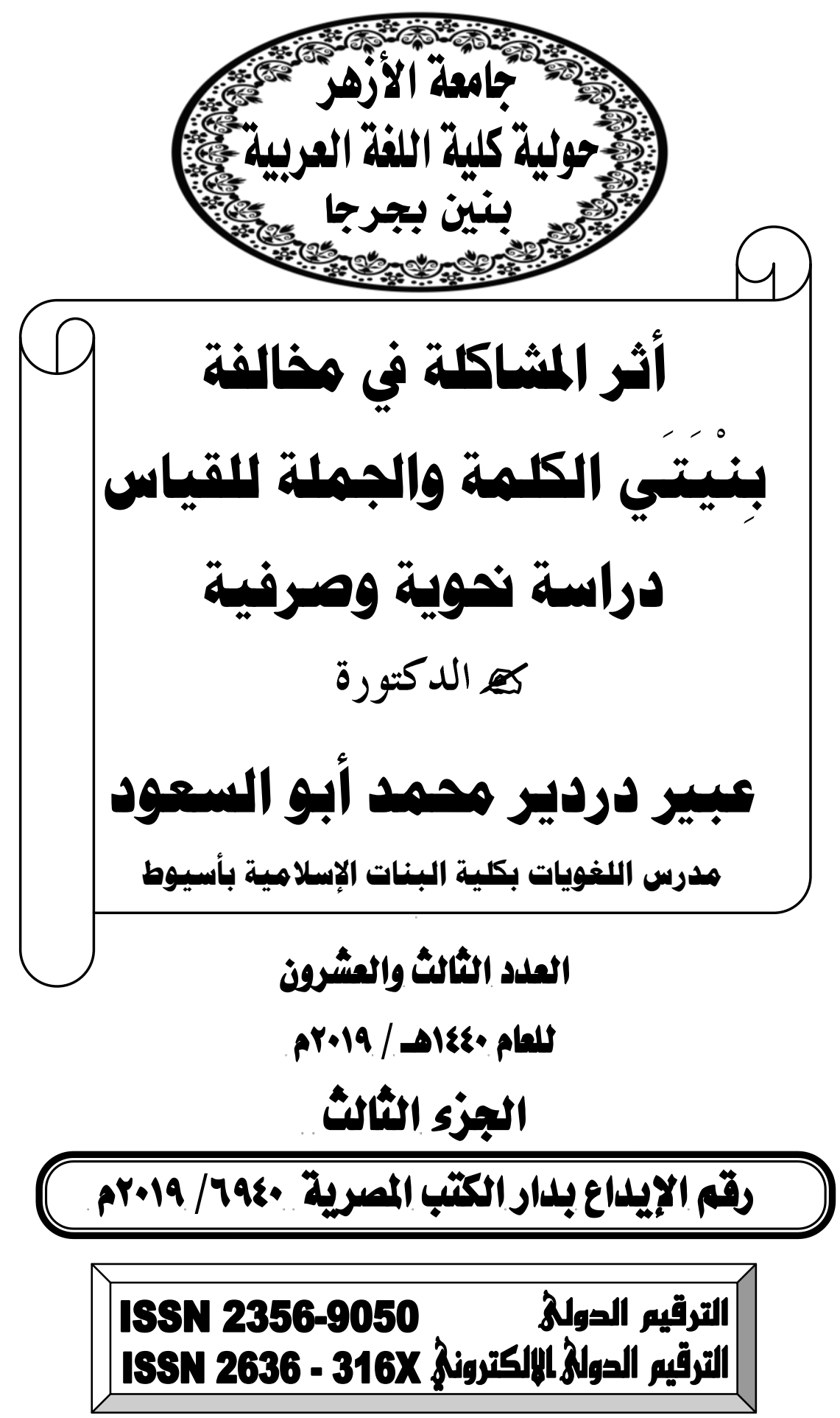




\section{هلخص البحث}

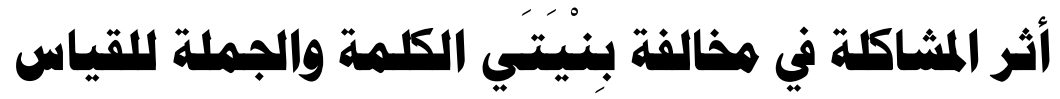

\section{دراسة نهوية وصرفية بون}

إن اللغة العربية تعد من أعرق لغات البشر ، كما أنّ دراستها من

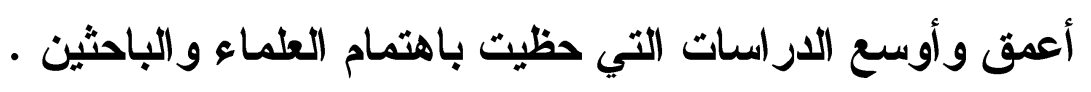

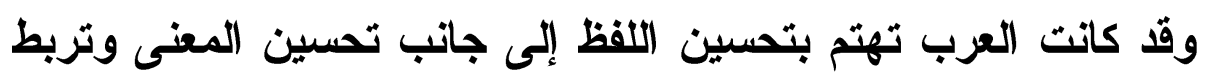

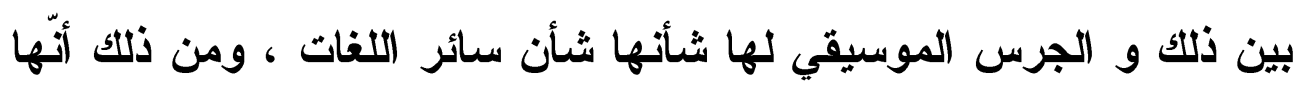
كانت تراعي مجاورة الألفاظ لبعض فتحمل اللفظ على مجاوره لمجرد

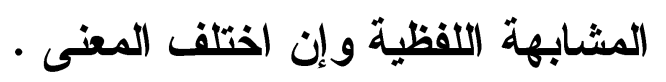
وانطلاقا من هذا الكلام فقد كان للعرب محسنات لفظية من بينها المشاكلة . وهى أسلوب من أساليب العرب ، وطرفة من طرفهم ، ومُّحة من ملح

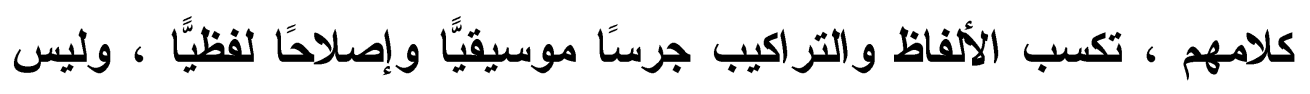

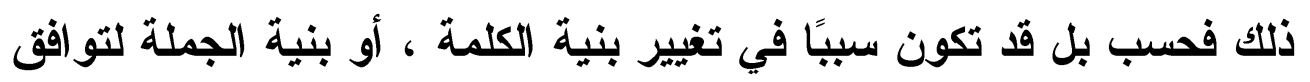

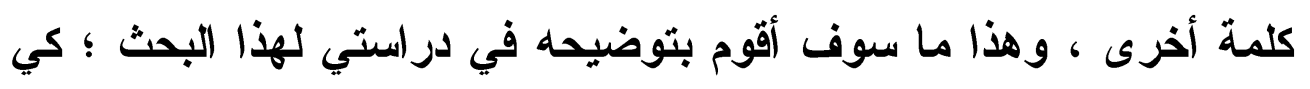
أكثف النقاب في بعض النماذج عن ما تم فيه مخالفة القياس من أجل هذا لـأ

\section{كمهِ الدكتورة}

\section{عبير دردير همهمد أبو السمود}

مدرس اللغويات بكلية البنات الإسلامية بأسيوط

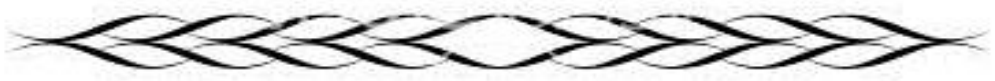




\section{الترقير الدولخ \\ ISSN 2356-9050}

\section{Research Summary}

\section{The effect of the problem in violating the structure}

of the word and the sentence for measurement

\section{Grammatical and morphological study}

The Arabic language is one of the oldest languages of human beings, and the study of the deepest and most extensive studies that received the attention of scientists and researchers.

The Arabs were interested in improving the word besides improving the meaning and linking it to the musical bell like all the other languages, and that it was taking into account the proximity of words to some of the word around the mere verbal similarity and if the meaning varied.

Based on this talk, the Arabs had verbal improvements, including the problems.

It is one of the methods of the Arabs, and on the other side of them, and urgent from the salt of their words, the words and structures gain a musical and verbal reform, and not only that, but may be a reason to change the structure of the word, or the syntax of the sentence to match another word, and this is what I will explain in my study of this In order to reveal in some models what measurement has been violated for this enhancer.

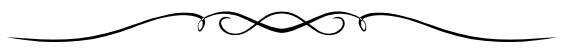

Dr.

\section{Abeer Dardir Mohammed Abu Al - Saud}

Instructor of linguistics at the Faculty of Islamic Girls in Assiut 


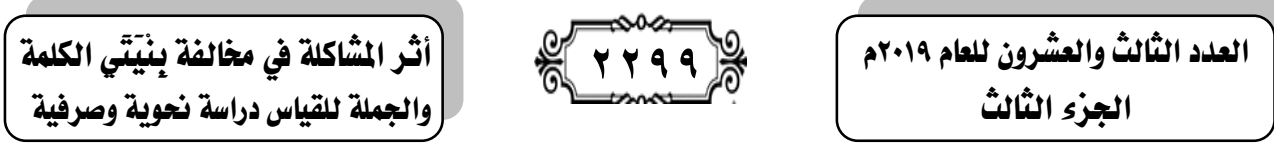

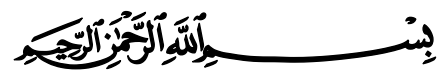

\section{المقدهة}

الحمد الله نحمده ونستعينه ونستغفره ونستهـيه ، ونعوذ بــهـ مـن

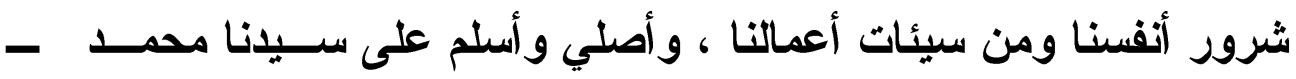
صلى الله عليه وسلم - وعلى آله وصحبه وسلم

أهما بهد:

فإن اللغة العربية تعد من أعرق لغات البشر ، كما أنّ دراستها من أعمق وأوسع الار اسات التي حظيت باهنمام العلماء والباحثين .

وقا كاتت العرب تهتم بتحسين اللفظ إلى جاتسـب تحسـين المعنـى وتربط بين ذلك و الجرس الموسيقي لها شأنها شأن سائر اللغات ، ومن ذلك أنّها كاتت تراعي مجاورة الأكفاظ لبعض فتحمل اللفظ على مجاوره لمجــرد المشابهة اللفظية و إن اختلف المعنى •

وانطلاقا من هذا الكلام فقد كان للعرب محسنات لفظية مــن بينهـــا

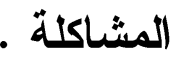

وهى أسلوب من أساليب العرب ، وطرفة من طرفهم ، ومُلحة من ملح كلامهم ، تكسب الألفاظ و التر اكيب جرسيًا موسيقيًّا و إصلاحًا لفظيَّا . وقا آثزث الكلام عن هذه الظاهرة لما يأتي : ا- الوقوف على مدى وجود هذه الظاهرة في الكلام الفصيح المعثدّ

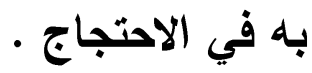

r- مدى ما تحدثة من تغييز في البنية مخالفا للقياس وهل كل ما

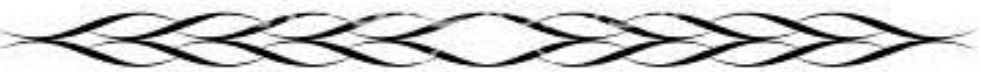




\section{الترقيم الدوله \\ ISSN 2356-9050}

وقعت فيه مخالف أو له وجه يمكن أن يرد إليه .

r- بيان كيف أن العرب اهتمت باللفظ كما اهتمت بالمعنى والقاعدة

التي بنت كلامها عليها.

وقد اخترت لهذه الاراسة بعض النماذج عن ما تم فيه مخالقة القياس

من أجل هذه الظاهرة ، مثل : " مأزورات " في قوله ــ صلى الله عليه وسلم

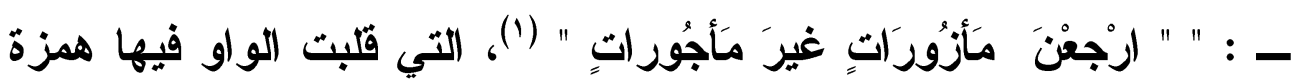
على غير قياس لمشاكلة " مأجور ات " .

وما عدل فيه عن قياس غالب إلى قياس غير غالب ، كما عدل عن

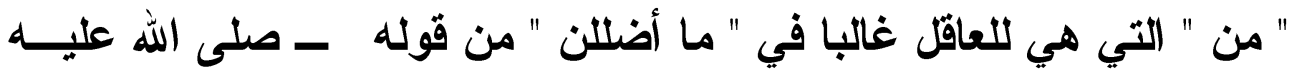

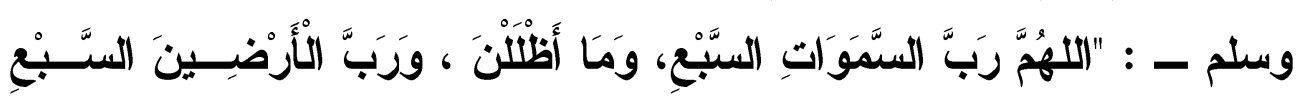

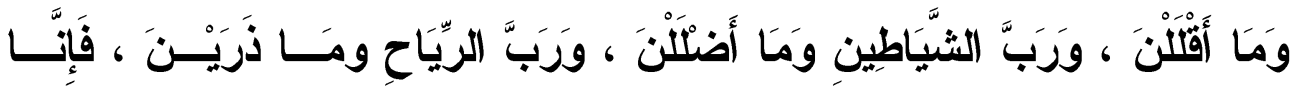

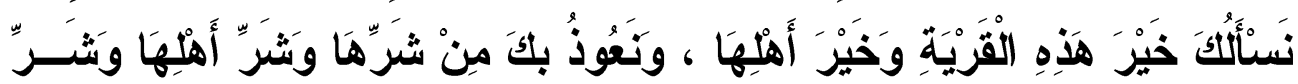
مَا فِيهَا "(r) إلى " ما " التي ثنأتي لغير العاقل في الغالب لمشاكلة " ما " التـي معها في باية الحديث (r).

(1) انظر : سنن ابن ماجه // . .0 باب ما جاء في إتباع النساء الجنائز ، انظر البحث $.119 \leq 0$

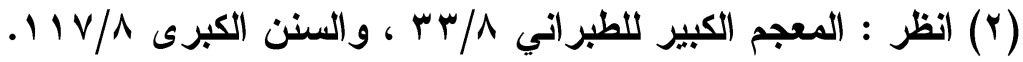

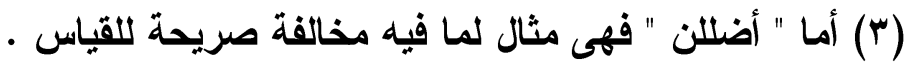




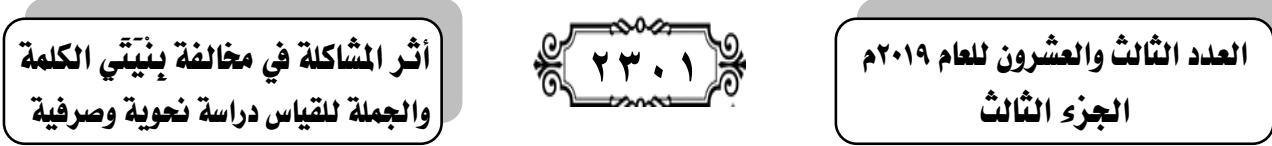

وما عدل فيه عن صياغة للكلمة من أصل اثتتهر سماعه إلى أصل أقل شهرة ، كما عدل عن " يبدأ " وأصله " بدأ " في قوله ــ تعالى ــ : " إنَّهُ

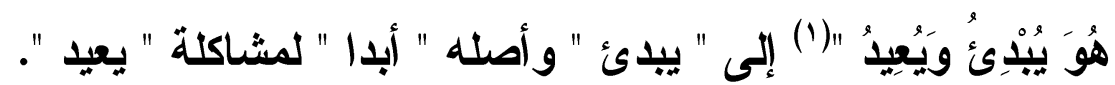
وهذه الظاهرة قد اختلفت تعبيزات النحويين عنها فتارة يسـمونها مشاكلة ، وأخرى يسمونها إتباعًا أو مزاوجة أو محاذاة ، وهذا يعد عنــدم من باب اختلاف الأسماء لمسمى واحد . أمـا اللغويون والبلاغيون فلايهم لكل ظاهرة مــن هــذه الظـــواهر تعريف خاص بها ، وهذا ما سوف أوضحه في التمهيد . وقد اقتضث طبيعة الاراسة في هذا البحث أن تثكون من مقدمسـة ، وتمهيل ، ومسائل ناقشت فيها نماذج لهذه الظاهرة ، وخاتمــة ، وفهــارس فنية

فالاقدهة : تكلمت فيها عن أهمية الموضوع ، وطريقة السير فيه . والتمهيد : تكلمت فيه عن مدلول ألفــاط المشـــاكلة ، والإتبــاع ، والمزاوجة ، والمحاذاة عند اللغويين ، والبلاغيين ، والنحــويين ، وســبب لجوء العرب إلى استعمال هذه الألفاظ .

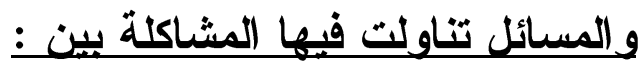

ا-ـ " تلخلوا ، تؤمنوا " و " تؤمنوا ، تحابوا " ، في قوله ـ صلى الله عليه

وسلم - : " لا تلاخلوا الجنة حتى تؤمنوا ، ولا تؤمنوا حتى تحابوا ".

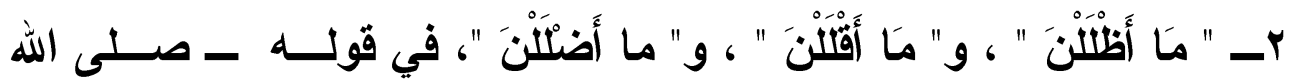

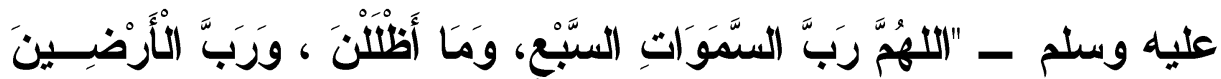

$$
\text { (1) الآية (r ا ) في سورة " البروج " . }
$$




\section{الترقير الدولخ}

ISSN 2356-9050 $\frac{0}{r r \cdot r}$
حولية كلية اللفة العربية بجرجا مجلة علمية محكمة

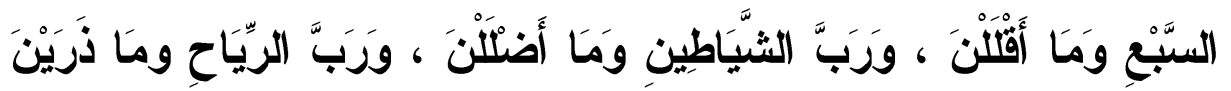

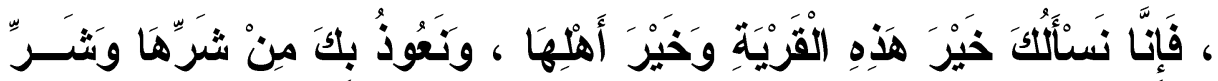

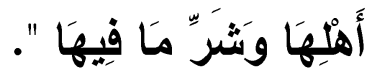

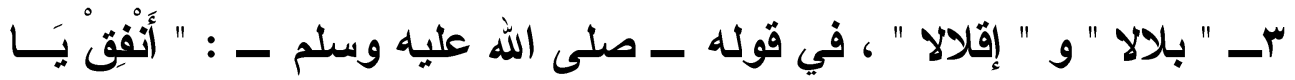

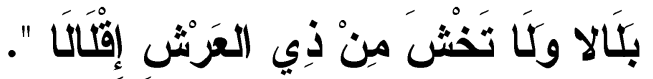

عــ " قَدُم " و " حَدُث " ، الواردة في حديث النهي عن الكعلام في الصلاة ــ : " فأخذني ما قَدَم وما حَدُث ".

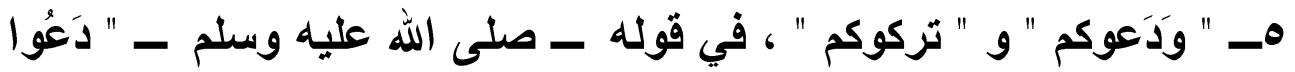

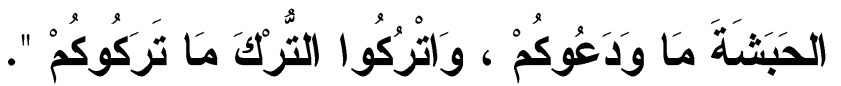

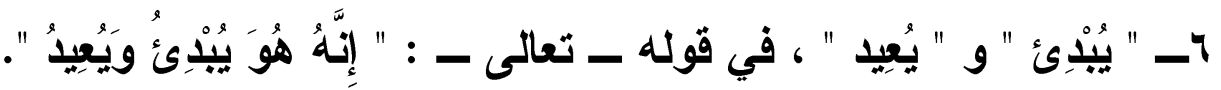

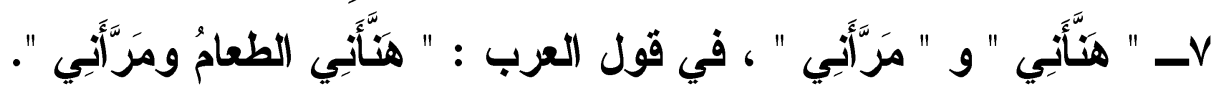

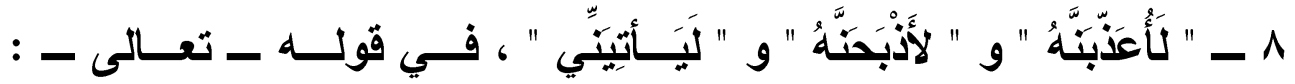

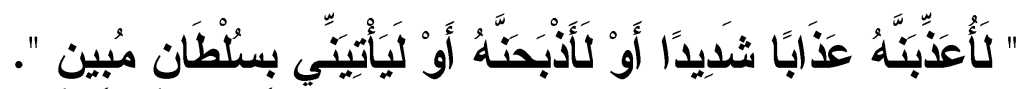

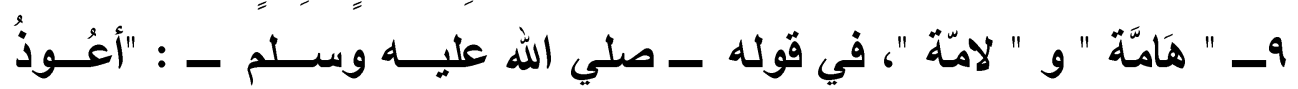

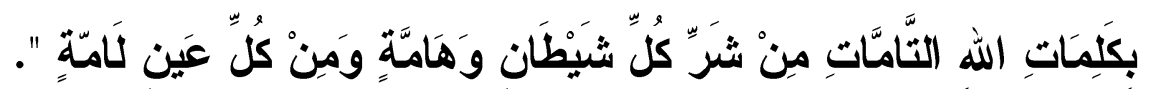

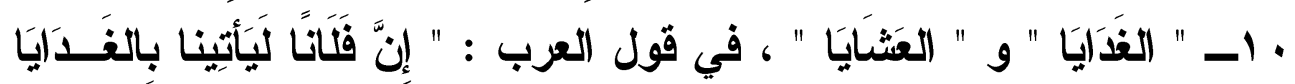

$$
\begin{aligned}
& \text { وَالعَثَايَا ". } \\
& \text { 11 }
\end{aligned}
$$

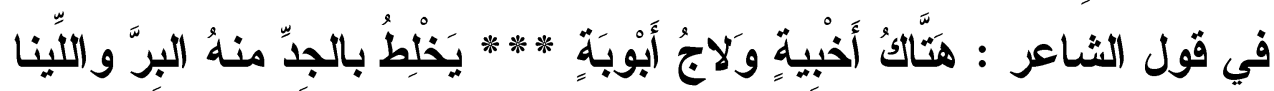

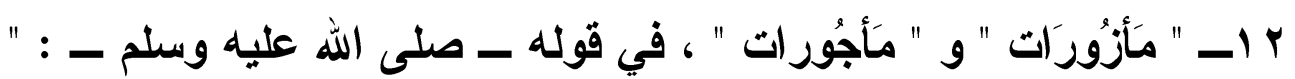

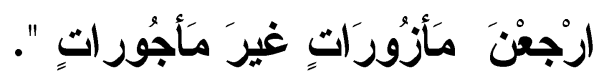




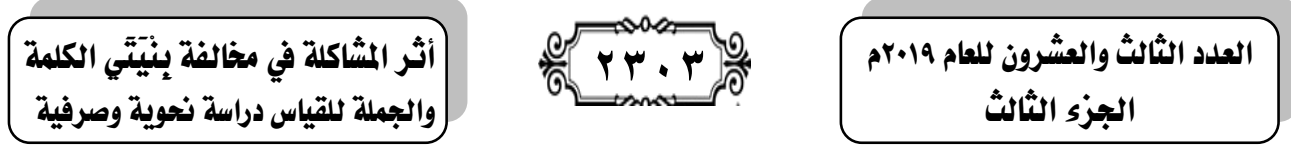

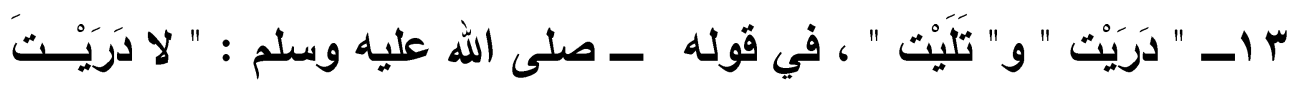
ولا تَلَيْتَ "

ع ا- " أَوْبَةً " وَ" طَوْبَةً " ، في قَول العرب للرجل إذا قدم من سفر . وقد ألحقت كل واحد من هذه النماذج بابـــهـ النحــوي أو الصــرفي ،

ووضعت له عنو انًا مناسبًا متبعة في ثرتيبه ترتيب ابن مالك في الألفية.

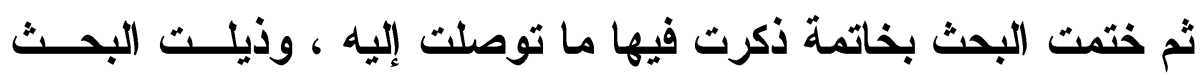
بثبث بأهم المصادر والمراجع •

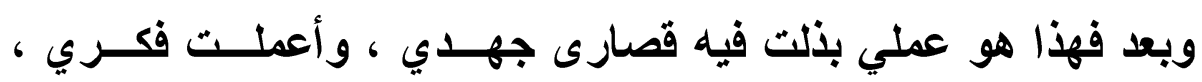
وحاولت أن أخرج به في صورة مُنْلى ، فَإن أكن قد وفقت فبفضل مسن الله ونعمة ، وإن تكن الأخرى فحسبي أنتي اجتهدت لإخراج هذا البحث في هذه الصورة .

واسأل الله ــ تعالى ـ أن يجعل ثواب هذا العمل في ميـز ان حســـات

والاَيَّ وحسناتي ، وأن يغقر لي ولهما .

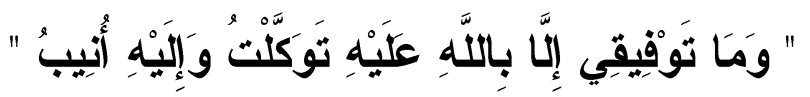

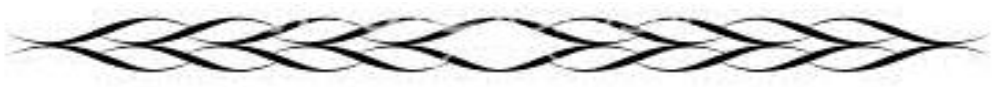




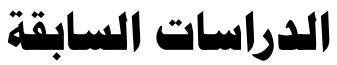 \\ أولا : كتب التزاث}

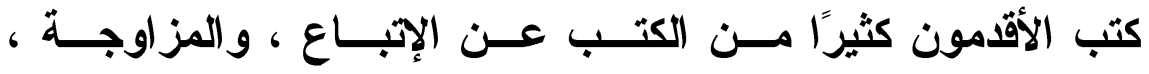

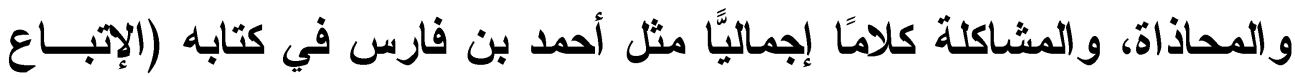
والمزاوجة)، وأبي علي القالي في كتابه (الإباع)، وابن أبي العز في كتابــهـ

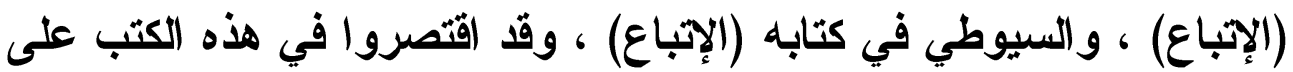

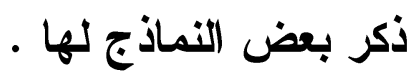

وقد قت في هذا البحث بدراسة المشاكلة وذكرت نماذج لها دراسة

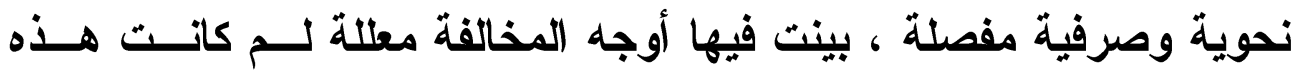
الصورة التي جاءت عليه مخالفة للقياس، وما هذا القياس الذي تُرك ولماذا.

\section{ثانيا : الدراسات الحديثة}

هناكك بعض الأبحاث درس فيها ظاهرة المشاكلة وتناول كـلـل منهــــا جانبا أو تخصصا معينا، منها : 1ـ أسلوب المشاكلة دراسة بلاغية ـ جاسم سليمان حمـــ ـ الناثــر دار

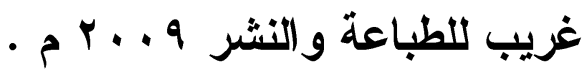
r- جمالية المشاكلة في مختار ات المتتبي ـ شارف عبد الكــريم ــ مجلـــة

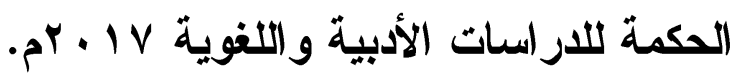

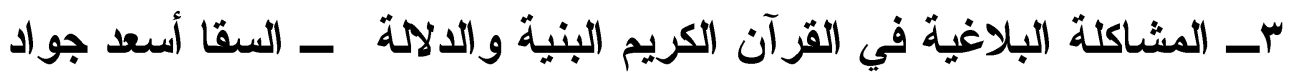

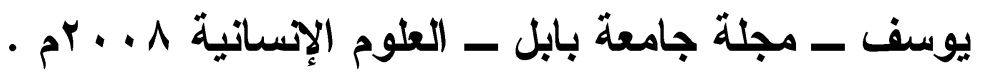




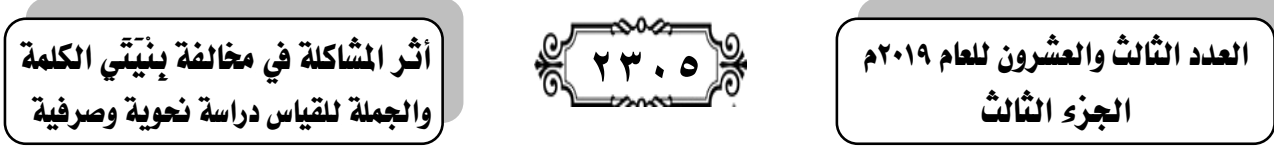

عــ المشاكلة الصوتية وينية النص لإمبية عبد الوهاب خلف الله ــ مجلـة

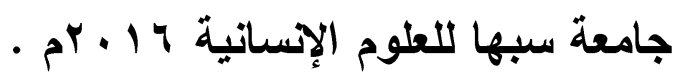

هـ المشاكلة في سورة البقرة ـ أحمد لقمان فتاح ـ مجلة الفنــون والأدب وعلوم الإسمانيات والاجتماع ، الناشر : كلية الإمارات للعلوم التربويــة $\cdot p^{\prime} \cdot 17$

צ- المشاكلة في شعر حسين عرب القثامي - أمل بنت محيسن بن عواض - رسالة ماجستير - جامعة أم القرى 7 ، . ب م .

V- المشاكلة في اللغة العربية صوتيَّا وصرفيًّا ــ هاثم مــاهر خضــير -

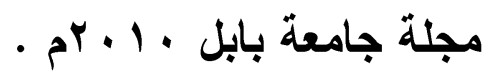

وعنوان هذا البحث قريب من عنوان بحثي في الظاهر ، ولكن كان

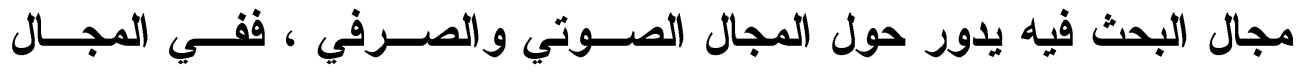
الصوتي درس مظاهز التشاكل الصوتي ، والإتباع الحركـي ، والإدغــام ،

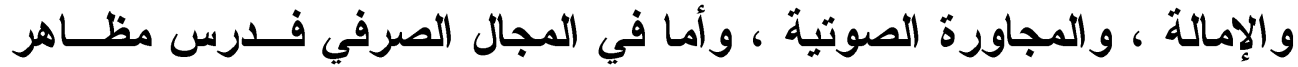
التشاكل في القاصلة القر آنية ، والمزاوجة ، والمشابهة . وهذه الدراسة بعيدة كل البعد عن در استي فقد قمت بدر اسة الظاهرة من حيث معناها ، وأنواعها كما قمت بلر اسة بعض نماذج لهــــه الظــاهرة در اسة نحوية وصرفية ، موضحة وجه مخالفتها للقياس ، وإن كان لها وجه آخر في اللغة يتوافق مع القياس ذكرته . 


\section{الترقيم الدولم \\ ISSN 2356-9050}

\section{التمهمهيد}

\section{المشاكلة والمزاوجة والإتباع والحاذاة}

كاتت العرب تُغير كثيرًا من كلامها وتخرج عن قو اعــدها النحويــة والصرفية ، وبالبحث وجدث أنّ ذلك كان لأجل المشاكلة والإتباع والمزاوجة

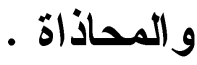

فهذه ألفاظ مشتركة بين كلٍ من اللغويين والبلاغيين والنحــينين ، و لكن لكل منهم تعريفاته الخاصة . • مدلول هذه الألفاظ في الاغة :

ا-ـ المشاكلة هى الشبه والمثل ، تشـاكل الشيئنان وشاكل كل واحـــ منهمـــا الآخر ، أي : شابهه وماتله (1).

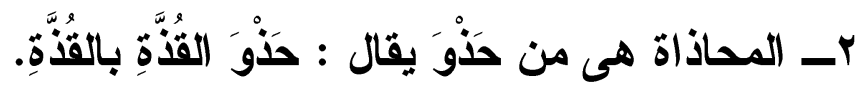

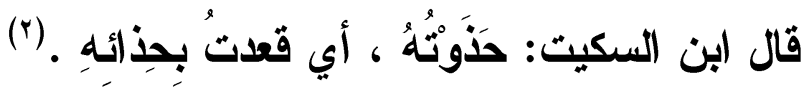
والمحاذاة هي ظاهرة صوتية ، صرفية ، نحوية ، دلاليــة ، ولعـل أول من استعمل هذا المصطلح في العربية هو أحمد بن فارس عندما عقـــ لها بابا في كتابه ( الصاحبي ) سماه " باب المحاذاة " ، وعرفهـــا بقولــه :

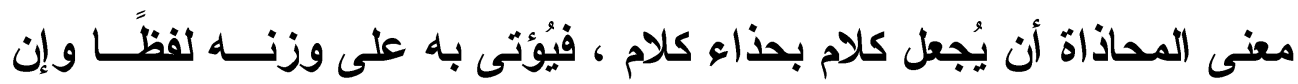

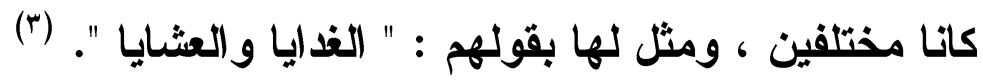

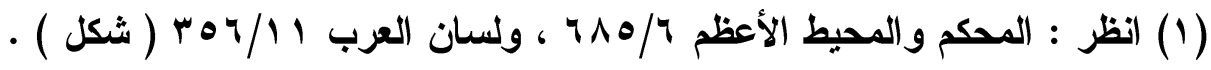

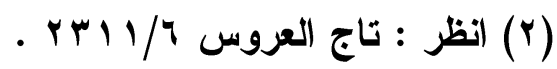
. IV ع ( الصاحبي (r) 


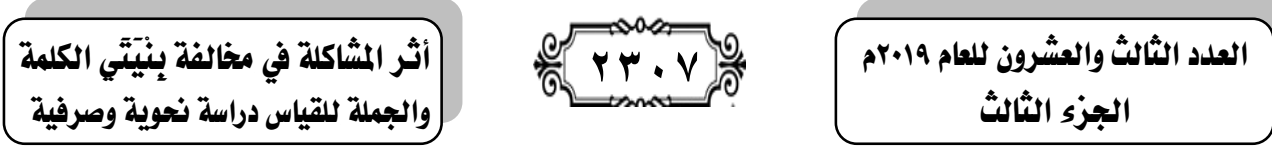

وعرفها الزركثي بقوله : " أن يُؤتْى باللفظ على وزن الآخر لأجـلـ انضمامه إليه وإن كان لا يجوز فيه ذلك لو استعمل منفردًا كقولهم : " أَتَبَتُهُ

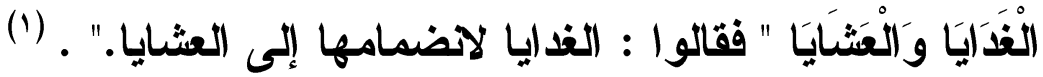

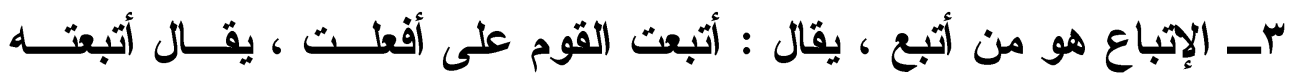
الشيء فتبعه ، وأتبعه الشيء: جعله لله تابعا (؟).

عـــ المزاوجة هى من زوج ، يقال زوج الثيء بالثيء ، وزوجــهـ إليـــه : قرنه

ازدوج الكلام وتزاوج : أشبه بعضه بعضا في الســجع أو الــوزن

أو كان لإحدى القضيتين تعلق بالأخرى . (")...

وقال الكفوي : " الازدواج هو فِي البديع تناسب المتجاورين، نحو : " مِنْ

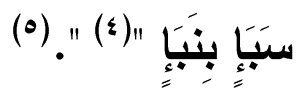

وقدعقد لها (بن قتيبة بابا في كتابه (أدب الكاتب) سماه " باب تأويل

المستعمل من مزدوج الكلام " .

والمز اوجة ليست شيئا مختلفا عما سبقها من مصطلحات .

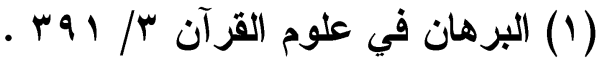

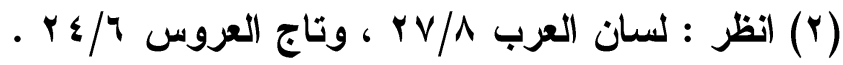

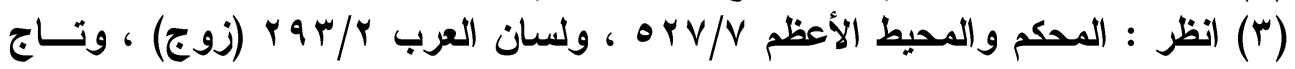

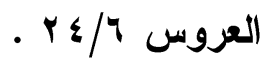

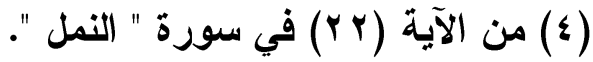

(0) الكليات الابه 


\section{الترقير الدولخ}

ISSN 2356-9050
Q.
حولية كلية اللفة العربية بجرجا

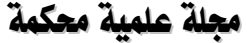

وأما ما صنعه (بن فارس من تسميته كتابه ( الإتباع و المز اوجة ) مع

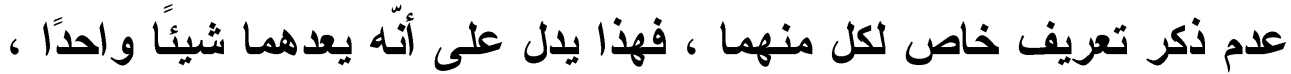
وأما عطفه أحدها على الآخر فلعله من باب عطف الخاص على على العام .

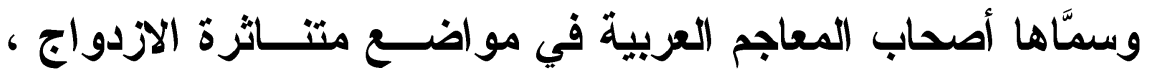

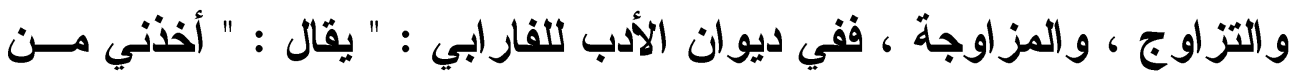

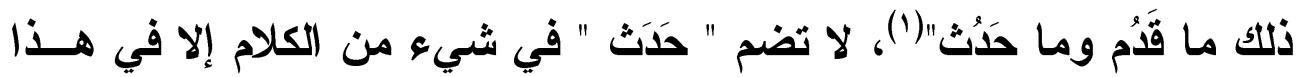

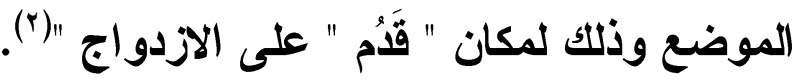

ومن هذه المعاني أخذ البلاغيون والنحويون تعريفاتهم الاصطلاحية :

• فحينما أتى البلاغيون على ذكر المشاكلة قالوا : إنها ذكر الثيء

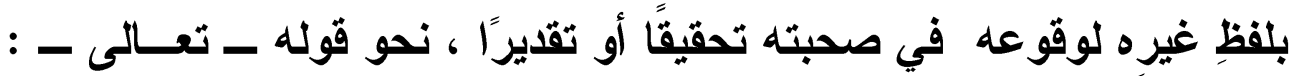

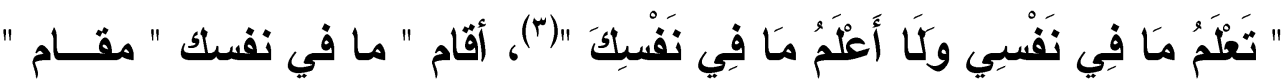

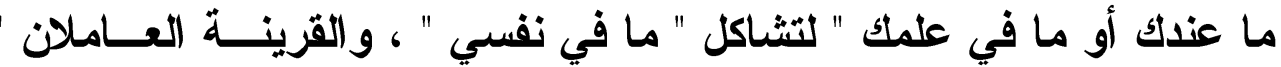

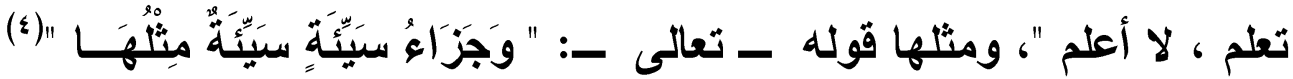

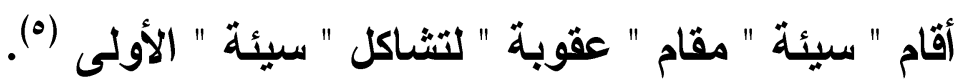

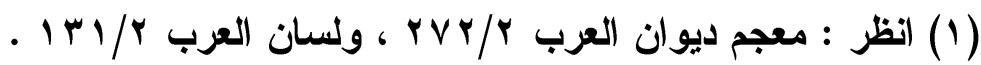

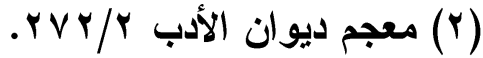

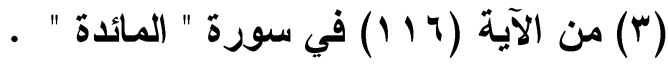

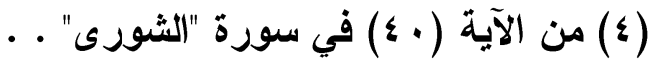

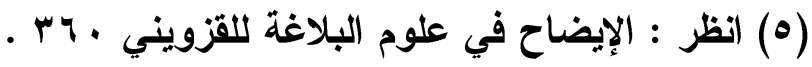


وذكروا أنّ المزاوجة هى أن يزاوج المتكلم بين معنيين في الثــرط

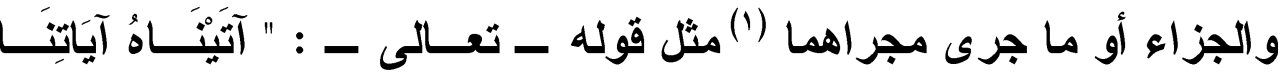

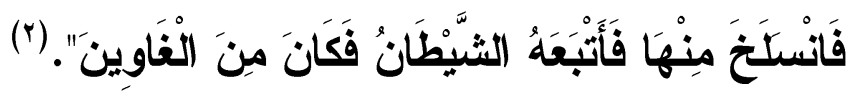

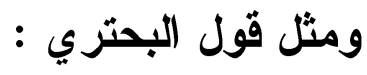

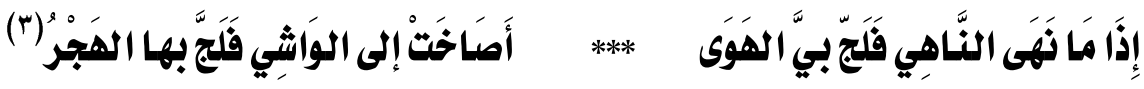

والإتباع هو أن تتبع الكلمة الكلمة على وزنها أو رويهــا إثــباعًا

وتأكيدًا (๕)

ولم يخالف النحويون اللغويين والبلاغيين في هذه المسميات ولكنها

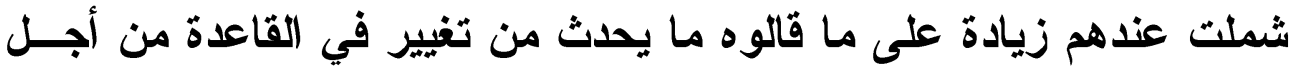

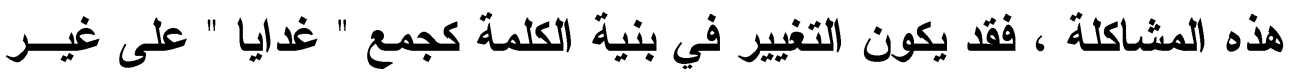

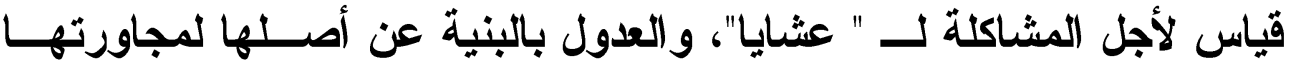
كلمة من بنية أخرى في قوله ــ صلى الله عليه وسلم ـ ـ أَعُوذُ بكَمِمَاتِ اللهِ

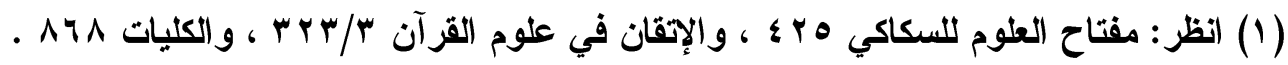

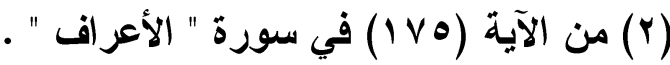

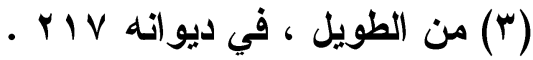

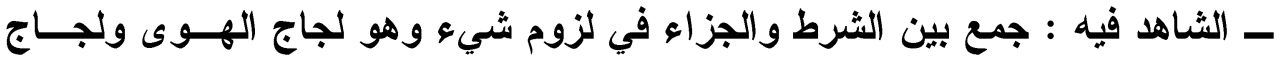

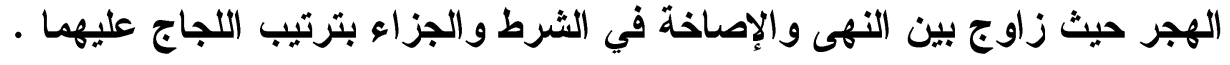

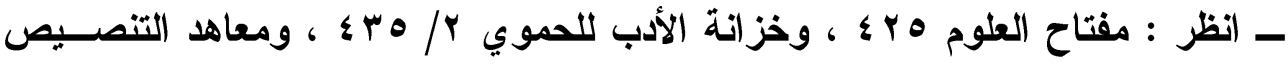
. roo/r

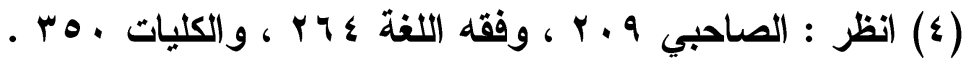




\section{الترقير الدولخ}

ISSN 2356-9050
Pril.
حولية كلية اللفة العربية بجرجا

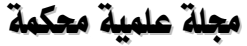

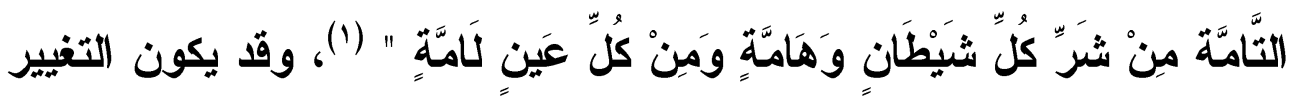

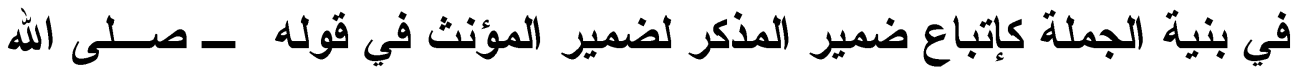

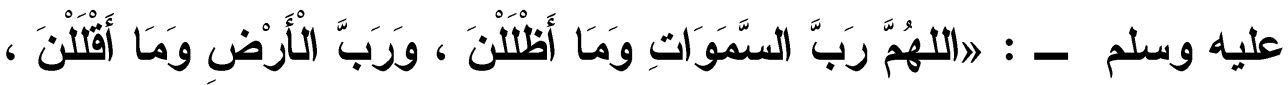

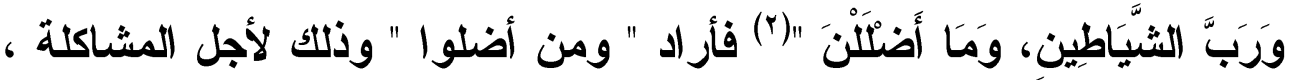

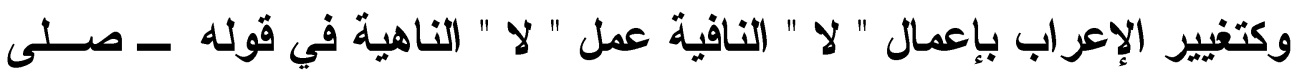

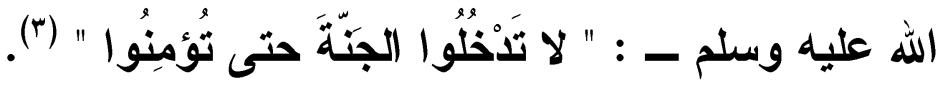

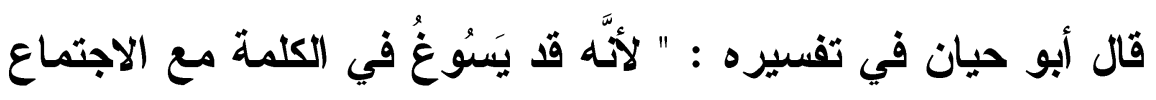

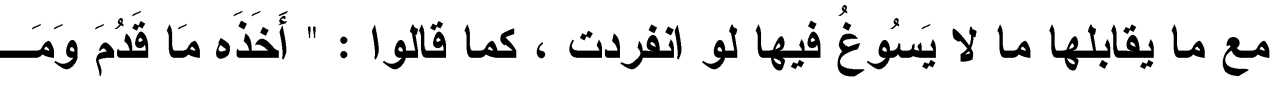

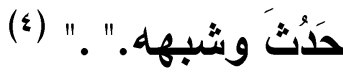

وقد خلصت من ذلك إلى أنّ المشاكلة عند النحويين هى تغيير فـي

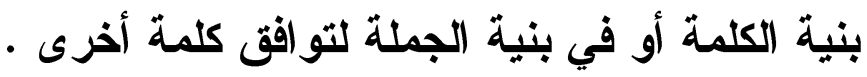

وياب المشاكلة واسع كبير كما قال ابن سيده : " وهذاواسع كثيـر

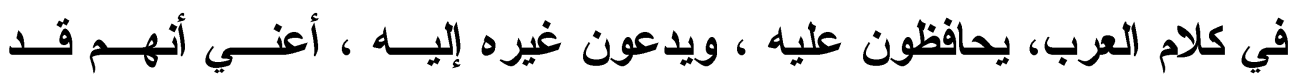

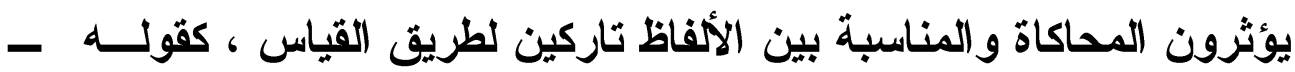

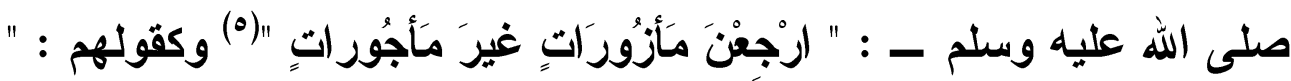
عيناء حوراء " ، من العين الحير. وإنما هو الحور، فآثروا قلب الواو يــاء

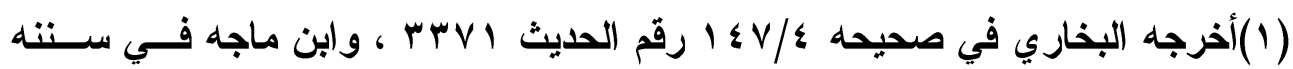

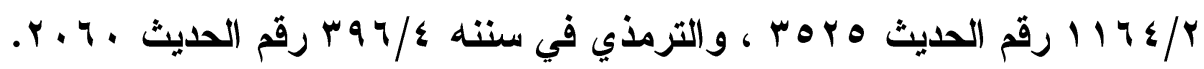

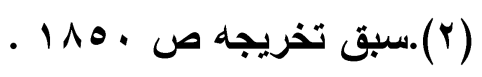

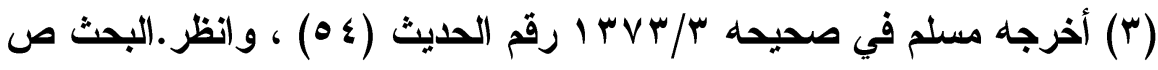

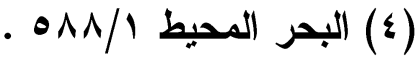

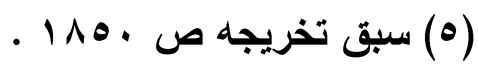




\section{الترقير الدولخ}

ISSN 2356-9050
Q
حولية كلية اللفة العربية بجرجا مجلة علمية محكمة

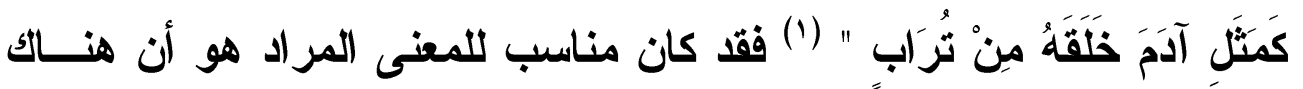
من ادّعى في المسيح الإهية فأتى سبحانه بلفظ التراب ليصغر أمر خلقه عند من ادّعى ذلك . من من

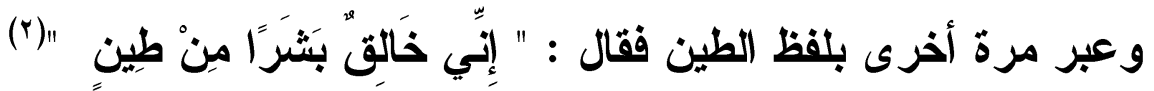

وذلك لثَّا أر اد سبحانه الامتنَان على بني إبر ائيل أخبرهم أن يخلق لهم مــن

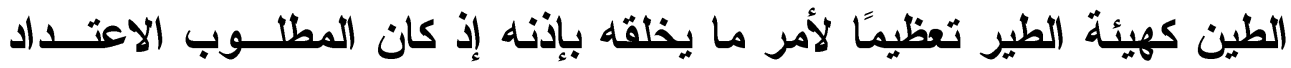

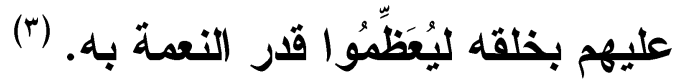

السبب في لجوع العرب إلمى استعمال هذه الأساليب :

لجأت العرب إلى هذه الأسباليب ؛ لأتّها كما كاتت تسعى دائمـــا إلــى التحسين ، والتحسين مرجعه إلى تحسين المعنى أصالة مع تحسـين اللفــا تبعا، أو مرجعه إلى تحسين اللافظ و إصلاحه .

قال ابن جني : " اعلم أنّهـ لما كاتت الألفاظ للمعاني أزمَّة ، وعليهـــا

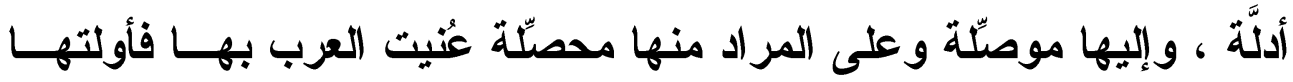

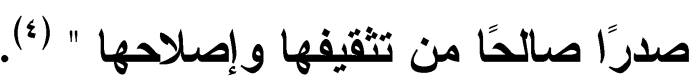
وذكروا لذلك صورًا متعددة ، قام فيها العرب بإصــلاح اللةـــ داخـلـل

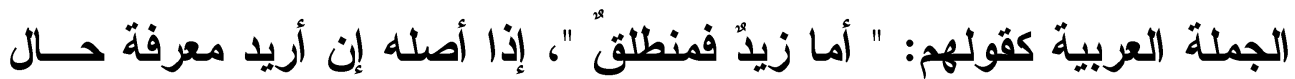
زيـ "فزيد منطلق"، حذفت أداة الشرط وفعل الثرط، وأنيبت "أمسا" مناب ذلك.

$$
\begin{aligned}
& \text { (1) من الآية (9ه) في سورة " آل عمران " . }
\end{aligned}
$$

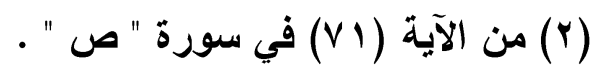

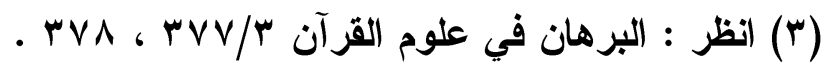

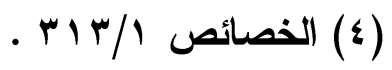




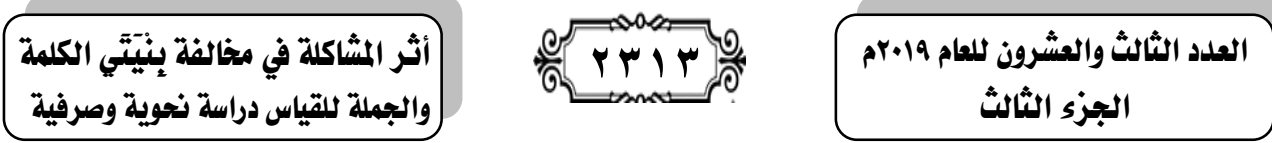

وقدر الجمهور " أما " في هذا بـ " مهما يكن من شـيء " ، فــإذا

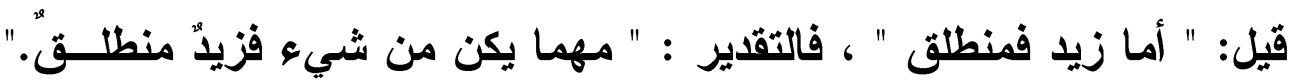
فحذف فعل الثرط وأداته ، وأقيمت " أمـا " مقامهما ، فصار التقدير : " أمــا فزيد منطلق." فأخرث الفاء إلى الجزء الثاني ؛ من أجل إصلاح اللفظ . (1) وكقولهم : " كأن زيدًا عمرو." وأصل الكلام : " زيدّ كعمـرو " ثــم أرادوا توكيد الخبر فز ادوا فيه "إنّ " فقالوا : " إنّ زيدًا كعمرو " ثم بالغوا في توكيا التشبيه فقدموا حرفه إلى أول الكلام عناية به و إعلامًا أن عقد الكــلام

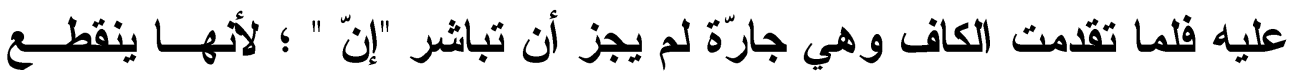
عنها ما قبلها من العوامل فوجب لألك فتحها فقالوا : " كأن زيدًا عمرٌو". (r) وقد أولى العلماء ظاهرة اهتمام العرب بتحسين الألفاظ عناية كبيزة، وأفردوا لها مباحث في مؤلفاتهم ، كما مرَّ من صنيع ابن جني فــي كتابــه الخصائص

كما أكدوا على قضية اهتمام العرب بالمشاكلة بين المعنى واللةـــ الأي يدل عليه، والمخاطب الأي يوجَّه له الكلام ، ويتضح ذلك فيما صنعه " ابن القيم " في كتابه " الطرق الحكمية " إذ يقول - بعد أن ذكر خبر بعـض

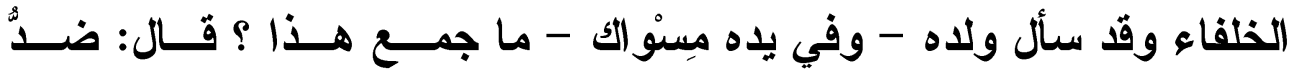
محاسنك يا أمير المؤمنين - : " وهذا من الفراسة في تحسين اللفظ. وهــو

(1) انظر : الخصائص / / آ ، وشرح المفصل لابـن يعـيش

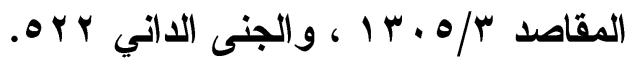
(Y) انظر : الخصائص 11/1 ا . 


\section{الترقير الدولخ}

ISSN 2356-9050
Tris
حولية كلية اللفة العربية بجرجا مجلة علمية محكمة

باب عظيم النفع ، اعتنى به الأكابر والعلماء. وله شواهد كثيرة في الســنة وهو من خاصية العقل و الفطنة .

ثم ذكر ما كان من عمر رضي الله عنه : حين خرج يَعُسُّ المدينـــة

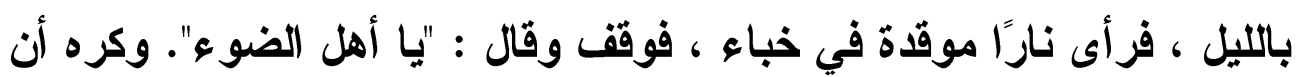

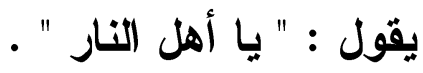

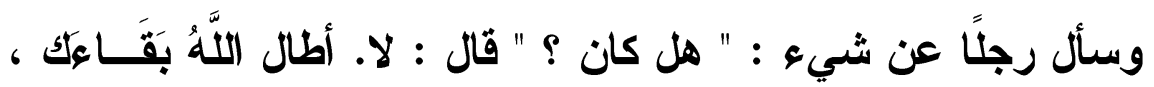

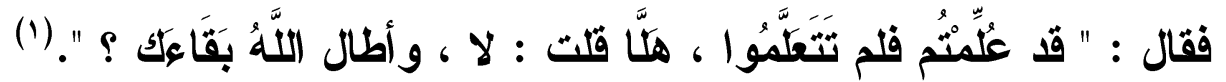
و انطلاقا من هذا القول قسم البلاغيون المحسنات إلي محسنات معنوية،

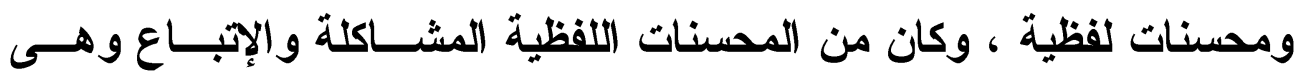

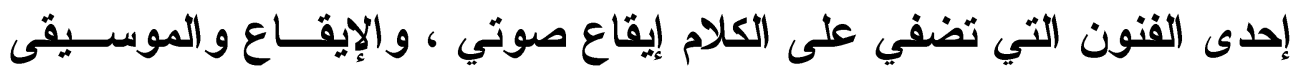

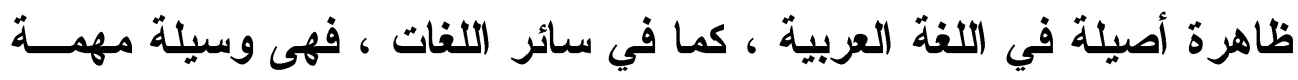

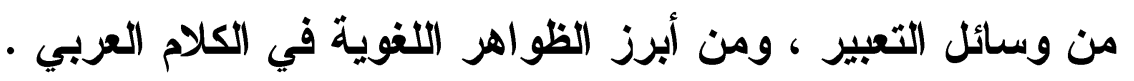
وما ياخل في اهتمام النحويين هو أثر هذه الظاهرة في بنية الكلمة أو الجملة . - - 20 - 20

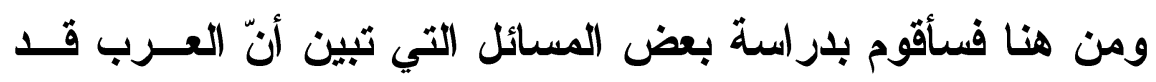

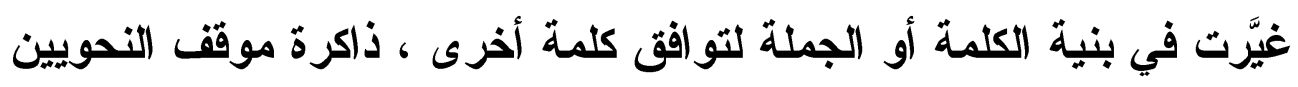

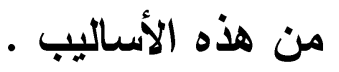




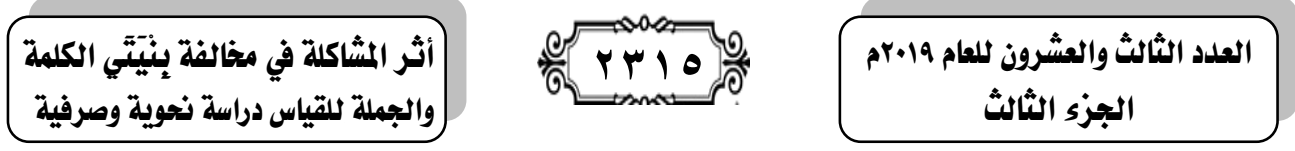

\section{حذف نون الرفع هن الفعل الاضضارع للمشاكلة}

وذلك في قوله ـ صلى الله عليه وسلم ـ : " لا تلخلوا الجنة حتى

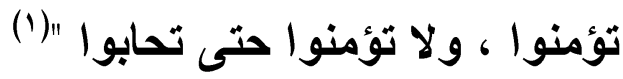

حيث جاء الفعلان " تلخظوا " ، و " تؤمنوا " الثانيــة فـــي الحـــيث

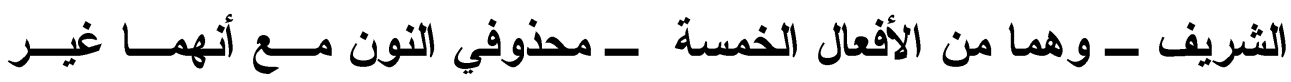

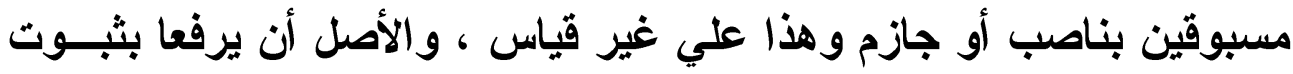

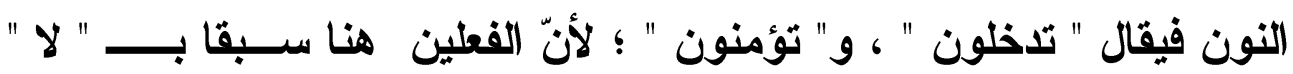

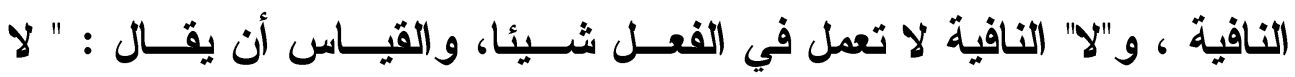

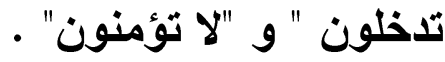
وييان ذلك فيما بأتي :

الأصل في الأفعال الخمسة أن ترفع بثبوت النون وذلك إن لم تسبق

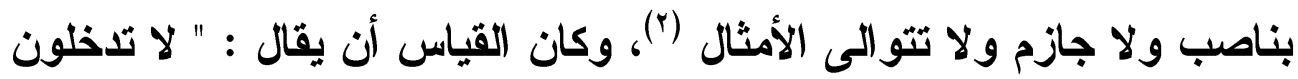

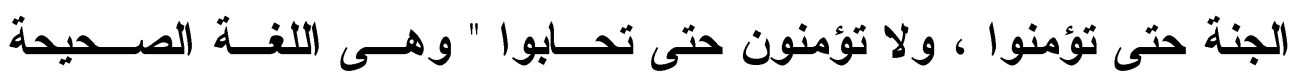

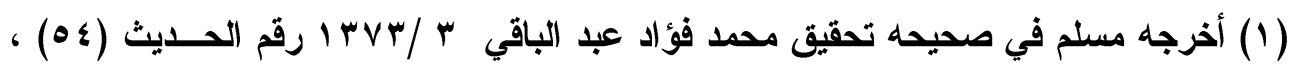

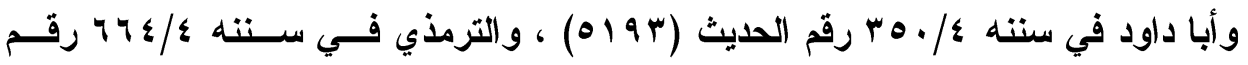

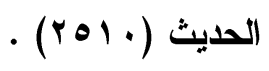

ـ وقد ورد برواية " لا تلخلون الجنة حتى تؤمنوا " في صديح مســم /ع v رقـم العـديث

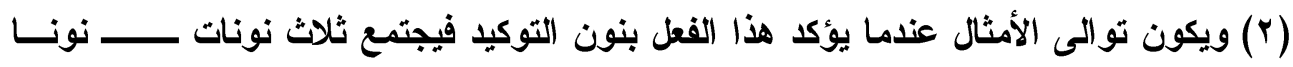

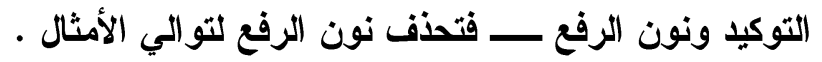

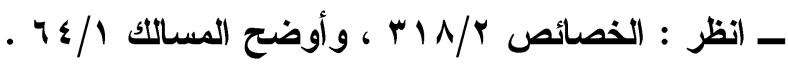

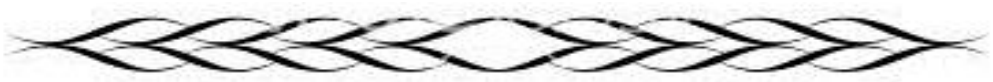




\section{الترقير الدوله}

ISSN 2356-9050
Trit

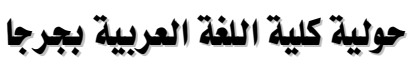
مجلة علمية محكمة

المعروفة ؛ لأنّ " لا " هنا نافية لا ناهية ، والنافية لا تعمل ، ولكن حــف

النون هنا جاء لأجل المشاكلة والازدواج للفظي " تؤمنوا " ، و" تحابوا " (1).

وقا يحتمل حذف النون من الفعل هنا مع " لا " النافية قولين :

اـ أن حذف النون لمجرد التخفيف وهو ثابت في الكلام الفصيح (ז)،

نثرا ونظما ، كما في قوله ـ صلى الله عليه وسلم ـ : " كما تكونوا يــولى

عليكم " (") (")

وفي الحديث السابق قال النووي : " " وكَا تُؤمْنُوا " بحذف النُّون من

آخره وهي لغة معروفة صحيحة " (ع)

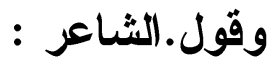

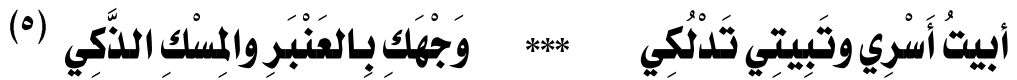

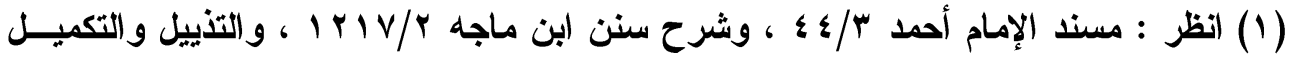

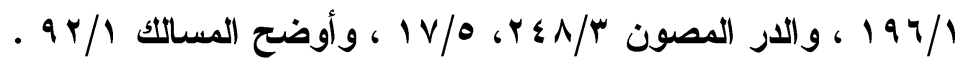

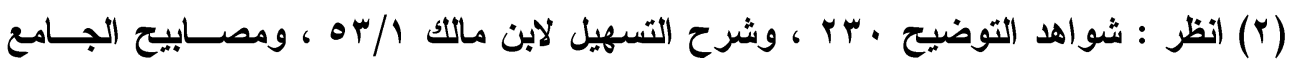
$. r \wedge q / \Lambda$

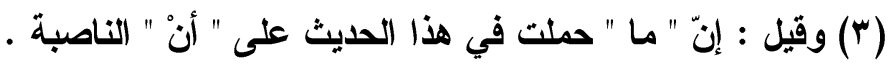

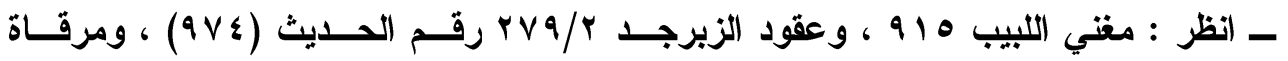

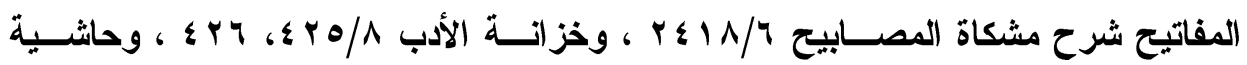

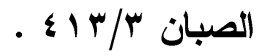

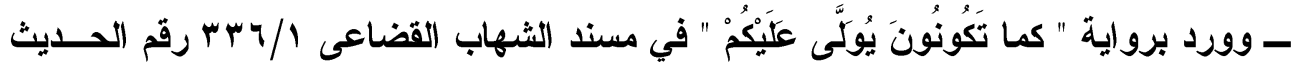
(\&VV)

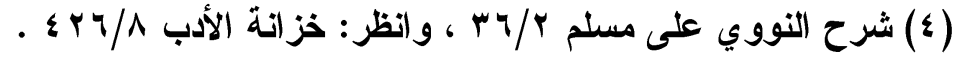
(0) من الرجز ، مجهول القائل

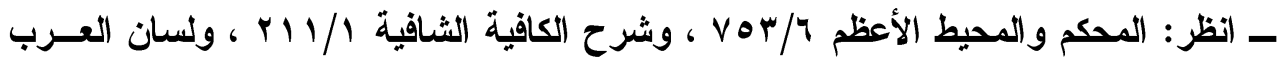

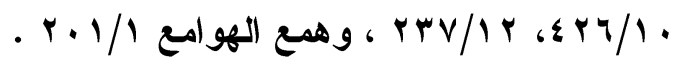


والأصل " تبيتين " و " تدلكين " حذف النونين دون ناصــب ولا جـازم

ولا يقاس على ذلك في الاختيار (1)

r) أن يكون حذف النون اضطر ارًا ؛ لئلا يلتقي ساكنان ـ (r)

\section{تمقتمبـب}

يبدو مما سبق أن مجيء الفعلين " تلخلوا " و " تؤمنوا " في هــذا

الحديث وإن كان مخالفًا للقياس - بحذف نون الأفعال الخمســـة منـــه دون وجه - وقياسه " تلاخلون " و " تؤمنون " إنما جاء لأجل المشاكلة .

وما عللوا بـه من أسباب أخرى لحذفها إنمـــا هــو شــيع قليـلـل ،

والأولى عدم القياس عليه الكلام الفصيح .

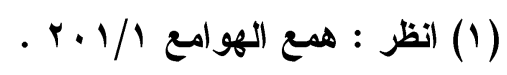

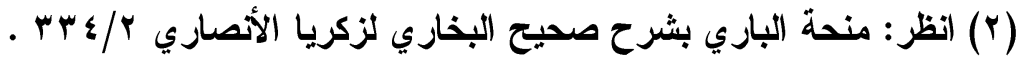

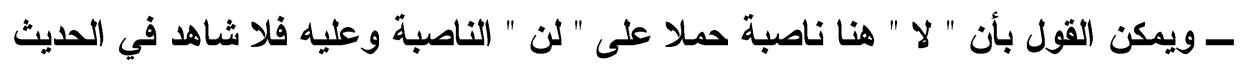




\section{الترقيم الدولخ}

ISSN 2356-9050
OR حولية كلية اللفة العربية بجرجا مجلة علمية محكمة

\section{استعممال (هما الإوصولة لاعماقل للامشاكلة}

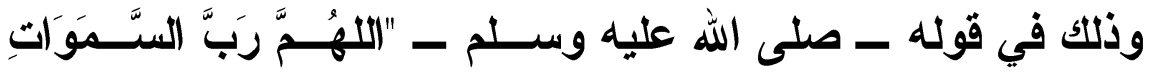

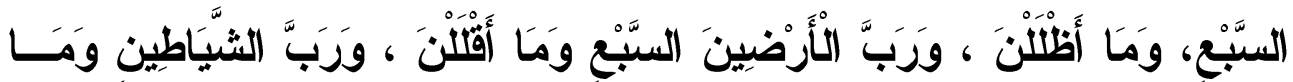

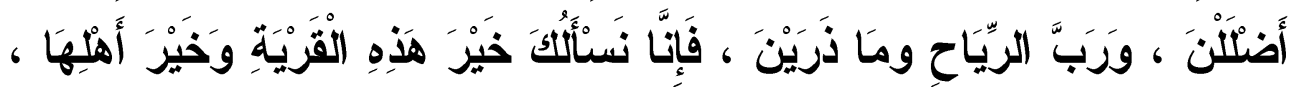

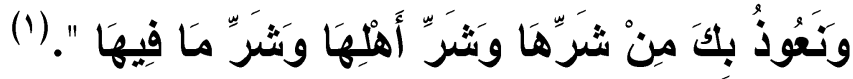

حيث جاء قوله " ما أَضْلَنْ "في الحديث الشريف مخالفًا للاقيــاس ؛

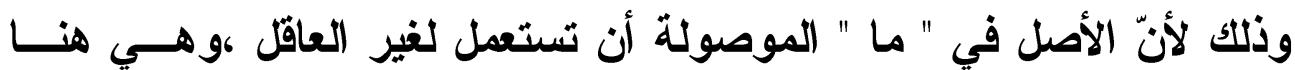

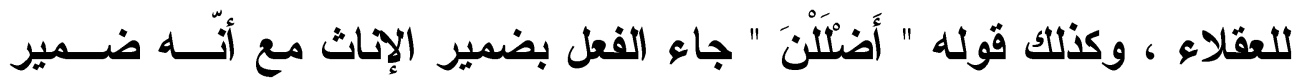
الثياطين - ضمير الأكور - وكان القياس أن يقــال : " ومــن أَضْـــواء " ؛

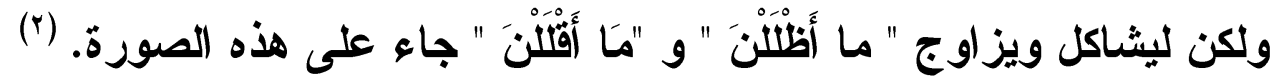
وبيان ذلك فيما بأتي : تنقسم هذه المسأكة إلى شقين وهما : اــ " مَا " ، و" مَنْ " من الأسماء الموصولة التَي تستعمل بمعنى " الــــي " و " التي وتثيتهما وجمعهما .

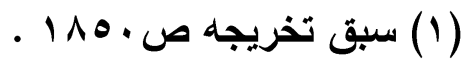

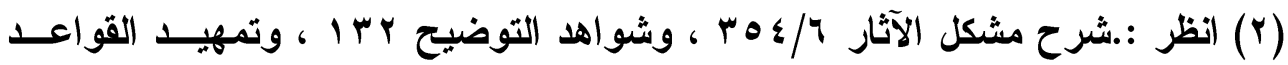

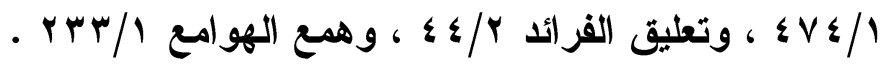




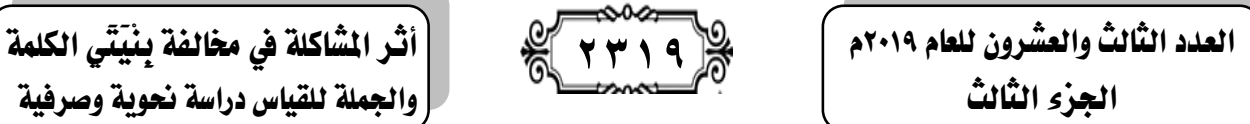

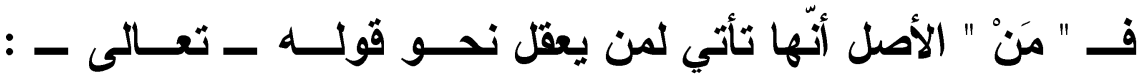

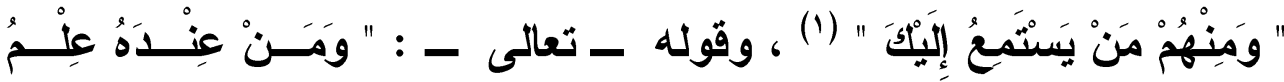

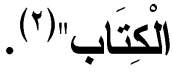

وقد تأتي لمن لا يعقل لاقتر انه بمن يعقل نحو قوله - تعـالى - :

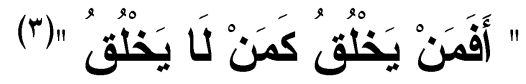

وأمـا " مَا " الموصولة فالأصل أن تأتي لمن لا يعقل نــــو قولـــهـ ــ

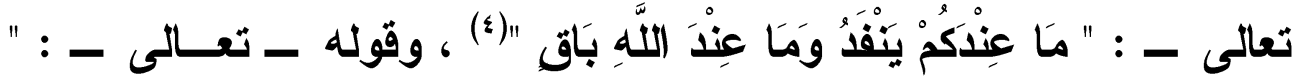

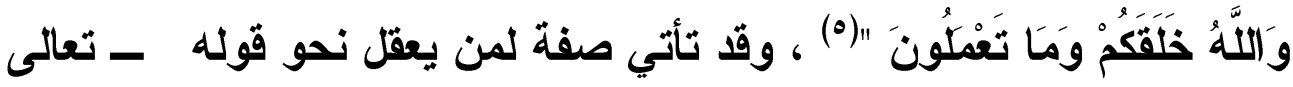

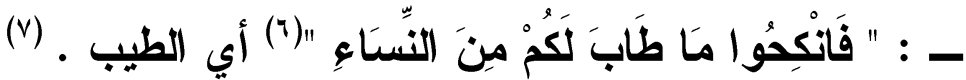

r- ضمير الإنـاث ، فنون النسوة ضــمير متصــل يتصــل بالفعـلـ

الماضي والمضارع والأمر ليدل على أنّ الفاعل جمع من النساء .

وما جاء في الحديث من قوله " ومَا أَضْلَنْ " مخالف للقياس ؛ لأنّ " مَا " جاعت هنا للعاقل ، و" أَضْلَنْنَ " فالقياس أن يقال : " أضلوا " بــالواو

$$
\begin{aligned}
& \text { (1) من الآية (0) في سورة " الأنعام " ، ومن الآية (1 1).في سورة " محمد " . }
\end{aligned}
$$

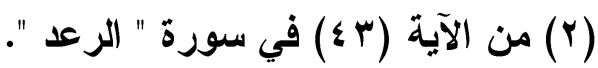

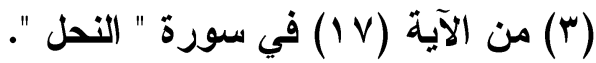

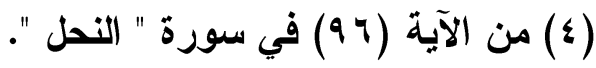

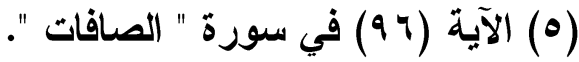

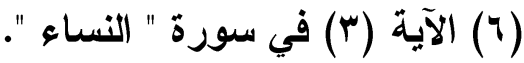

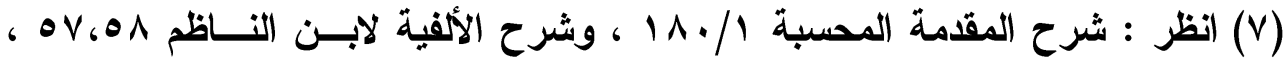

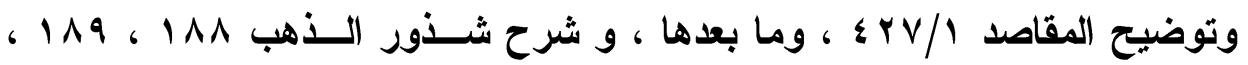

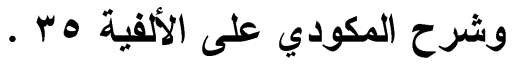




\section{الترقير الدولم \\ ISSN 2356-9050}

المناسبة لضمير الثياطين ، و إنما جاءت بالنون ـ ضمير الإناث ـ لمشاكلة

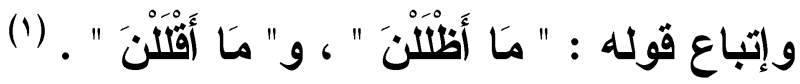

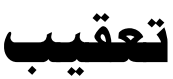

يتضح مما سبق أن مجيء " ومَا أَضْلَّنَ " في هذا الحديث باستعمال

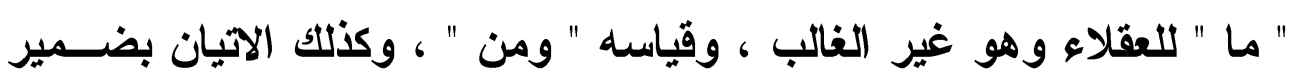

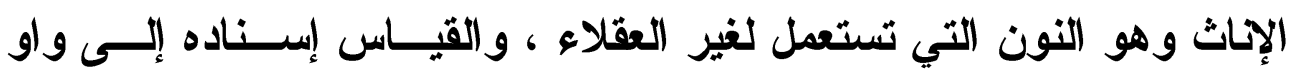

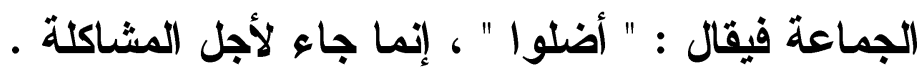

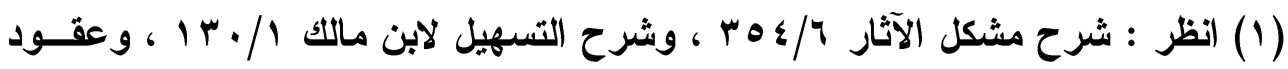

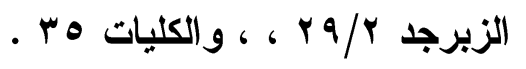




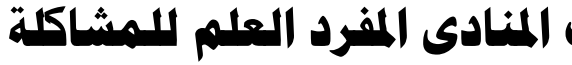

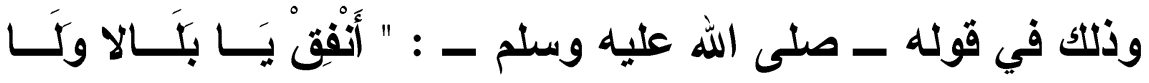

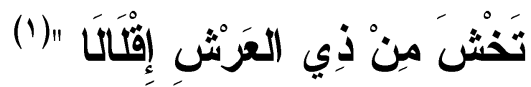

حيث استخل النحويون والبلاغيون بهذه الرواية على أن قولـــهـ : "

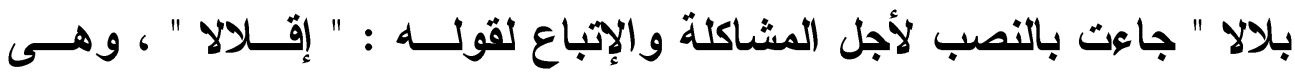

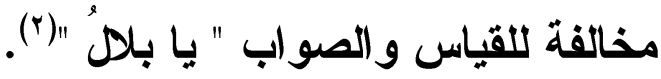
وييان ذلك فيما بأتي : ينقسم المنادي إلى قسمين :

أحسدهـها : المنادى المعرب ، وهو المضاف نحو : " يــا عبـــَ الله

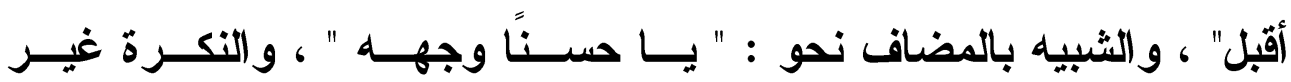
المقصودة نحو : " يا سائقا التزم بقواعد المرور "، فالمنادى هنا منصوب .

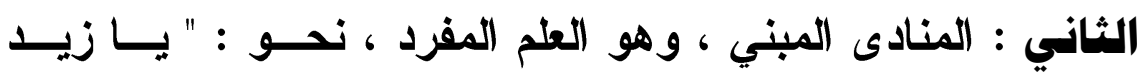

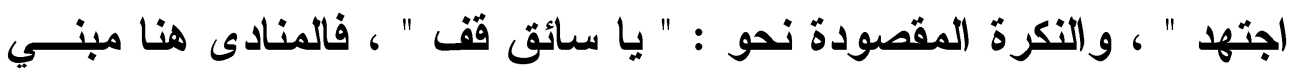

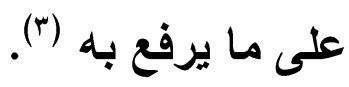

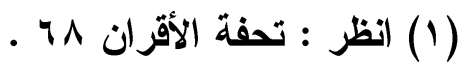

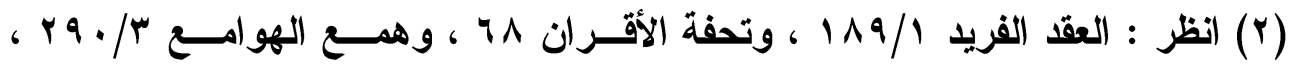

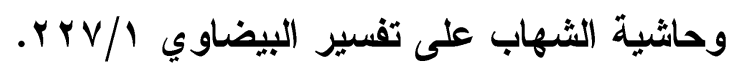

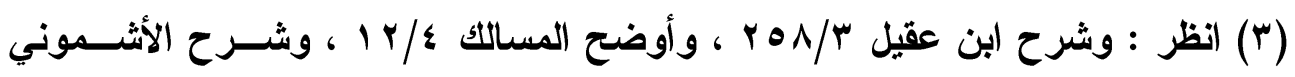
r r, Tr/T 


\section{الترقيم الدولخ}

ISSN 2356-9050

\section{PrPr

حولية كلية اللفة العربية بجرجا

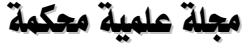

الأصل في المنادى الإعراب ، و إنما بنى لوقوعه موقع الكاف فــي

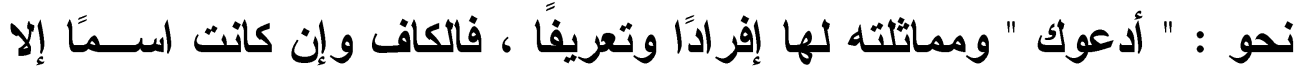

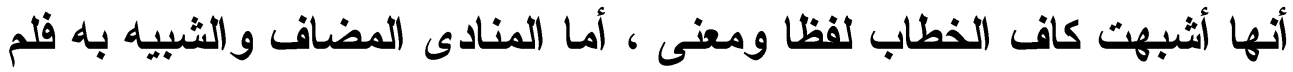
يماثل الكاف الاسمية في الإفراد ، وأما النكرة غير المقصودة فلم تماثلها في التعريف (') - (1) وبالرجوع إلى كتب الأحاديث لم أجد رواية النصب وإنما ورد "بلال"

بالرفع (r)

أما رواية النصب " بلالا " فقد ذكرها الهيثمي في المقصد العلي في

زوائد أبي يعلي الموصلي (־)

وقد رجعت إلى مسند الموصلي فوجدت الرواية بالضم " بلالُ "

يظهز مما سبق أن الرواية التي استثهدوا بها في هـــا الحسديث

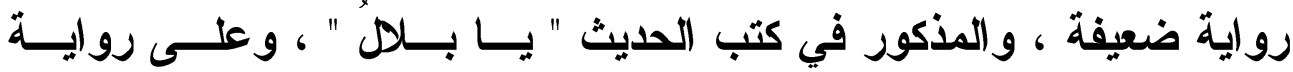
النحويين ، وبعض شراح الحديث له بالنصب إنما ياخل في باب المشاكلة .

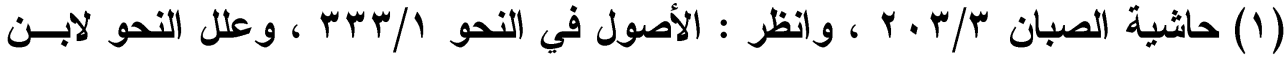

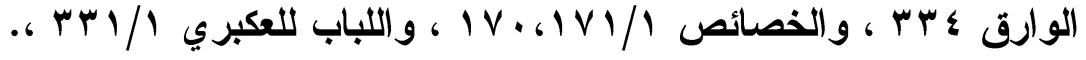

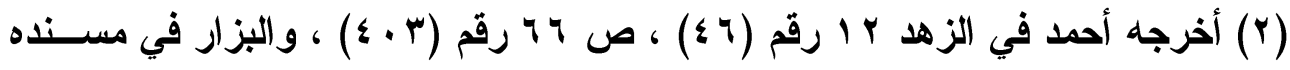

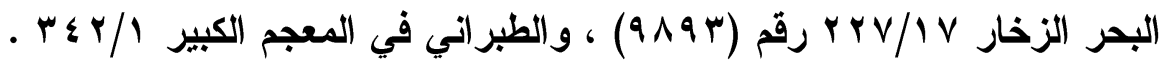

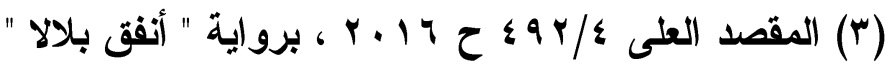




\section{الإتباع في العركة للامشاكلة}

وذلتك في قصة الصحابي الأي روى عن النبي - صــلـى الله عليــه

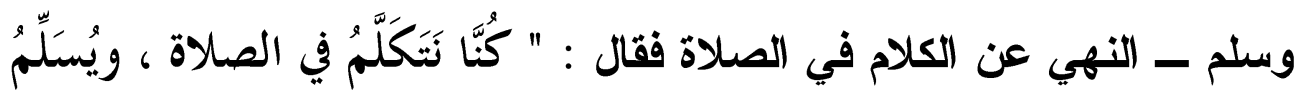

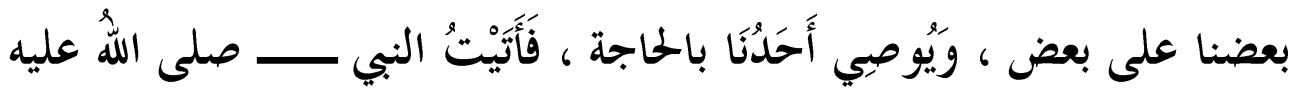

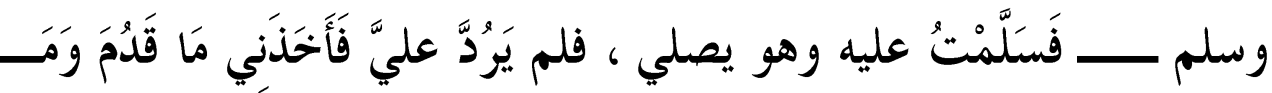

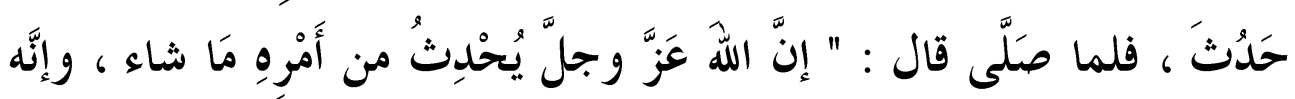

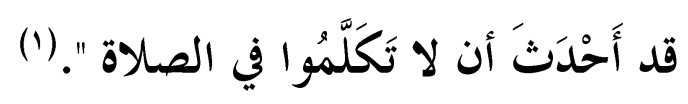

حيث استعملت كلمة " حَدُث " بضم الال وكان القياس أن يقـال : " حََثَ" بقتح الدال وهو فعل ثُلاتي على وزن " فَعَل " ، وقا جاعت على غيــر

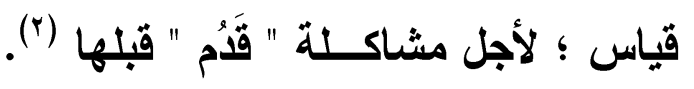
ويبـن ذلك فيما بأتي :

من أوزان الفعل الثثلاثي المجرد " فَعُل " - بـتِح فضم ـ ولا يـأتي

الفعل معها إلا لازما ، وأقعال هذا الوزن تدل على الطبائع أو السجايا ـ (ץ)

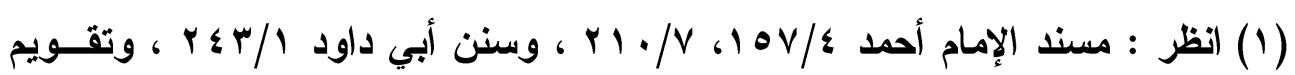
اللسان 99 .

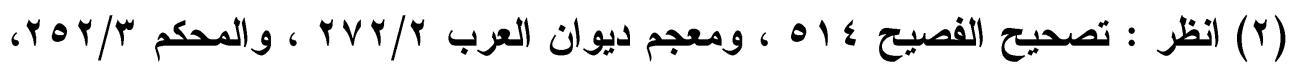

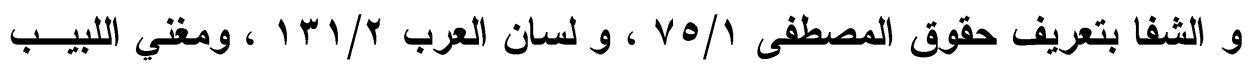

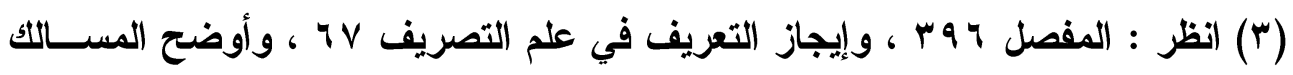
$.1996191 / \mu$ 
وقد استعمل " حَدُث " في هذا الحديث ـ بضم الدال على وزن " فَعْل

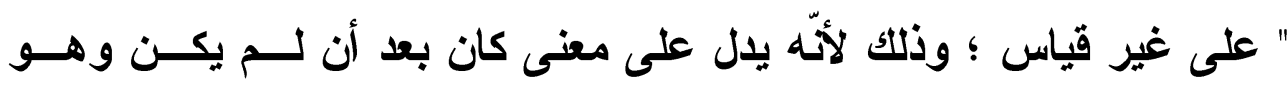

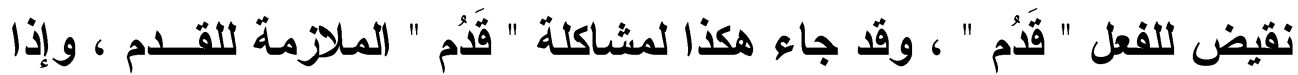

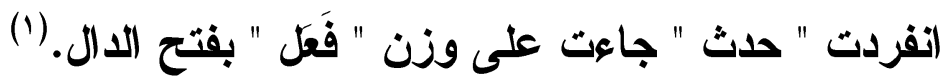

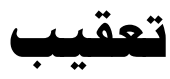

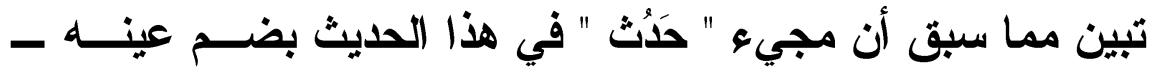

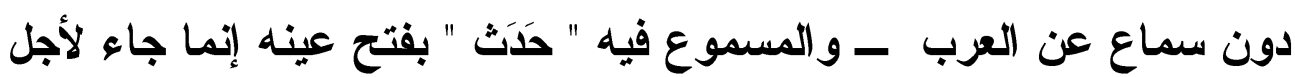

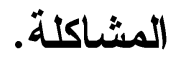

وما قيل من أنه مسموع عن العرب فهو لـ يسمع إلا ميع " قَدُم " ، وبهذا لا يخرج عن كونه للمشاكلة .

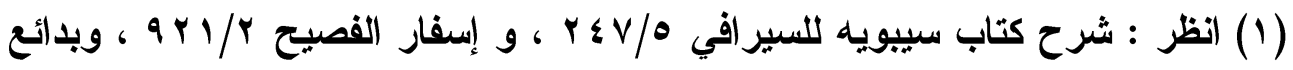

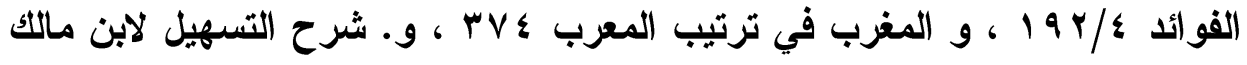

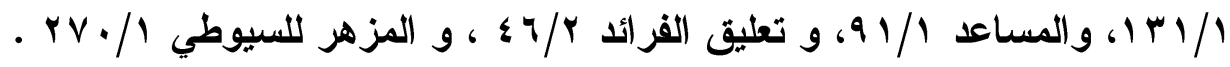




\begin{tabular}{|c|c|c|}
\hline | أثر الشاكلة في مخالفة بنيتَتي الكلمة & ? & العدد الثالث والعشرون للعام 19. الجزء الثالث \\
\hline
\end{tabular}

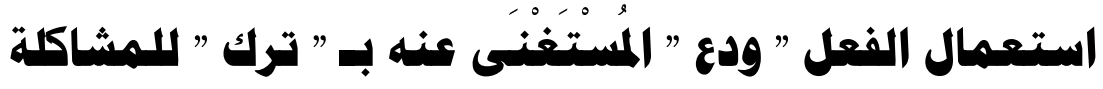

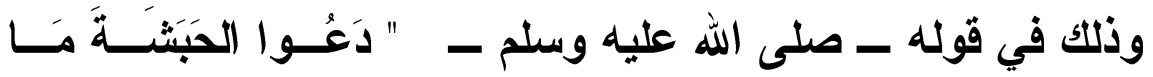

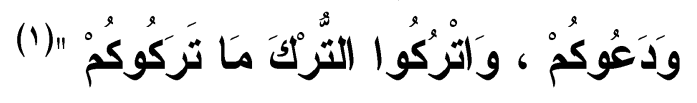

حيث جاء ماضي الفعل " وَدَع " في الحديث الشريف ، وهو شاذ في الاستعمال وكان القياس أن بستخدم الفعل " ترك "

ويبيان ذللك فيما بأتي :

الفعل " وَدَعَ " معناه " تَرَكََ " ، وقد استغتى النحويون غالبـــا عـنْ

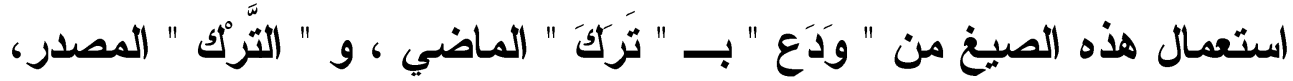
و " تارك " اسم الفاعل ، و" مترول " اسم المفعول .

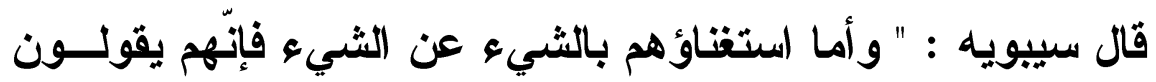

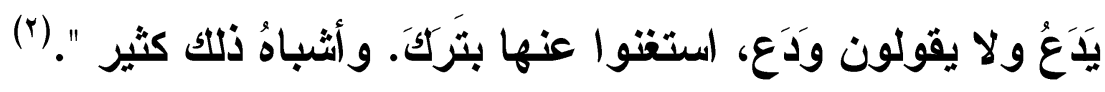

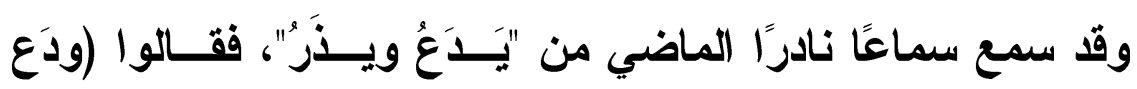

ووذَر) ، بوزن (وضع) ، إلا أن ذلاك شاذ في الاستعمال ؛ لأنّ العرب كأهم إلا قليلا منهم، قد أماتوا هذا الماضي من لغاتهم. وليس المعنى أنهم لم يتكلَّموا

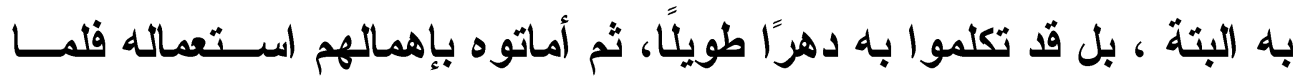

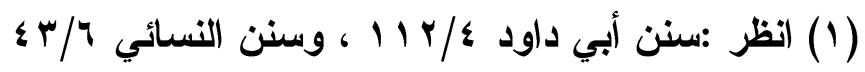

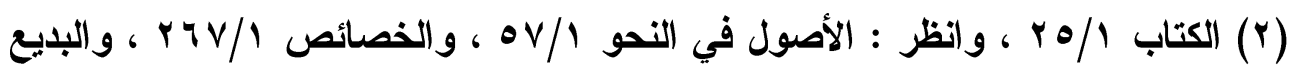

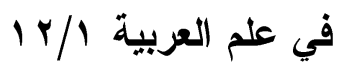




\section{الترقير الدولخ}

ISSN 2356-9050
Trit
حولية كلية اللفة العربية بجرجا

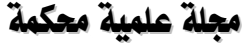

جمع العلماء ما وصل إليهم من لغات العرب وجدوه مماتًا ، إلا ما سمع منه

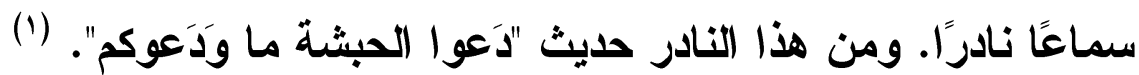
ومن هذا النادر قراعة أبي حيوة ، وابن أبي عبلة ، وعـروة بــن

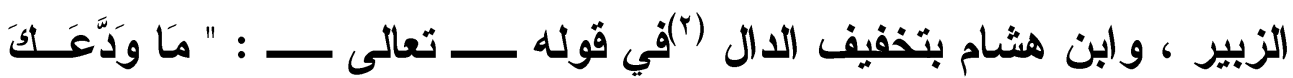

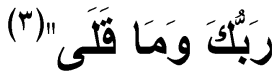
ومنه ما روى في بعض الأثُعار كقول أبي الأسود الاؤلي :

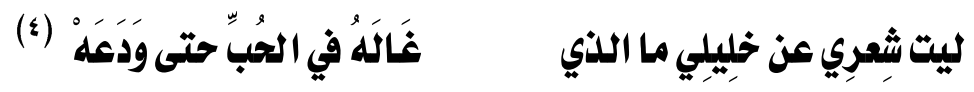

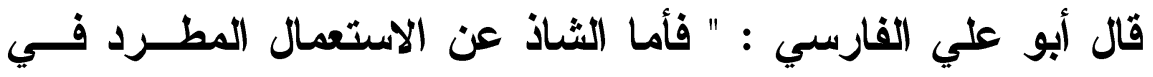
القياس فكما في ( يدع ) ، و ( يذر ) ، فماضي هذا لا لا يمنع منـــه القيــاس.

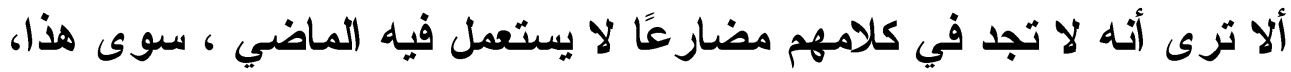

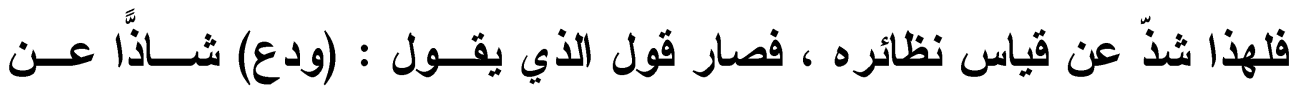

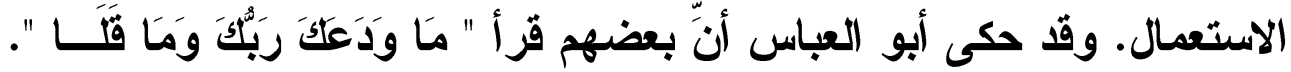

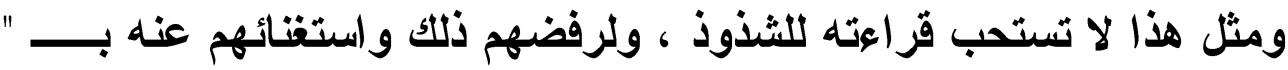

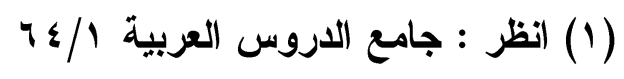

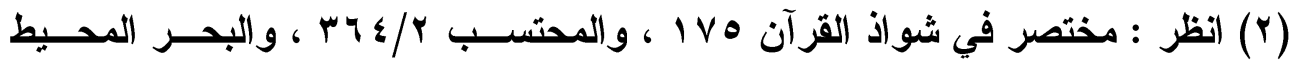
.

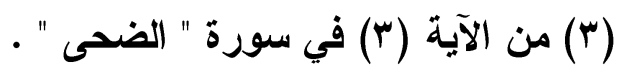

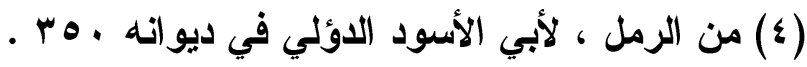

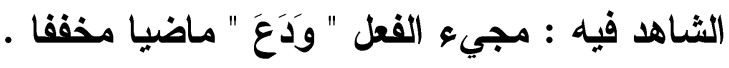

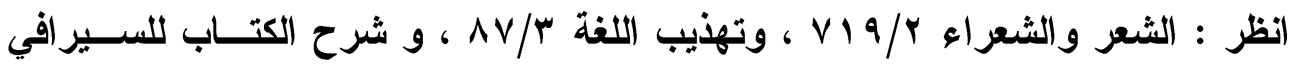

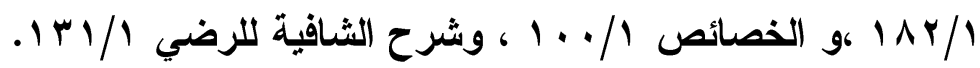

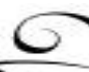




\section{أثر الششكلة في مخالفة بنيتيتي الكلمة \\ والجملة للقياس دراسة نحوية وصرفية

تركه " ، وكما رفض مثال الماضي منه ، فكذلك رفـض المصـــر ، واســم

(الفاعل." . (الفاع)

فقد أمات العرب ماضي " يدع " واستغتوا عنه بـ " تَركََّ " ، وعليه فهناك من قال بأنّ ما جاء في الحديث من " ودعوكم " ، كان لأجل المشاكلة

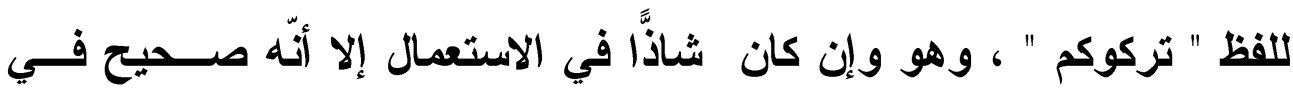

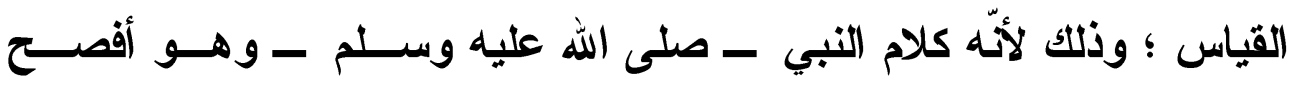

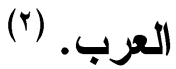

وهناك من قال بأنّ لفظ الحديث " ما وادعوكم " أي سالموكم فسقط

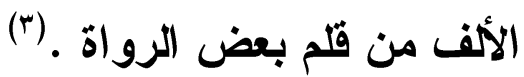

ولا داعي لهذا القول فقد ورد في قراعة التخفيف في قوله ـ تعالى

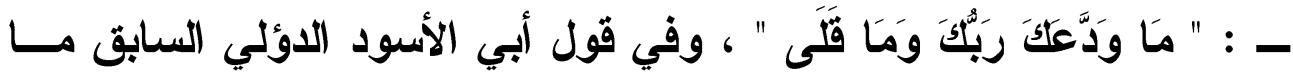
يؤيد وروده ولو على الثواذ .

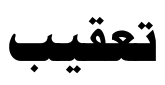

تبين مما سبق أن مجيء ماضي الفعل " ودَعَع " في هذا الحديث وإن كان قد ندر سماعه عن العرب إنما جاء لأجل المشاكلة . وما قيل من أوجه أخرى فيكون قد عدل عــن الاحتمـالات الأكثــر شهرة إلى الاحتمالات الأقل شهرة لأجل المشاكلة .

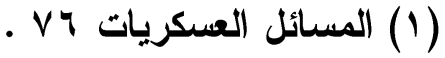

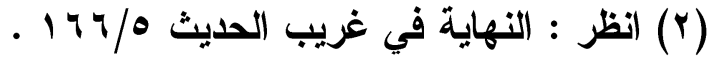

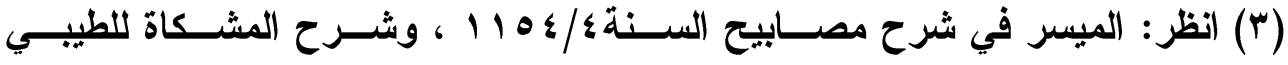

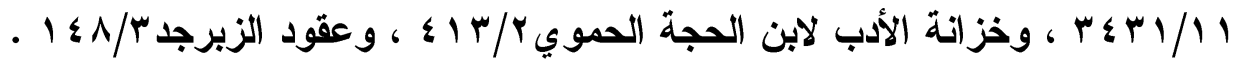

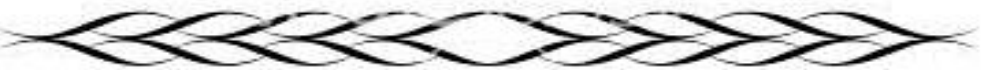




\section{الترقير الدولم \\ ISSN 2356-9050}

\section{ضم حرف الضارع هن الفمل الثلاثي للامشاكلة}

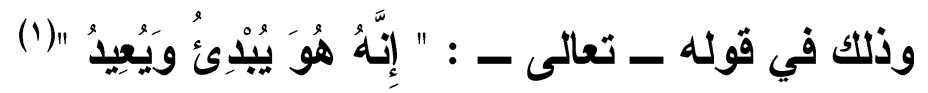

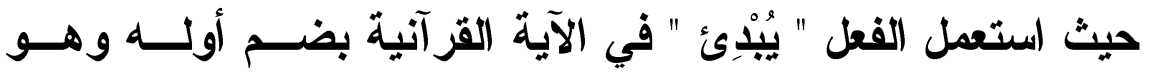

مأخوذ من " بَدَأ " الثتلاثي فجاء على غير قياس لمشاكلة الفعـل " يُعِيـــ " ، و القياس أن يقال في مضارعه " يَبْأ " بقتح أوله.

\section{ويبان ذللك فيما بأتّي :}

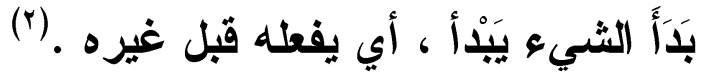

والفعل " بـأ " فعل ثُلاتي ، وقياس المضارع منهه " يَبِأ " بقتح أوله

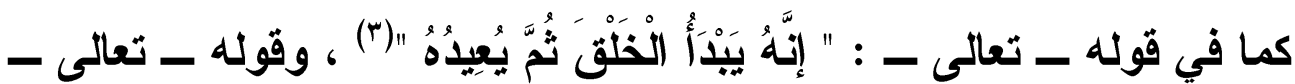

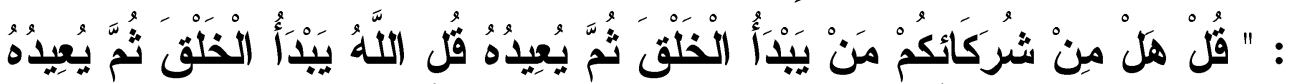

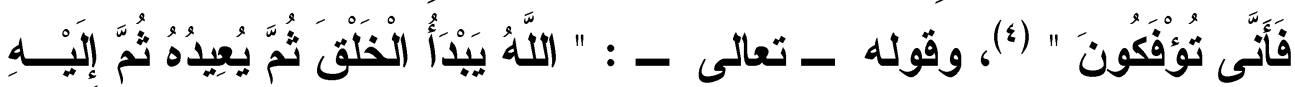

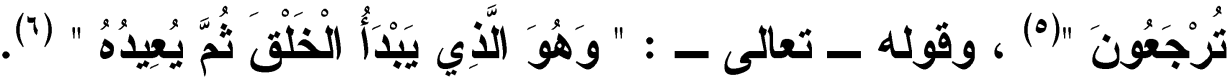
وما جاء في الآية مجال البحث من قوله " يُبدئ " بضم أوله ، على

غير قياس ؛ إنما جاء لأجل مشاكلة وإتباع قوله " يُعيد " (v)

$$
\begin{aligned}
& \text { (1) الآية (ب ا) في سورة " البروج " . }
\end{aligned}
$$

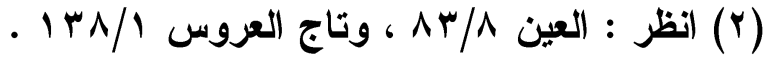

$$
\begin{aligned}
& \text { (ז) من الآية (צ) في سورة " يونس ". }
\end{aligned}
$$

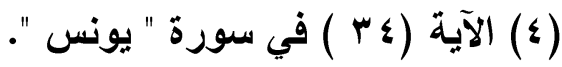

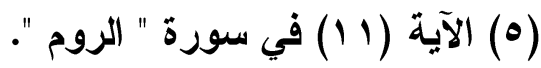

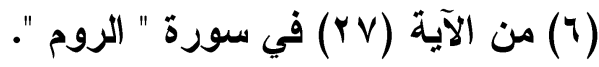

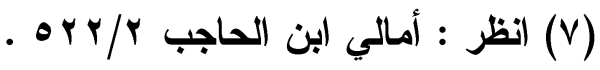


وما جاء من آيات استعمل فيها اللفظان ـ "يبـــئ " بضـــم اليــاء

وفتحها ـ فإنما جاعت لأجل المشاكلة والإتباع ، كما في قوله ـ تعالى ـ ـ

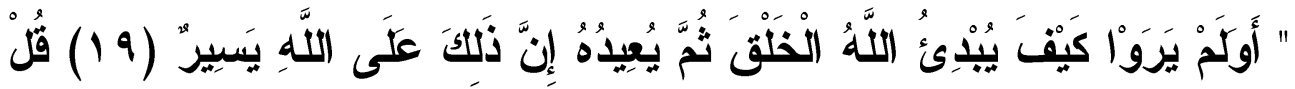

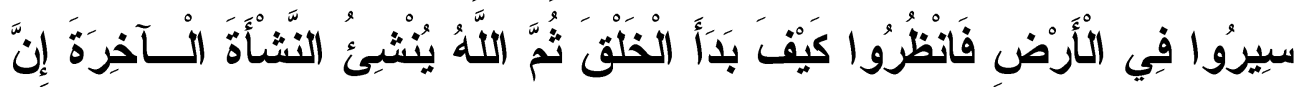

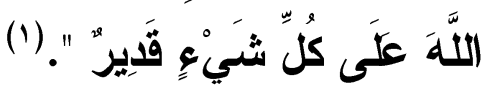
ومما يرجح أنتها من الفعل " بَََأ "، أن الآية ذُكر فيها الفعل " يُبِْئي"،

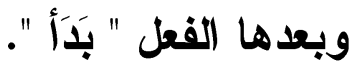
وهنالك من قال : إنّّ الفعل هنا جاء من الفعل الرباعي " أَبَبًَأ "فيكون

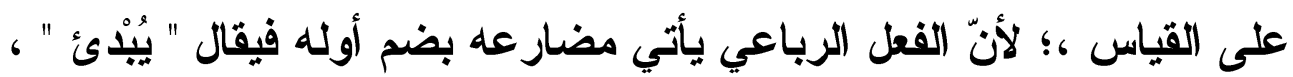
وعليه لا شاهد على المشاكلة (؟).

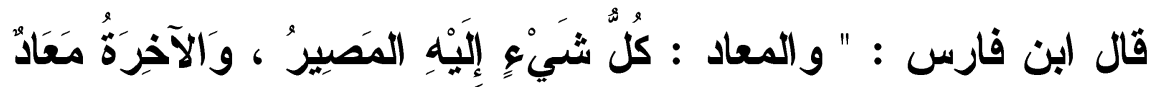

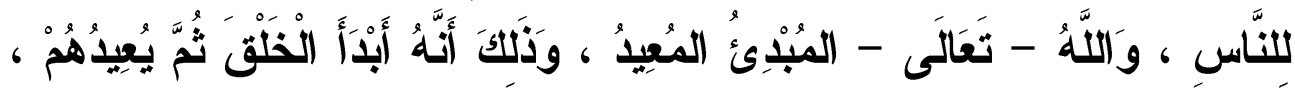

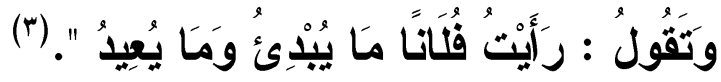

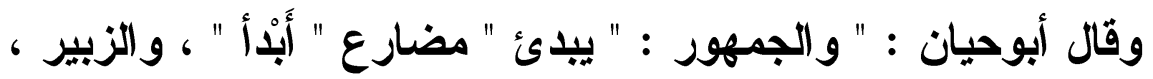

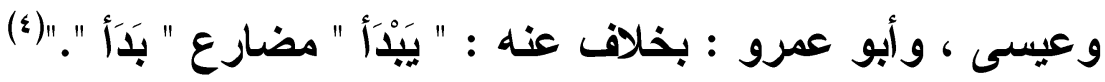

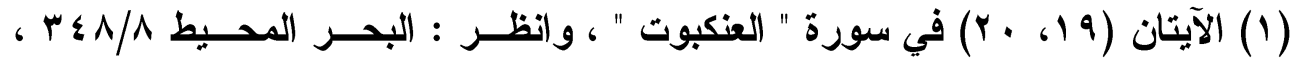

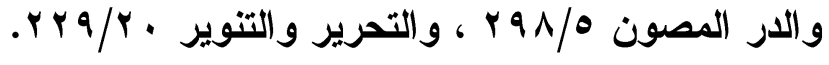

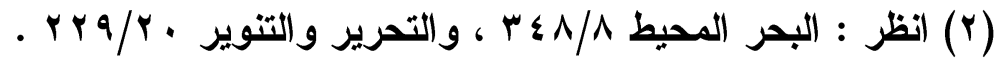

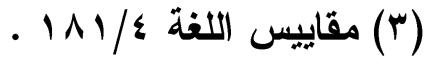

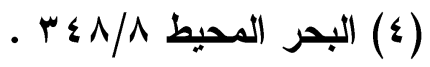




\section{الترقير الدولم ISSN 2356-9050}

يبذو مما سبق أن مجيء الفعل " يُبْدئ " في هــذه الآيــة مخالفــا

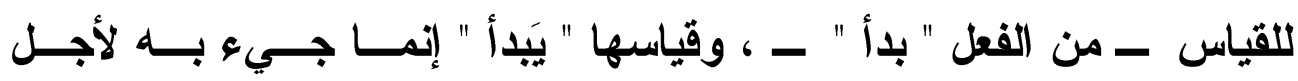

المشاكلة .

وما ذهب إليه بعضهم من أن هناك فعل رباعي " أبدا " فيحتاج إلى

سند قوي من أقوال العرب . 


\section{تعدية الفمل على فير ما سمبِع في تعديته للامشاكلة}

وذلك في قول العرب : " هَنَّأَبِي الطعامُ ومَرَّأَبِي "(1)

حيث استعمل الفعل " مَرََّتِّي " في قول العرب متعديًا بالتضعيف وهو

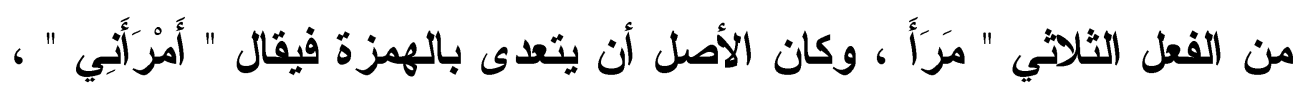
و إنما جاء بالتضعيف لمشاكلة " هَنَّنَّي " .

\section{ويبيان ذلك فيما بأتي :}

$$
\text { من أوزان الفعل الثلاثي المزيا بحرف : }
$$

ا- " أفعل " ، ومن معانيها التعدية نحو : " أخرجت زيدًا " .

r - " فعّل " ، ومن معانيها التعدية نحو : " فرّحت زيدًا " .

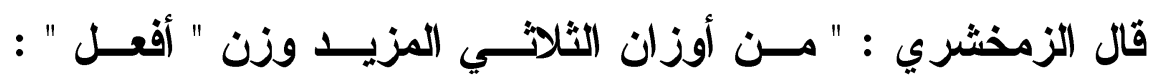
و" أفعل " للتعدية نحو : " أجلسته ، وأمكنته."....

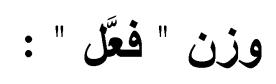

و" فعّل " يؤاخي " أفعل " في التعدية نحو : " فرحته ، وغرمته "(r) ومعنى التعدية هو ما ينطبق على " أَمْرَأَّي " في قول العرب السابق

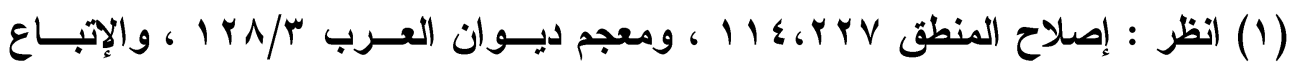

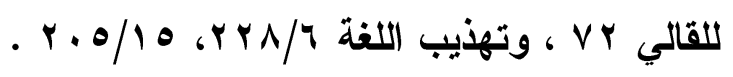

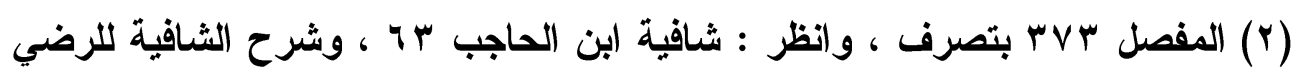
إ 


\section{الترقير الدولخ}

ISSN 2356-9050
Q
حولية كلية اللفة العربية بجرجا مجلة علمية محكمة

فالفعل " مَرَّنَي " من الفعل " مَرَاً " ثُلاثي مزيد بحرف ، وهو فعـل

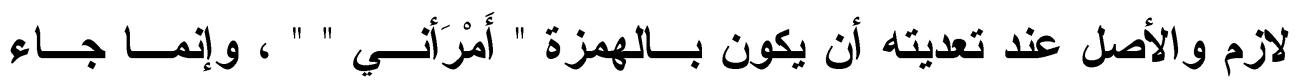

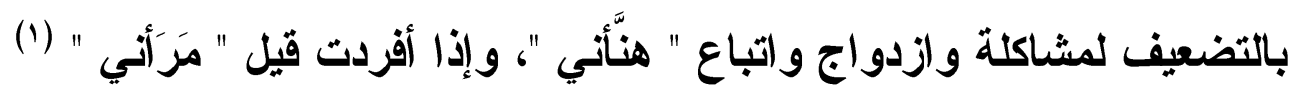
وقد حكى أهل اللفة " مرّأني " ، و" أمْزَي " لغتين قال صاحب المصباح المنير : " ويقال أيضا : هنّأني الطعام ومرّأني

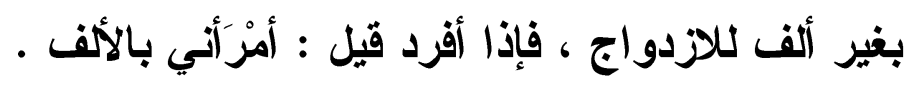

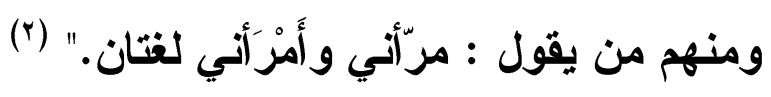

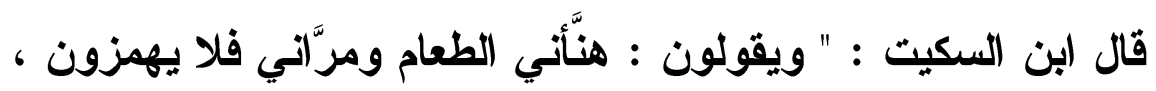

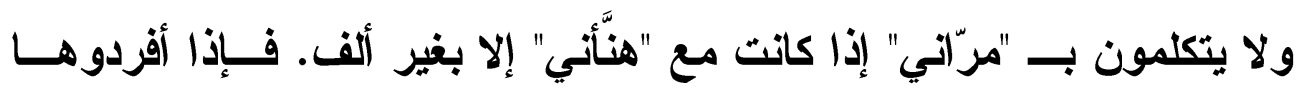

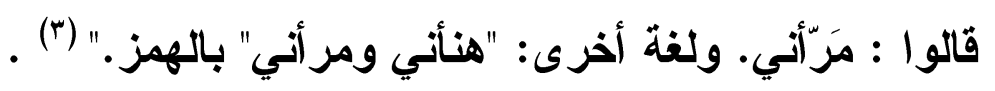
تعقير يبدو مما سبق أن مجيء " مَرَّأنبي " في هذا القول - بتضعيف عينه

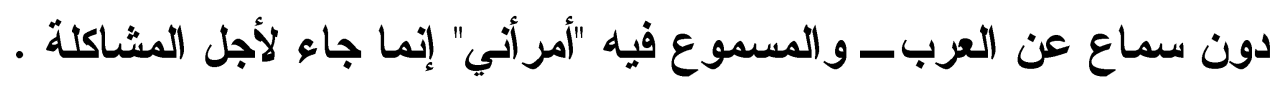
وما قيل من أنه مسموع عن العرب فهو لم يسمع إلا مع "هنأني" ، وبهذا لا يخرج عن كونه للمشاكلة .

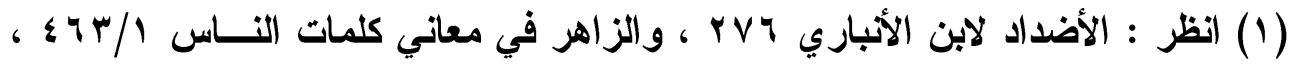

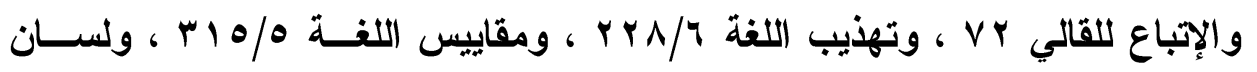

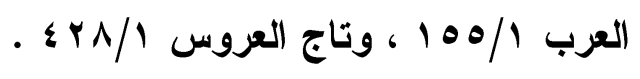

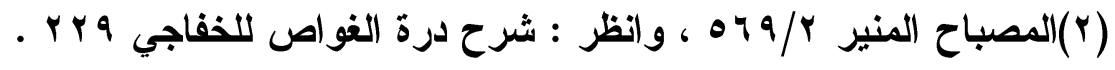

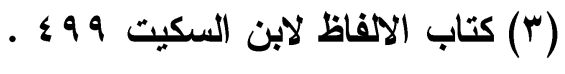



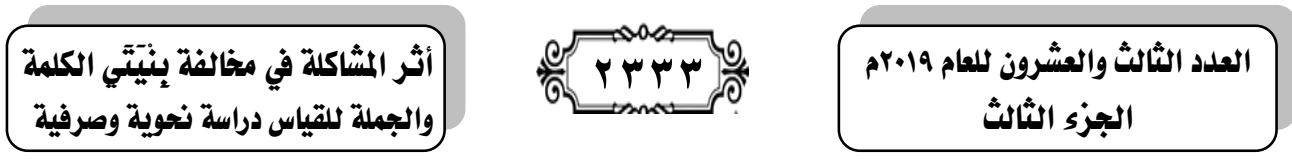

\section{توكيد المضارع على غير قياس للمشاكلة}

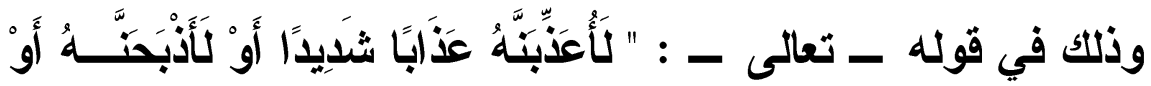

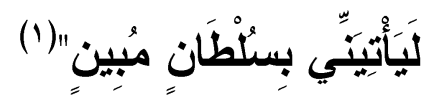

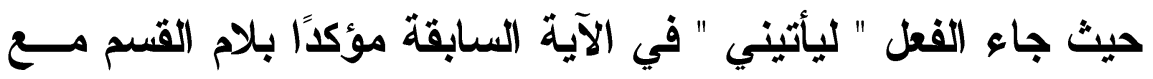

أنّ المعنى يأباه ، و إنما جاء هكذا لمشاكلة الفعلين " لأعذبنه "، و" لأذبحنه" .

وييان ذلك فيما بأتي :

من حروف القسم " اللام " وتسمى لام القسم ، وتأتي هــــه الــلام

لتوكيد الجملة المقسم عليها ، وتكون مع الفعل المستقبل لازمة لنوني التأكيد

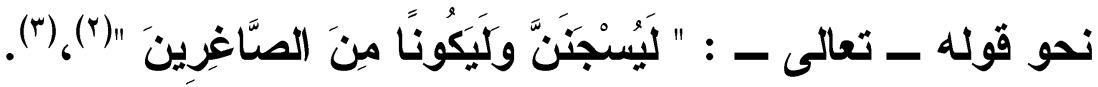

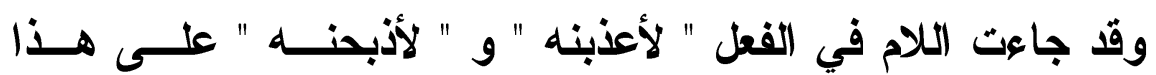

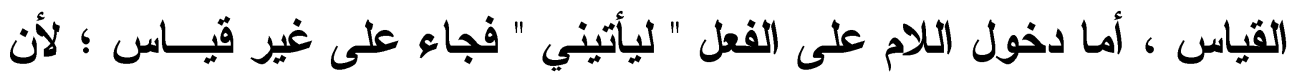

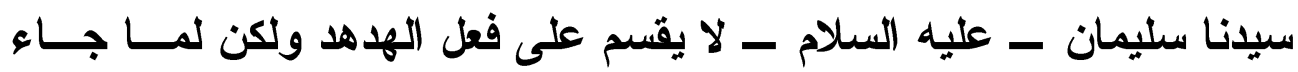

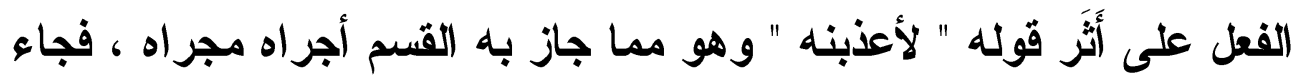

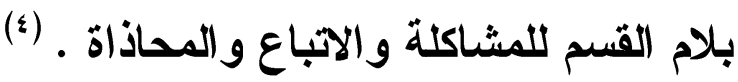

$$
\begin{aligned}
& \text { (1) الآية (1/r) في سورة " النمل " . }
\end{aligned}
$$

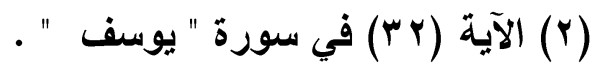

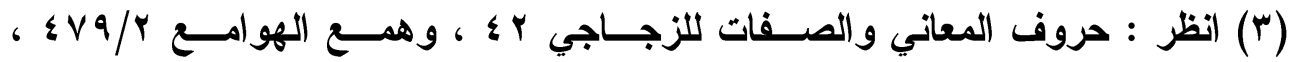

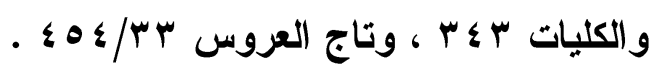

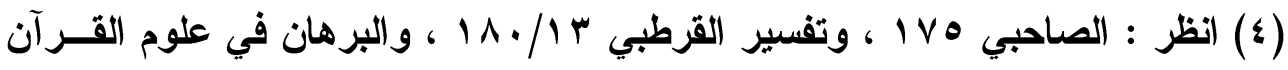

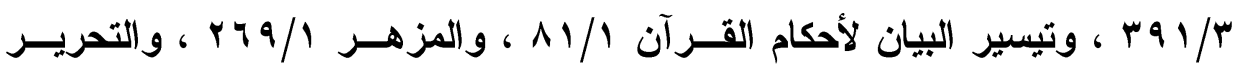

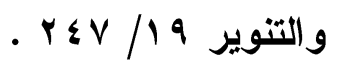




\section{الترقيم الدولخ}

ISSN 2356-9050

\section{Pris}

حولية كلية اللفة العربية بجرجا مجية مجلة علمية محكمة

وجاء في التحرير والتتوير توجيه آخر وهو أن جملــة " ليــأتيني

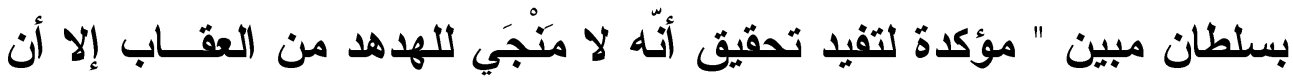
يأتي بحجة تبرر تغيبه ؛ وذلك لأن سياق الجملة يُفيد أنّ مضمونها - الإتيان

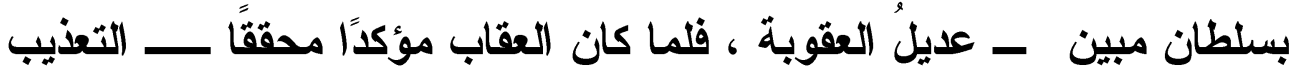

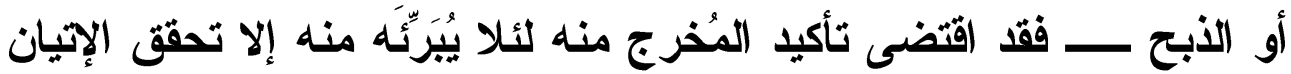

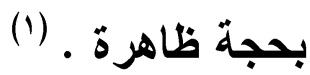

تهقيـبـ

تبين مما سبق أن ثوكيد الفعل " ليأتيني " في هذه الآية وإن كــان مخالفًا للقياس ـ لتوكيده بالكلام دون وجه ــ وقياسه " يأتثيني " إنمــا جــاء

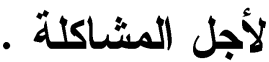

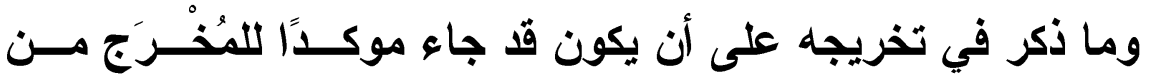

العقاب كما أكد العقاب ، فيكون تأكيا العديل كتأكيد معادله ، فهــو أيضـــا لا يخرج عن كونهـ جاء لأجل المشاكلة .

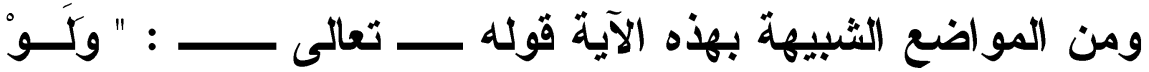

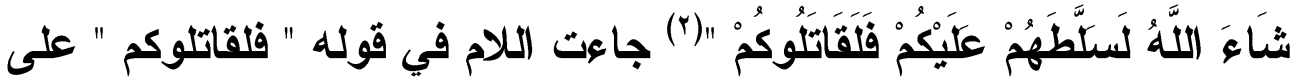
غير قياس ؛ وذللك لأجل المشاكلة والإباع لقوله " لسلطهم " جواب " لو " ، وإلا فالمعنى : " لسلطهم عليكم فقاتلوكم " (r).

(1) انظر : التحرير والتنوير 9 (1)

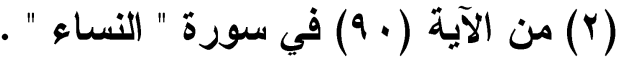

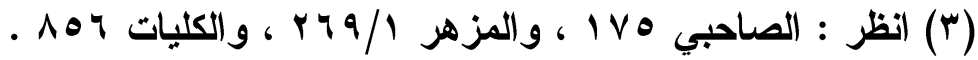




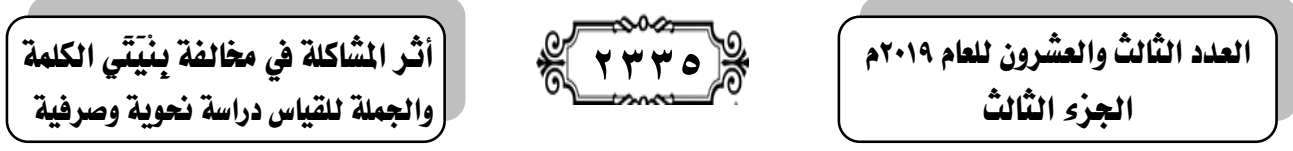

هجيs اسم الفاعل هن الرباعي على وزن " فاعل " للمشاكلة"

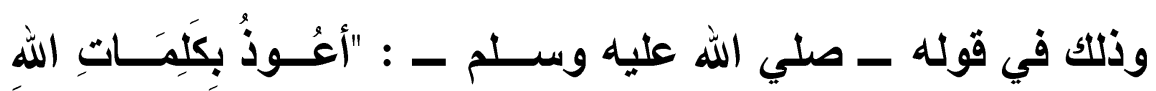

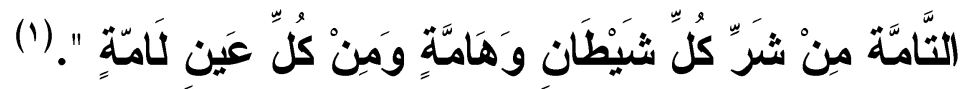

حيث جاهت كلمة "لامة " في الحديث الثريف مخالفة للقياس ؛ لأنّ أصل الفعل " أَلَّمَّ" وهو رباعي ، و والقياس أن يأتي اسم الفاعل منـــه بإبــــال

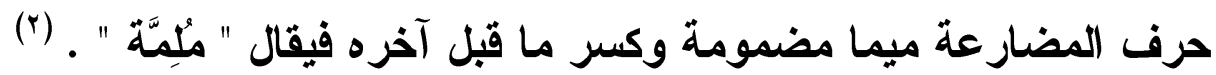
وييان ذلك فيما بأتي :

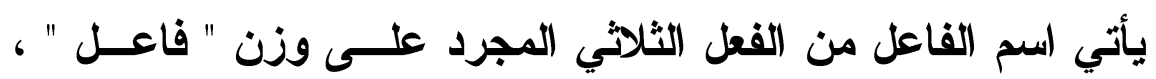
ومن غير الثلاثي المجرد بلفظ مضارعه مع إبدال حرف المضــارعة ميمَّا

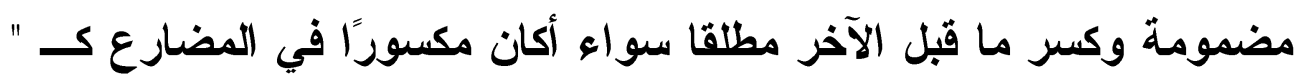

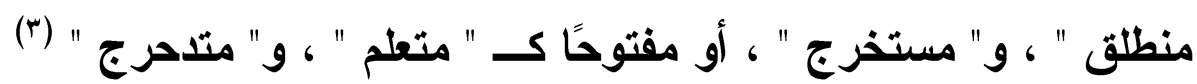
وتحتمل كلمة " مُمََّّة " ثلاثية أوجه :

اــ أن تكون قد جاعت على ظاهرها بمعني " جَامِعَة للشر على المعيـون ،

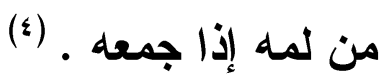

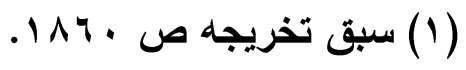

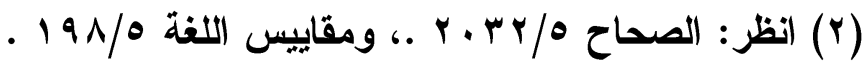

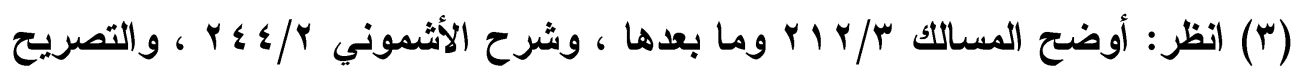

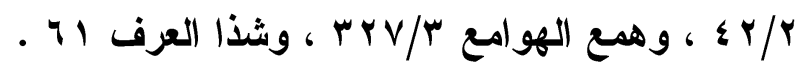

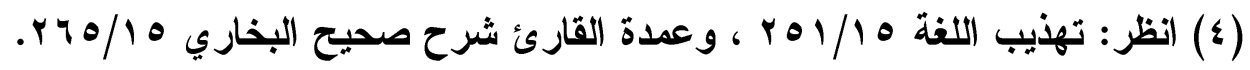




\section{الترقير الدولخ}

ISSN 2356-9050
Trmy
حولية كلية اللفة العربية بجرجا مجلة علمية محكمة

r- أن تكون قد جاعت مخالفة للقياس ؛ لأجـل المشاكلة والإبـــاع لكلمــة

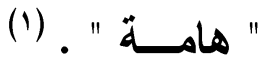

rــ أن يكون معناها في الحديث " ذات لمم ". (r)

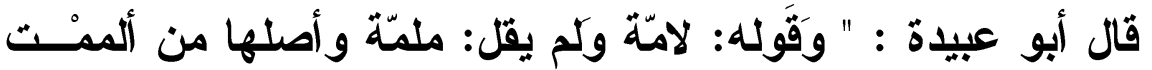

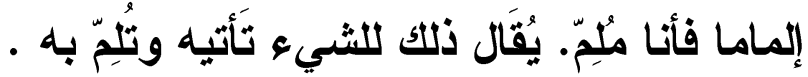

وَقا يكون هذا من غير وَجه منها أَن لا تُريد طريث الفعل ولكن تريد

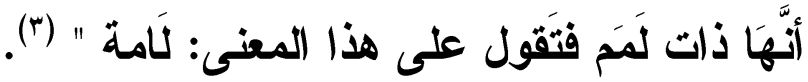

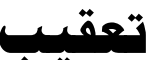

يبدو مما سبق.أن مجيع " لامة " في هذا الحديث على " فاعلة " ،

وقياسها " ملمة " إنما جاء لأجل المشاكلة .

وما قيل من أنهّا ترجع إلى أصول تجعلها قياسية فهذا لا يخلو مسن

كونه محسن لفظي من المحسنات البديعية ألا وهو الجناس الناقص .

(1) انظر : شرح المشكاة للطيبي \&/ / I I ، و وعدة القارئ شرح صـــيح البخــاري

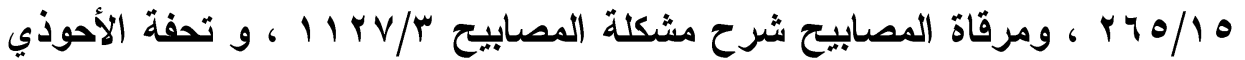

$$
\text { . } 110 / 7
$$

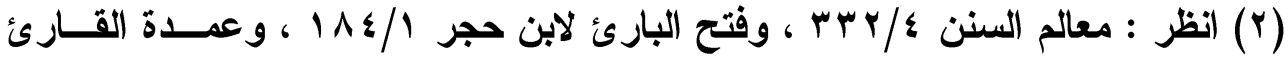

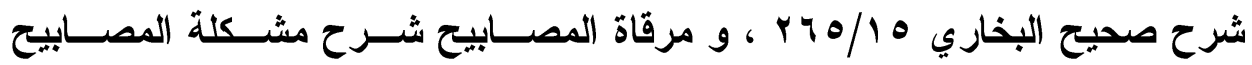

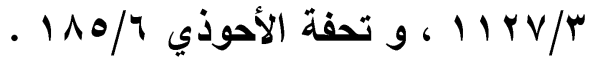

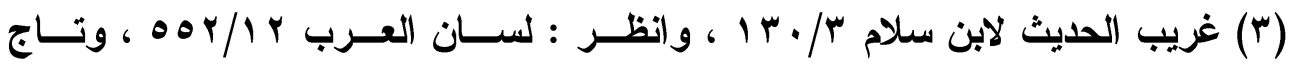

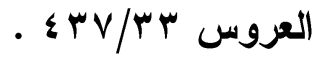




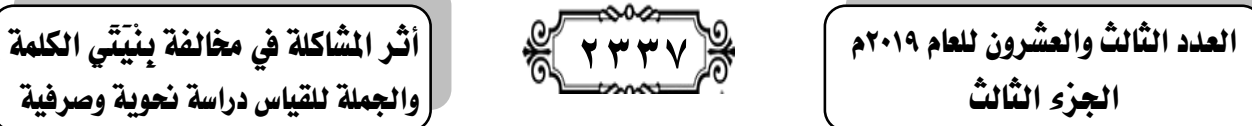

\section{العدول عن البمع السالم إلى التكسير للمشاكلة}

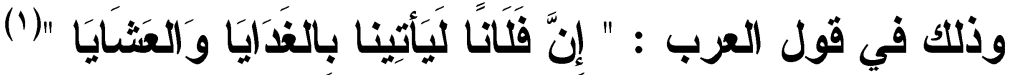

حيث جمت كلمة " غَدَاة " على " غَدَايَ " في هذا القــول ، وكـــان

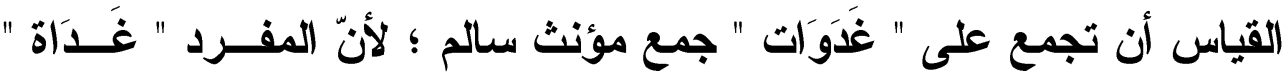

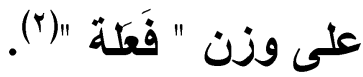

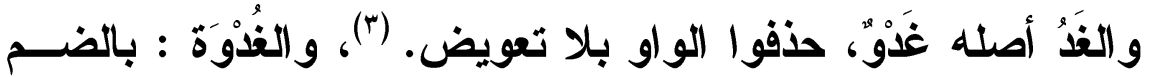

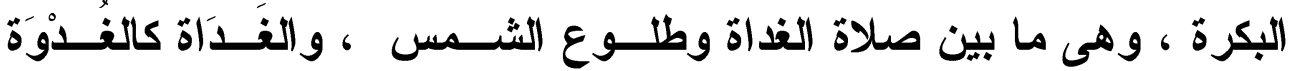

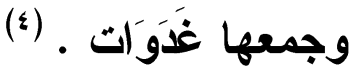

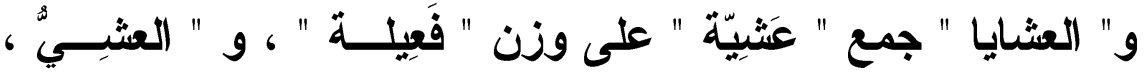

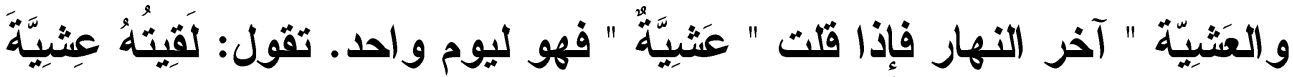

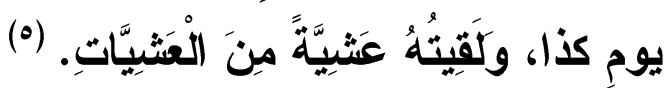
أما إذا جمعت " غَدَاة " جمع تكسير فالقياس أن تجمع على "غَدَاوَى" ،

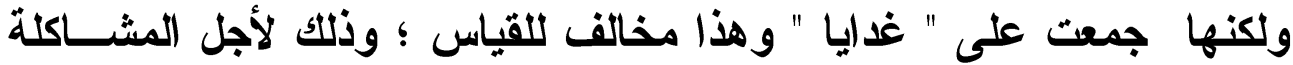

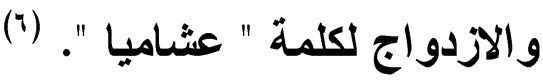

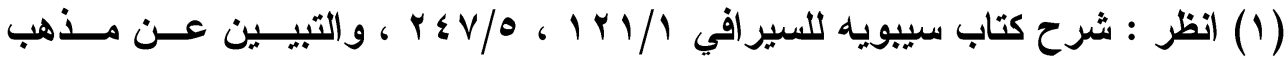

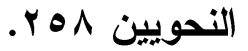

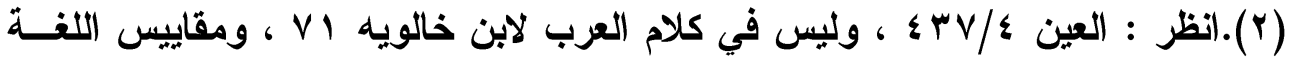

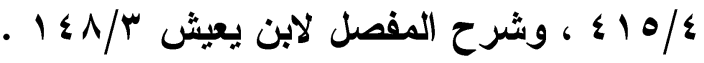

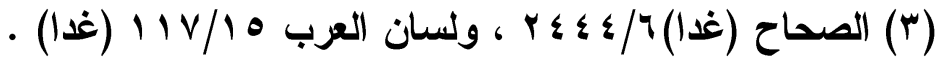

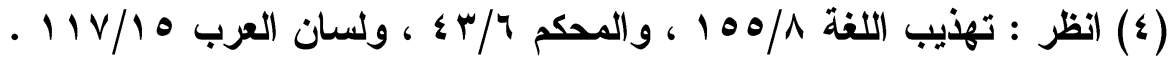

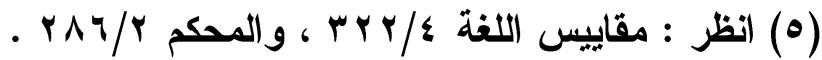

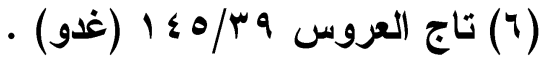




\section{الترقيم الدوله ISSN 2356-9050}

की
حولية كلية اللفة العربية بجرجا مجية مجلة علمية محكمة

ويبان ذلك فيما بأتي :

من جموع الكثرة وزن " فعائل " ، ويطرد هذا الوزن في كل رباعي مؤنث ثالثه مدة سواء كانت المدة ألفا ، أو ياء ، أو واوًا، ، وســواء كـــان

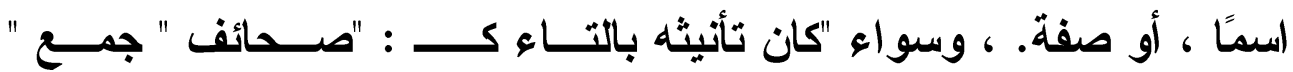
صحيفة " ، أو" كان ثأنيثه "بالمعنى كـ: " شمائل " جمع " شمال " . وهذا يشمل عشرة أوزان ( خمسة مختومة بالتاء وخمسة مجـردة

(1)

\section{وهى كالآتي :}

• ـ " فعالة " ـ مضموم الفاء أو مفتوحها أو مكسورها ـ نحو : " ذُؤُابه ،

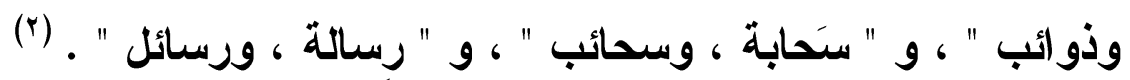
• " فَعولة " - بفتح الفاءع ـ ، نحو : " حمولة ، وحمائل .

• " فَعِلة " - بقتح فكسر - ، نحو : صحيفة ، وصحائف " ، ويشترط ألا تكون صفة بمعنى مفعولة ، كـ " جريحة " بمعنى مجروحة ، فلا يقـال :

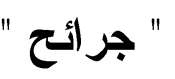

قال سيبويه : " وأمَّا ما كان عدد حروفه أربعة أحرف وفيــه هـــاء

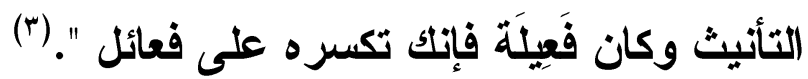

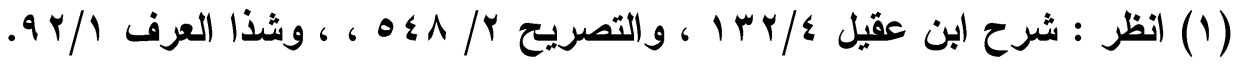

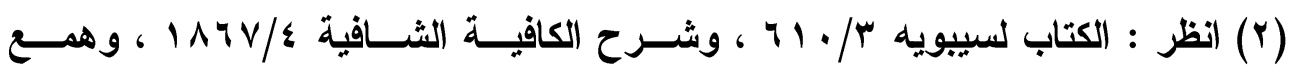

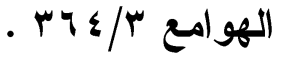

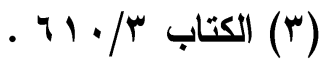




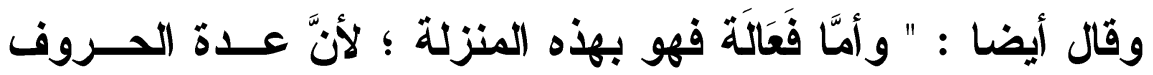

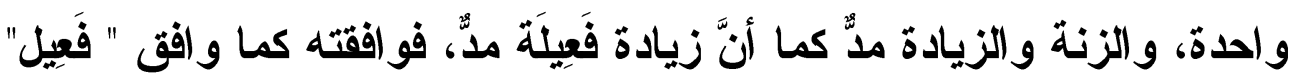

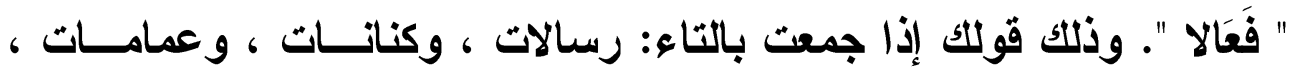

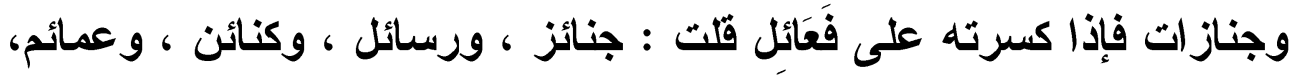
و الو احدة جنازة وكنانة وعمامة ورسالة. ومثلكه جناية وجنايا." (') وأما المجردة من التاء فيشترط فيها أن تكون لمؤنث معنوي ، وهى :

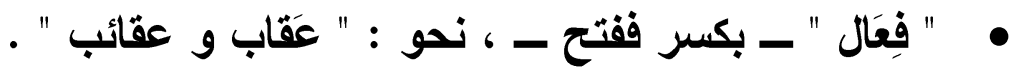

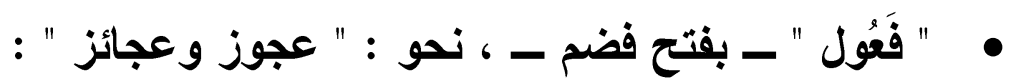

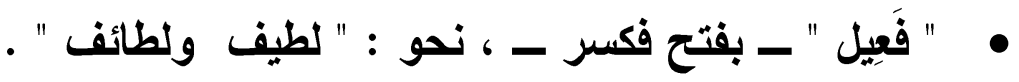

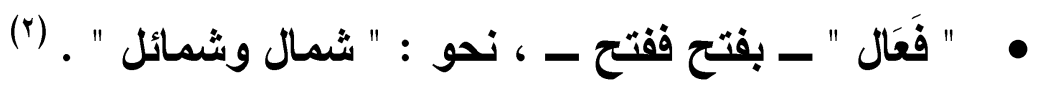

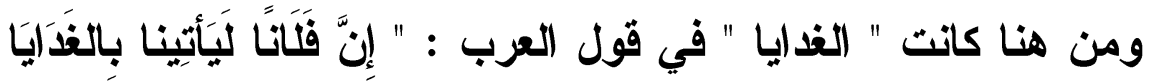

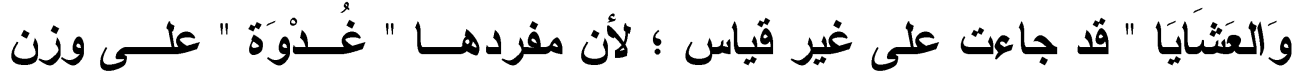

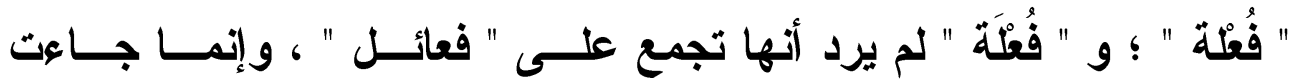

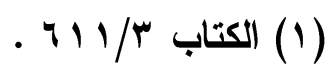

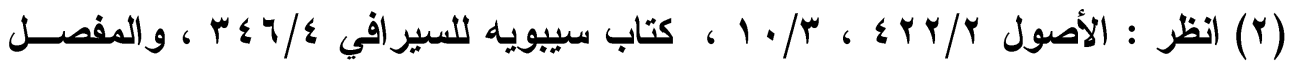

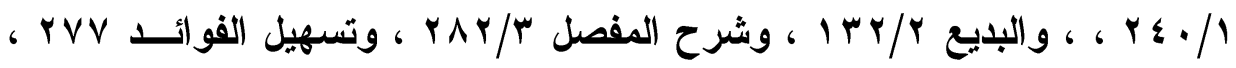

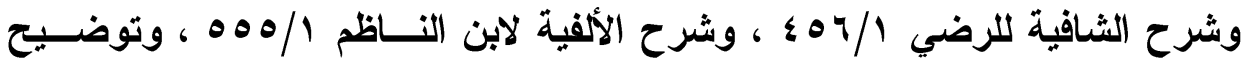

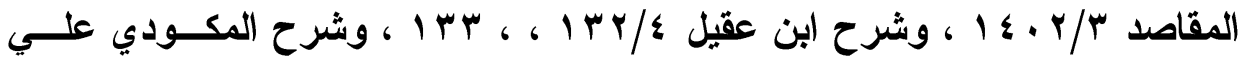

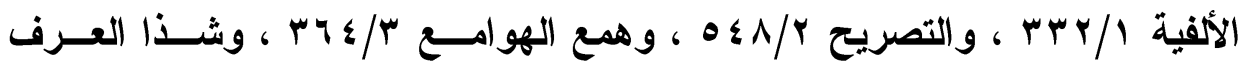

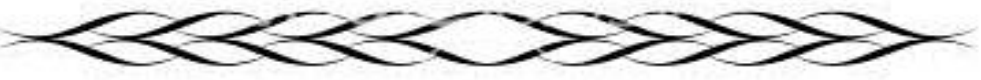




\section{الترقير الدول\$ \\ ISSN 2356-9050}

هنا علــى وزن " فعائسـل " ؛ لأجــل المشــاكلة والازدواج والإتبــاع للفــ

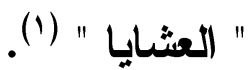

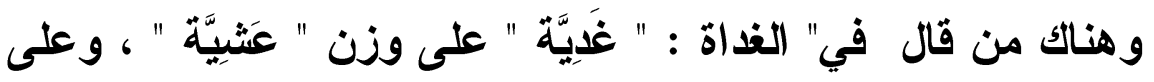

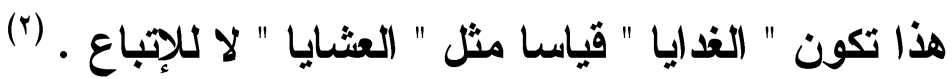

وهذا ما ذكره ابن الأعر ابي في نوادره : " ويقال : عَثَيَّة وعشايا ،

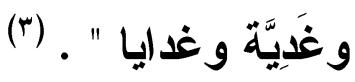

تمقيسب

تبين مما سبق أن مجيء " الغدايا "في هذا القول جمع " غَـدَاة " ،

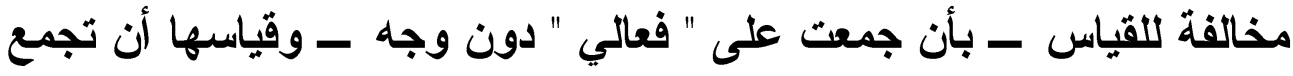
على "غدوات " إنما جاء لأجل المشاكلة .

وما قيل من أنها جمع " غَدَيَّة " وتكون قياسية إلا أنه يكون عـدول

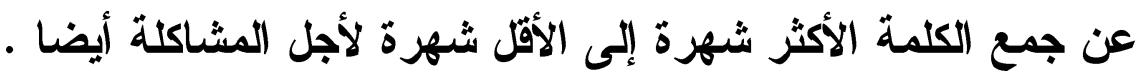

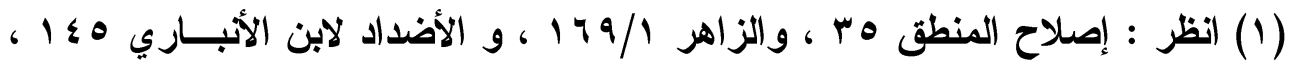

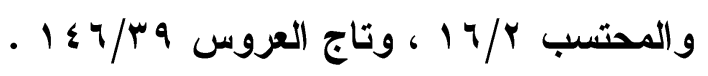

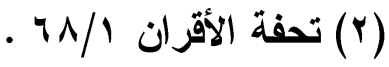

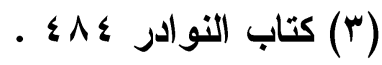




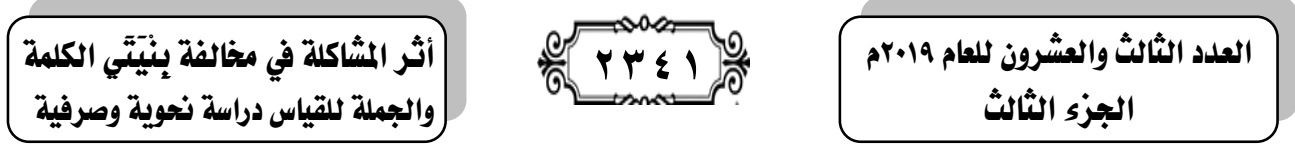

\section{العدول عن صيغة إلى آخرى في جمع التكسير للمشاكلة}

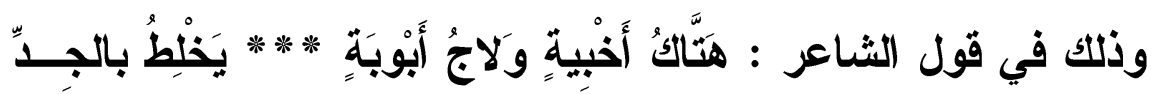

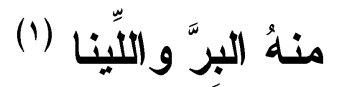

حيث جمعث كلمة " باب " على " أبوبة " في هذا البيث علــى غيـر

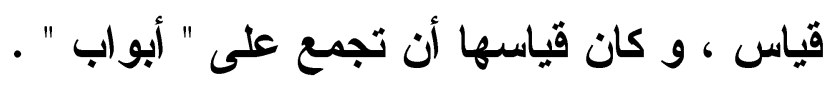

وييان ذلك فيما يأتي :

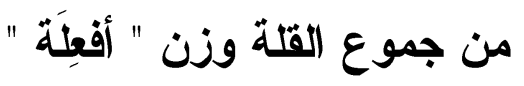

يطرد هذا الوزن في كل اسم مذكر رباعي ثالثه حرف مــــ زائــــ ،

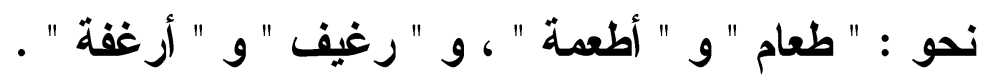

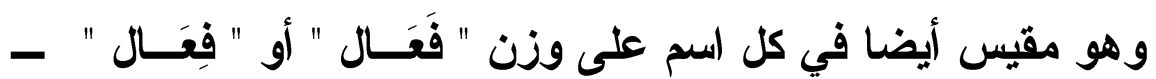

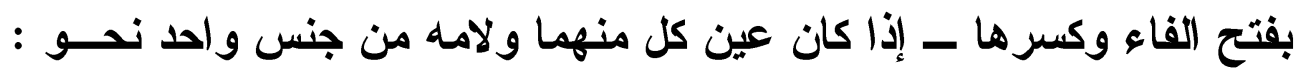

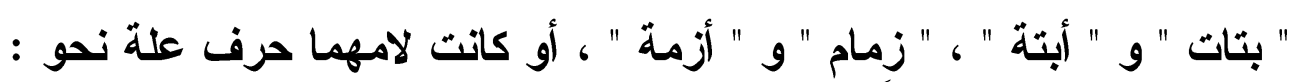

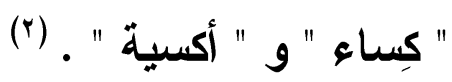

(1) من البسيط ، للقلاخ بن حبابة أو لابن مقبل

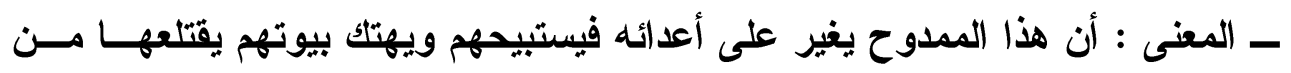

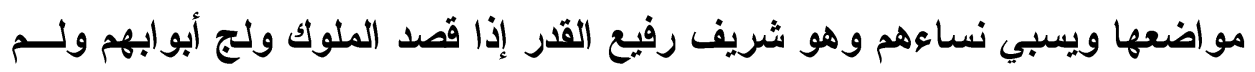

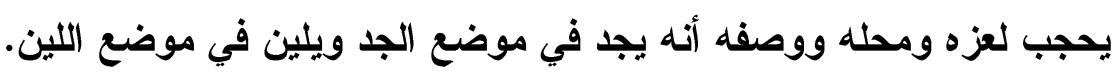

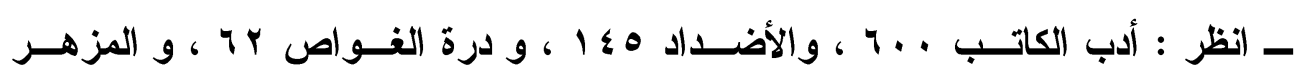
. r $r Y / /$

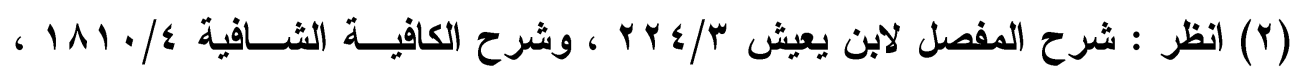

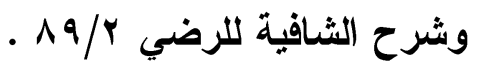




\section{الترقيم الدوله}

ISSN 2356-9050
Q

حولية كلية اللفة العربية بجرجا

مجلة علمية محكمة

ومن أوزان القلّة أيضا وزن " أفمّال "

$$
\text { • ويطرد في : }
$$

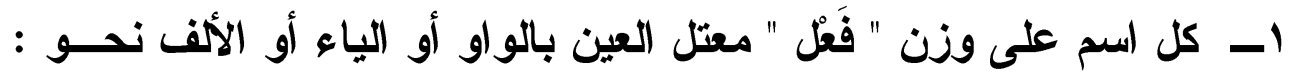

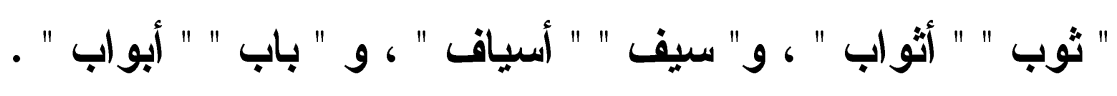

قال الرضي : " اعلم أَن الغالب أَن يجمع فَعْل المفتوح الفاء الساكن

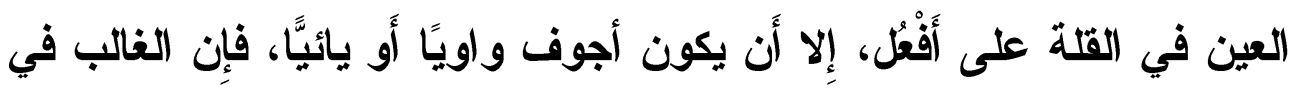

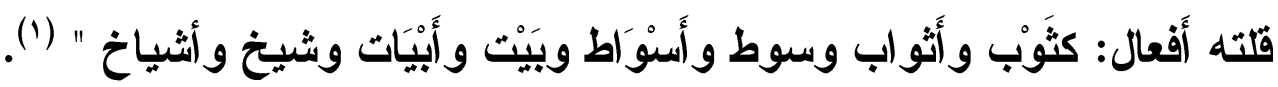

قال العكبري : "أمـا المعتل العين نحو : " ثوب " فيجمع فـــي القــــة

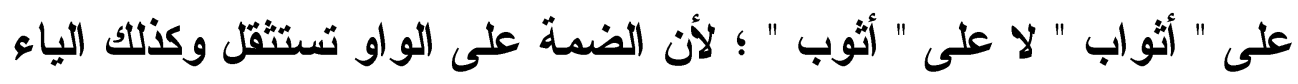

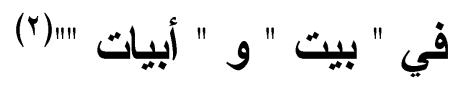

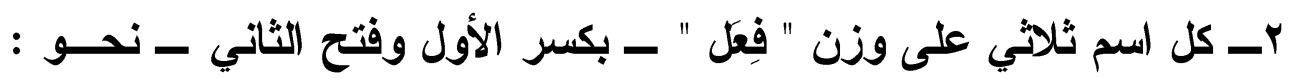

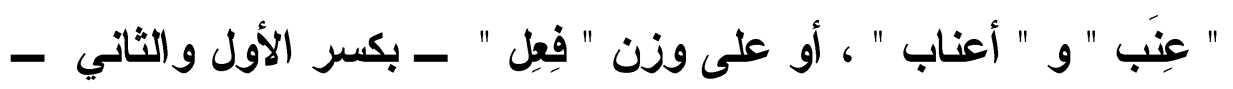

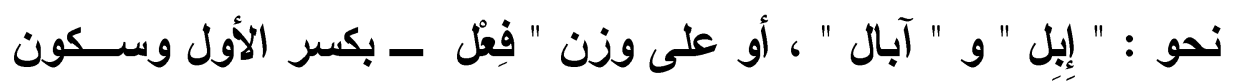

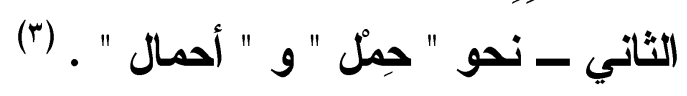

وعلى هذا فقد جاعت كلمة " (أبوبة " في البيت على غيـر قيــاس ؛

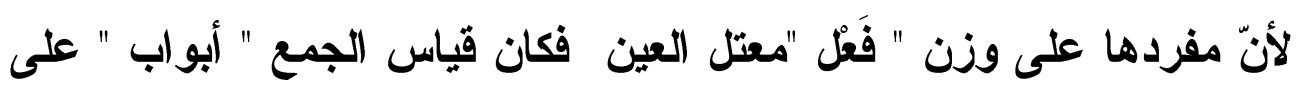

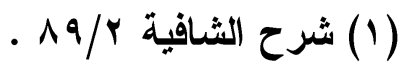

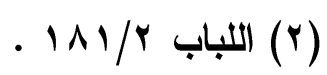

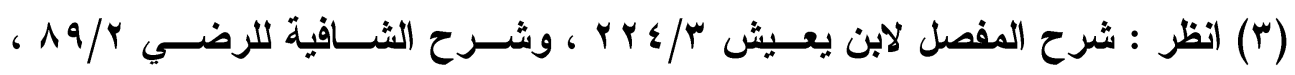

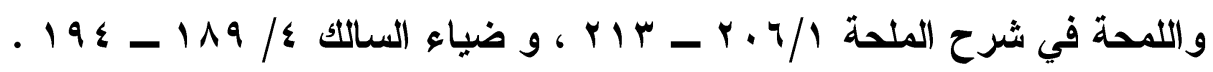


وزن " أفعال " ، و إنّما جاعت على وزن " أَفْعِة " ؛ لأجل المشاكلة والازدواج

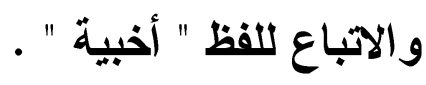
قال أبو بكر الأباري : " وأنثد الفراء :

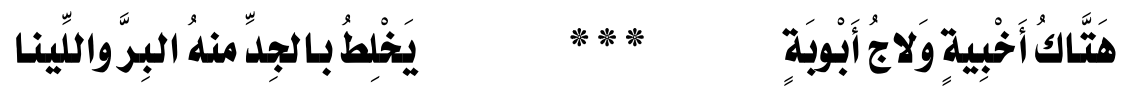

فجمع الباب " (أبوبة " ليزدوج مع " الأخبية." . (1)

يظهر مما سبق أن مجيء " أبوية " في هذا البيت وإن كان مخالفًا

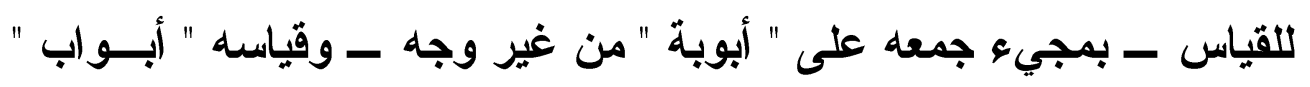
إنما جاء لأجل المشاكلة . أمئل

(1) شرح القصائد السبع الطوال الجاهليات آس 1 ـ .

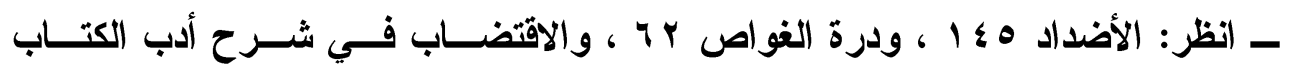

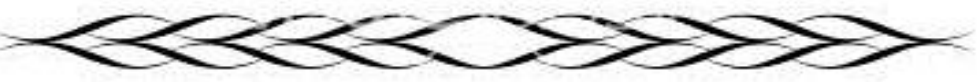




\section{الترقير الدولم \\ ISSN 2356-9050}

\section{قلب الواو همزة على غير قياس للمشاكلة}

وذلك في قوله ـ صلى الله عليه وسلم ـ : " ارْجْْـنَ مَسَأزُورَاتِ

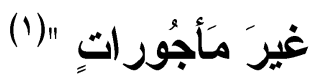

حيث استعملت كلمة " مَأزوُورَات " في الحديث الثريف وهي مسأخوذة

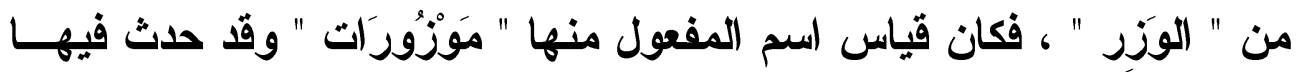

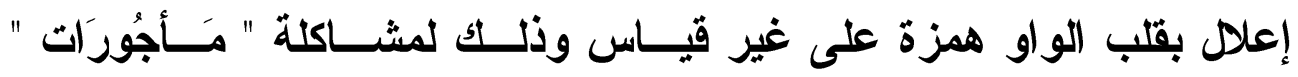

بعدها (†)

أما " مَأزُورَات " فهي من " أزر " بمعنى المظاهرة و المعاونة ، وهذا

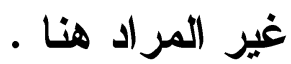

وييان ذلك فيما بأتي :

الإعلال هو : تغيير حرف العلة للتخفيف بقلبه أو إسكانه أو حذفه . (r)

وأما الابدال فهو : جعل حرف في مكان حرف آخر . (\&)

• هواضع قلب الواو هـهزة :

تقلب الواو همزة وجوبا في خمسة مواضع هى :

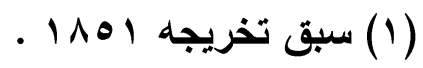

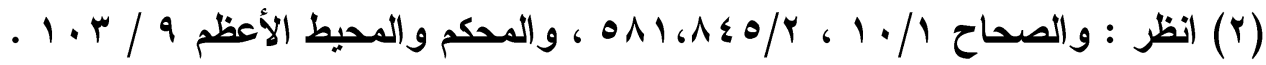

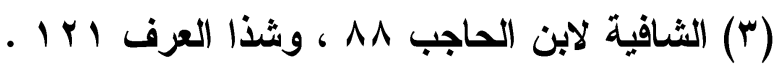

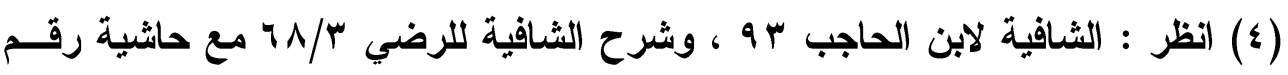

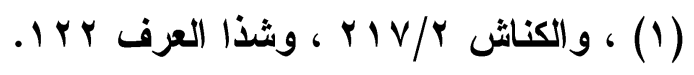




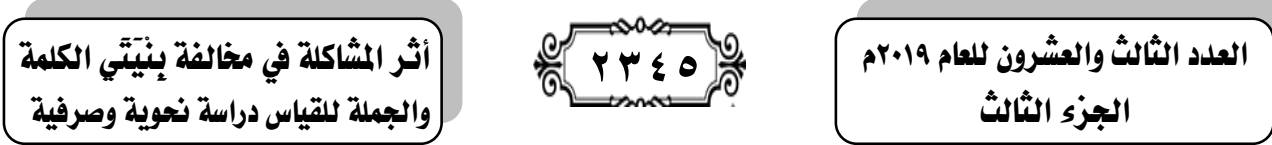

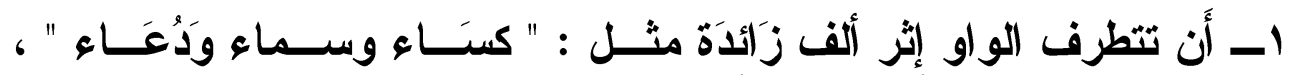

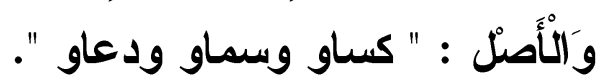

قال ابن عصفور : " ومن هذا القبيل ، عندي ، إبـــالأها مــن البـــاء

والواو ، إذا وقعتا طرفًا بعد ألف زائدة، نحو: كِساعِ ورداعِ. ".(')

r-ـــ أن تقع الواو عينا لاسم فَاعل فعل ثلاثي أعلت عين فعله نَحْو : " صَائم

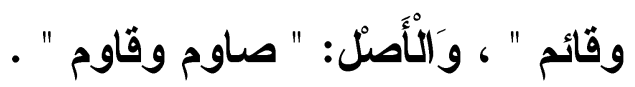

"اــ أن تقع الواو مدَّة ثُلاثية زائدة بعد ألف مفاعل. نحو: " عَجَائز " جمع " عَجْوز " ، والأصل " عجاوز ".

قال سيبويها : " وسألته عن واو عجوز وألف رسالةٍِ وياء صحيفةٍة

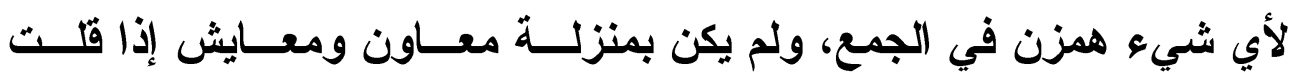
صحائف ورسائل وعجائز؟ فقال: لأكي إذا جمعث معاون ونحوها، فإنما أجمع ونع ما أصله الحركة، فهو بمنزلة ما حركت كجدول. وهذه الحروف لما لم يكـن أصلها التحريك وكاتت ميتةٍ لا تلدخها الحركة على حال، وقد وقعت بعد ألف،

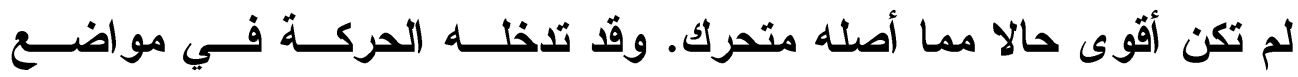

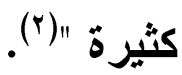

ع - أَنْ تقع الواو ثَانِي لينين اكتنفهما ألفف مفاعل مثل: " أَوَائلِ وســيائد " والأَصل: " أواول وسياود " في جمع " أول وسيد ".

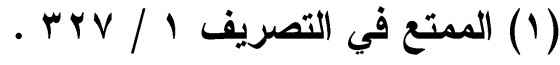

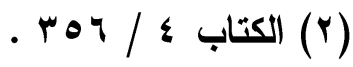

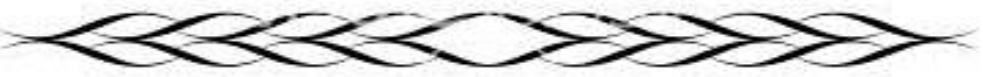




\section{الترقير الدولخ}

ISSN 2356-9050

قال سيبويه : " و إذا التقت الواوان على هذا المثال فلا تلتفتن إلـى

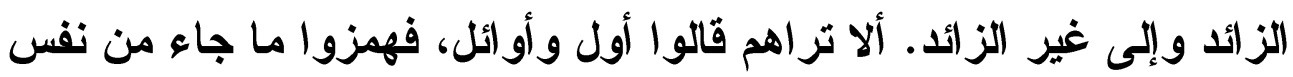
الحرف ..... وكذلك فواعل من قلت قوائل، لأهها لا تكون أمثل حسالا مسن

فواعل من عورت ومن أوائل " (1).

هـ أَن تتصدر في الكلمة واوان. فإِن الأولى منهما تقلب هزة بشرط أن لا

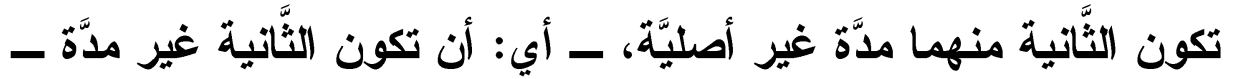

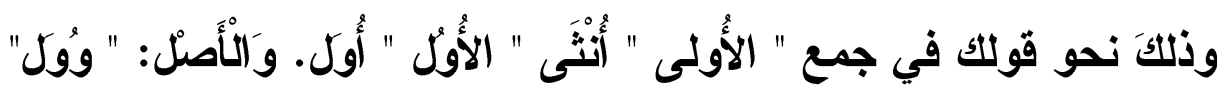

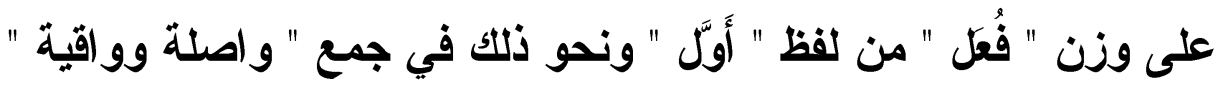

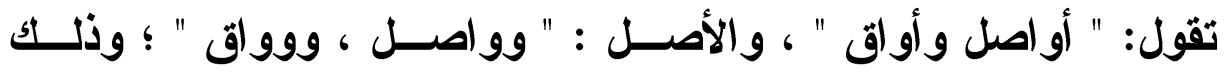

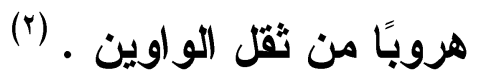
وتقلب الواو همزة جوازًا :

إذا كانت الواو فــاء مضــمومة مفـردة ، نحــو : " وجـوه " ،

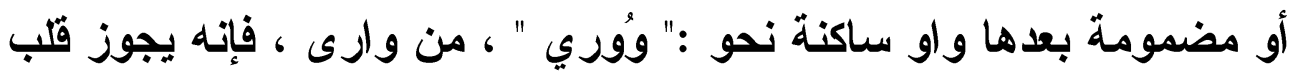

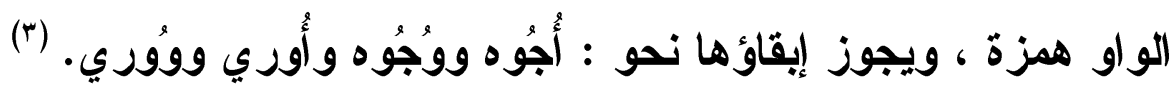
أو كانت الواو فاء مكسورة كما في : وسادة ، إسادة ، وفي وعاء: إعاء ؛ وذلك لثقل الضمة والكسرة في الواو ـ

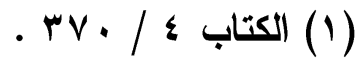

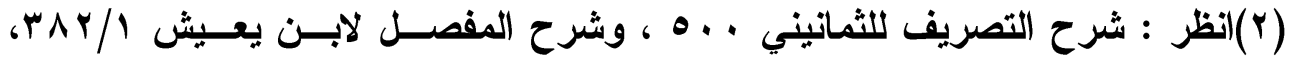

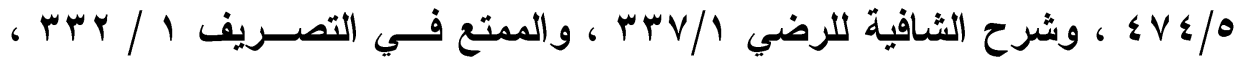

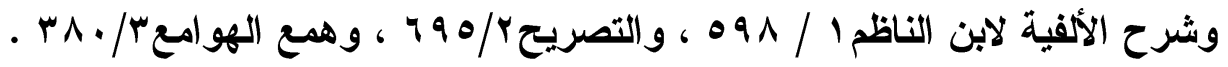

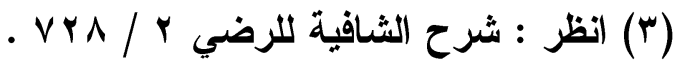


وأما المفتوحة فإبلالها همزة قليل ، وموقوف على الســماع كمــا

$$
\text { قالوا: أحد في "وحد ". (1) }
$$

قال المازني : "واعلم أن الواو إذا كانت أولا، وكانت مكسورة فمن العرب من يبدل مكانها الهمزة ويكون ذللك مطــردا فيهـــا، فيقولــون فـيـي " وسادة" : " إبسادة "، وفي " وعاء " : " إعاء " ، وفي " وفادة " : " إفادة "؛ .............. غير أول، لا يقولون في طويل وعويل ونحو ذلك إلا بالواو". (†) وقد جاءت كلمة " مأزور ات " في الحديث على غيـر فيــاس ؛ لأنّ قلب الواو فيها لم يرد في أي موضع من مواضع قلب الواو همزة ، وقاـب الواو همزة فيها ؛ إنما كان لأجل المشاكلة للفظ " مأجورات " . (r)

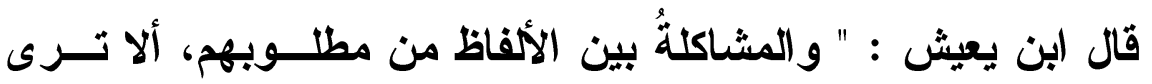
أنهم قَالوا: "أَخَذَهُ ما قدُم وما حدُث" (؛)، فضمّوا فيهما. ولو انفرد، لم يقولوا

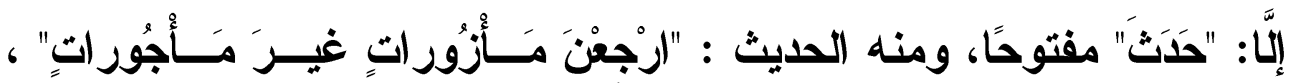

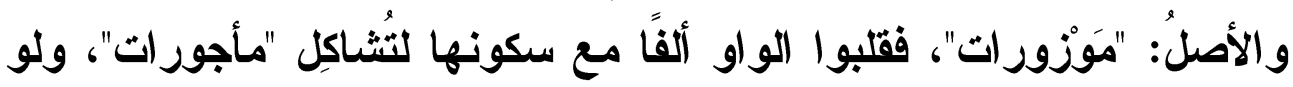

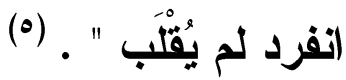

$$
\begin{aligned}
& \text { (1) انظر : تمهيد القواعد •1 / 1 10.0 ، } 17 \text {.0. }
\end{aligned}
$$

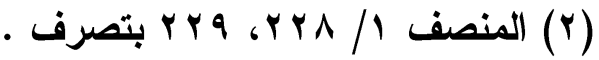

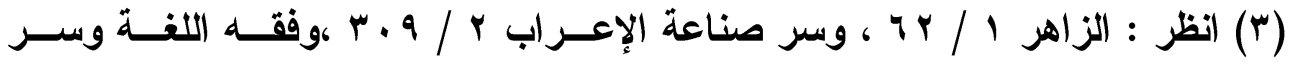

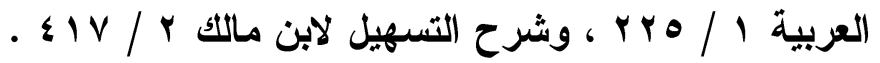

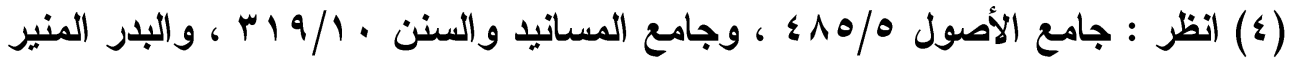

$$
.1 \mathrm{VT} / \varepsilon
$$

(0) شرح المفصل لابن يعيش ه / ع ع. r. 


\section{الترقير الدولم ISSN 2356-9050}

يتضِح مما سبق أن مجيء " مَسـأزوُورات " و أصــــها " مـــوزورات "

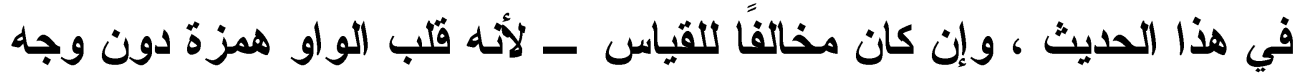

- - إنما جاء لأجل المشاكلة . 


\section{قلب الواو ياء على غير قياس للمشاكلة}

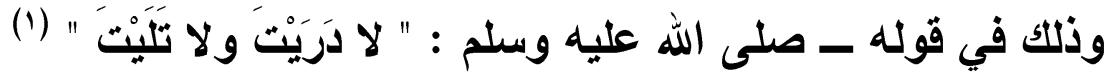

حيث استعملت كلمة " تليت " بقلب الواو ياء على غير قياس فــي

الحديث الثريف ، وكان قياسها أن يقال " تلوت " ؛ لأنها من " تــلا "و ألفــهـ

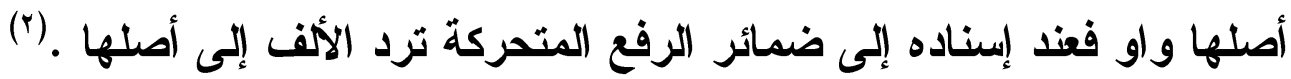
وييان ذلك فيما بأتي :

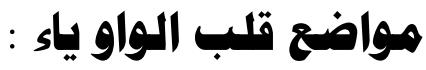

تقلب الو او ياء وجوبا في عشرة مواضع مجملها :

ا- أن تقع متطرفة بعد كسر سواء أكانت متطرفة تطرفًا حقيقية أو حكَّـا

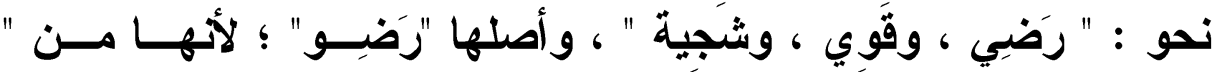

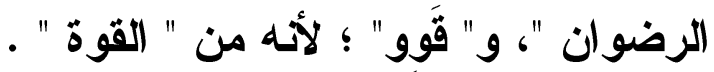

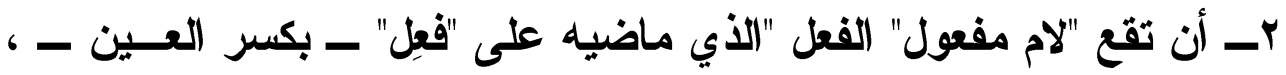

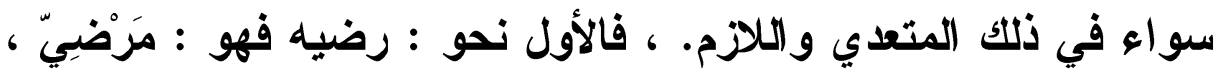

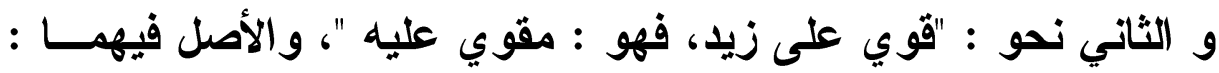

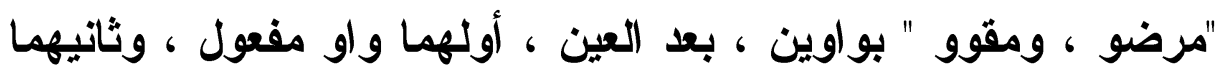

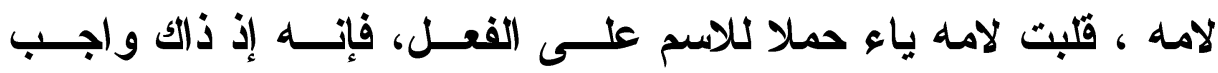

(1) أخرجه البخاري في صحيحه كتاب الجنائز - باب الميت يســع خفـق النعـال ـ

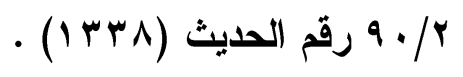

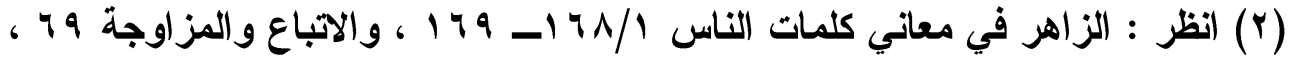

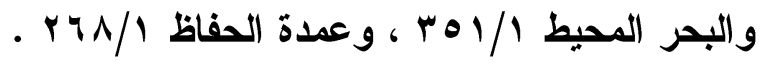




\section{الترقير الدولخ}

ISSN 2356-9050
Trom

حولية كلية اللفة العربية بجرجا مجلة علمية محكمة

الإعلال، إذا الحرف الأي قبل الآخر مكسور، فصارا "مرضويا، ومقوويا" فاجتمع فيهما الواو والياء، وسبقت إحداهما بالسكون، فقلبث الواو ياء، وأدغمت الياء في الياء، وأبدلت الضمة كسرة لتسلم الياء مسن القلـب واوًا .

"اــ أن تقع عينا لجمع صحيح اللام ، وقبلها كسرة ، وهي في المفرد معلة أو شبيهة بالمعلة ـ وهي الساكنة بعد فتح ـ نحو : " دار وديار " ، و" ثَوَبْ وثِباب " والأصل : "دوار وثواب ". عـــأن تقع طرفًا رابعة فصاعدًا بعد فتحة ، نحو : أعطيث أصله أعطــوت لأكه من عطا يعطو - إذا تناول - فقلبت الواو في الماضي ياء حمـلا على المضارع نحو يعطى كما حمل اسم المفعول نحو معطيان على اسم الفاعل نحو معطيان وكذلك يرضيان أصله يرضوان هـ أن تقع عينًا لمصدر أعلت في فعله ، "ويكون قبلها كسـرة ، وبعـدها ألف"، نحو : " صيام ، وقيام " ، والأصل فيهن : "صِوَام ، وقِوَام " . צ- أن تجتمع الواو والياء في كلمة واحدة ، والسابق منهما ساكن متأصـلـ

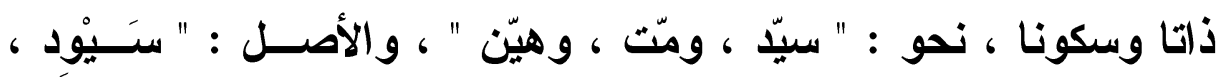
ومَيْوِت ، وهَيْون " .

V- أن تقع الواو " لام فُعول ـ بضم الفاء ـ جمعًا، نحو: " عصا وعصي " ، و" ققا وقفي "، و" دلو ودلي" ، والأصل : "عصوو ، وققوو ، ودلوو "، فاستثقلوا اجتماع واوين في الجمع، فقلبوا الواو الأخيرة ياء . 


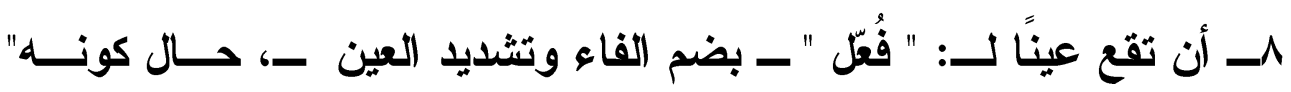

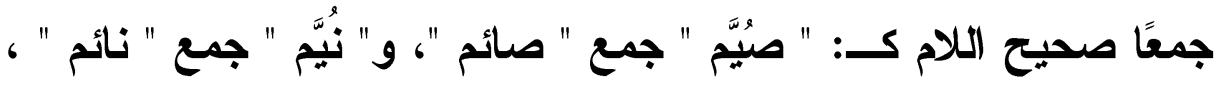

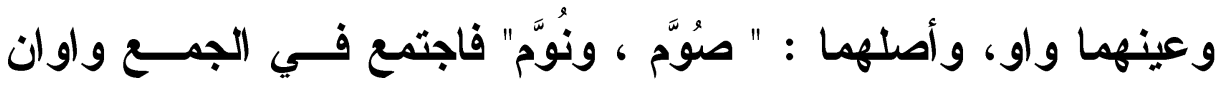
وضمة ، فكأنها اجتمع ثلاث واوات مع ثقل الجمع، فعدل إلى التخفيــف بقلب الواوين ياعين ؛ لأن الياعين أخف من الواوين . 9- أن تقع لاما د " فُعْلى " بالضم حال كونها صفة ، نحو قوله ــ تعالى ــ :

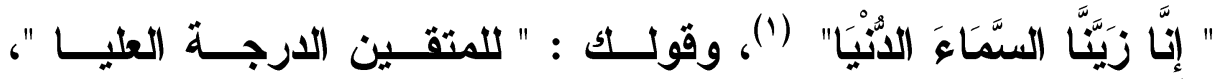
والأصل: " الانوى ، والعلوى " ؛ لأكهما من "الانو ، والعلو " قلبت الواو فيهما ياء لاستثقال الواو والضمة وعلامة التأنيث في الصفة ، فخفةــ لامها بقلبها ياء

• إ- أن ثقع ساكنة مفردة بعد كسر ، نحو : " ميزان " ، أصله : " موزان"؛

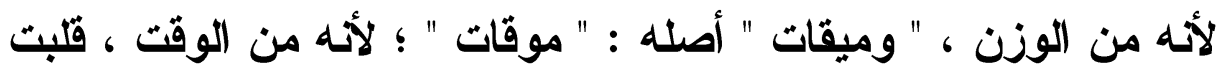

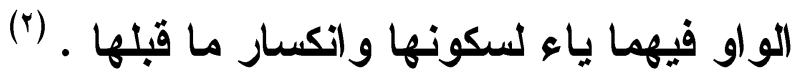

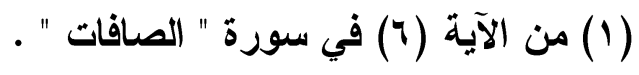

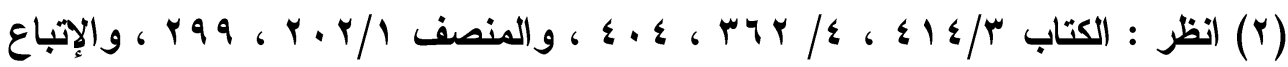

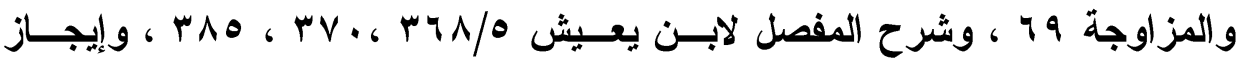

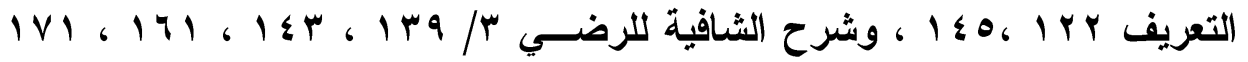

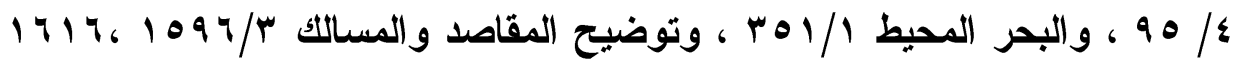

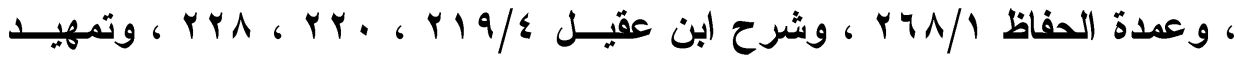

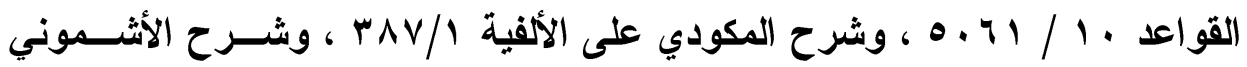

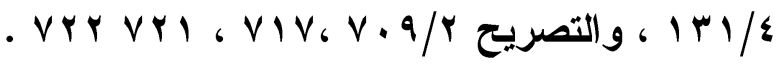


الترقير الدول\$ ISSN 2356-9050

تحتمل كلمة " تليت " ثلاثة أوجه :

ا- أن تكون " جاعت على غير قياس ؛ لأكها لا تندرج تحت أي موضع من مواضع قلب الواو ياء ، وإنما جاءت بالياء لأجل المشاكلة والمؤاخــاة

$$
\text { والإبباع للفظ " دريث " . }
$$

قال ابن حجر في فتح الباري : " قوله : تَا دَريت وكَا تليــت قيــلـ :

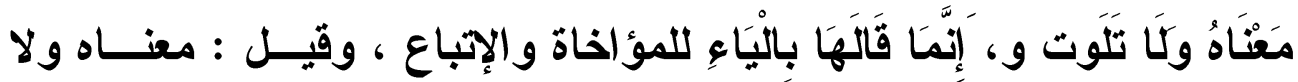

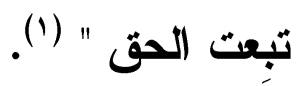

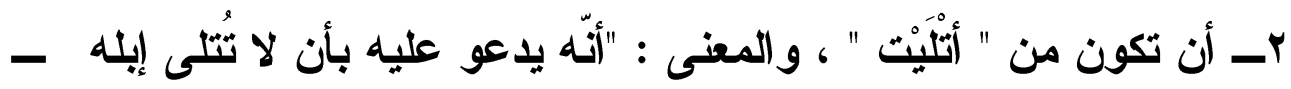

$$
\text { أي لا يكون لها أولاد - - أنون }
$$

حُكي عن يونس بن حبيب " لا دَرَيْتَ ولا أَتْلْيَتْ " ، والمعنى : أنَّـهـ

$$
\text { يلاعو عليه بأن لا تُتلى إبله ــ أي لا يكون لها أولاد - . }
$$

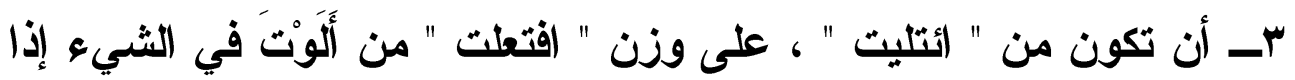

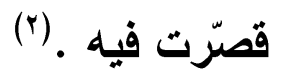

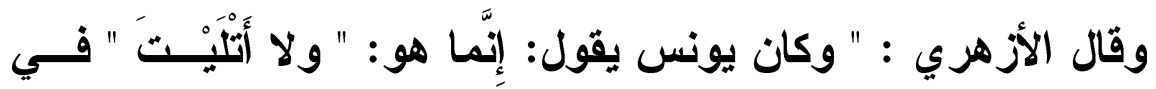

كلام العرب: " معناه ألا يتلي إبلَه ، أي لا يكون لها أولاد تثتوهـــا " ، وقــال

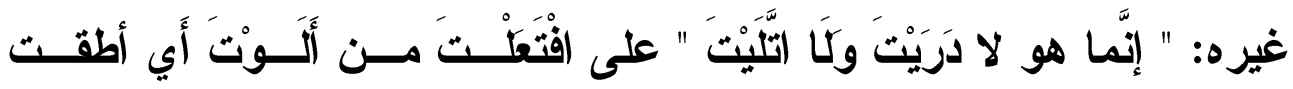

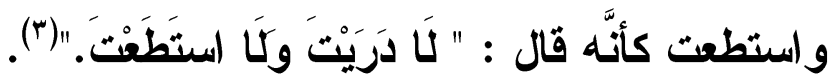

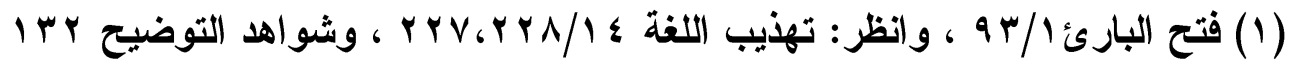

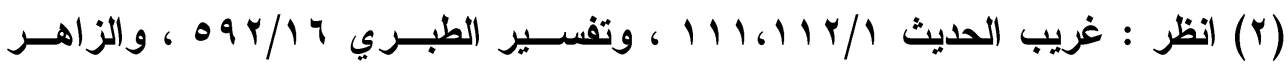

$$
\begin{aligned}
& 171 / 1
\end{aligned}
$$

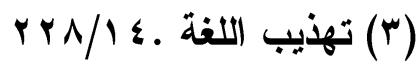


ونسب هذا القول للفراء والأصمعي (')، وصوّب هذا القــول ابــن

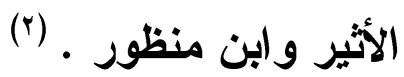

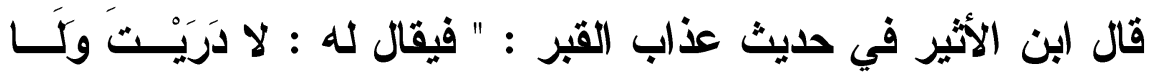

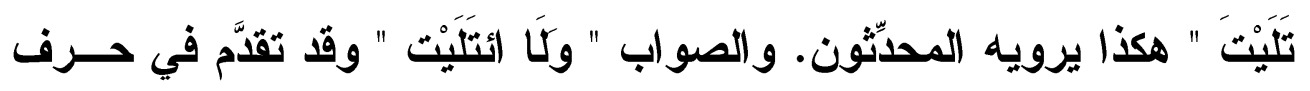
الهمزة .

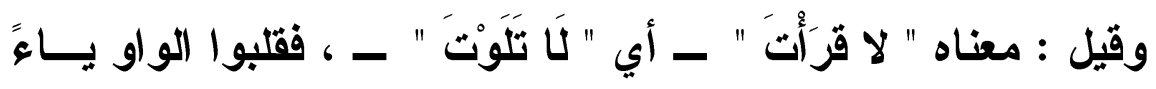

ليزدوج الكلام مع دريَتْ.

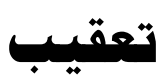

يتضح مما سبق أن مجيء " تليت " في هذا الحديث وإن كان مخالفًا

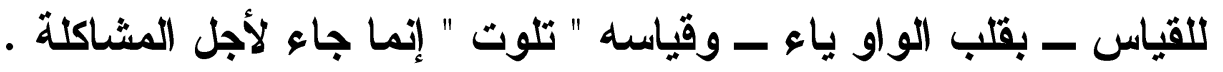
وما قيل في تخريجه من أقوال أخرى قياسية فيكون جاء لمحسـن

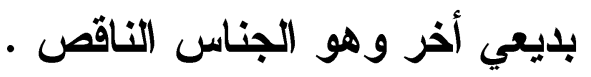

(1) انظر : إصلاح المنطق رrr ، و الفاخر ^r.

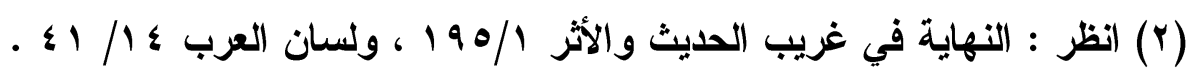




\section{الترقيم الدولم \\ ISSN 2356-9050}

قلب الياء واو على غير قياس للمشاكلة

وذلك في قول العرب للرجل إذا قدم من سفر •

حيث استعملت كلمة " طَوَبَّة " في هذا القول على غيـر قيـاس ،

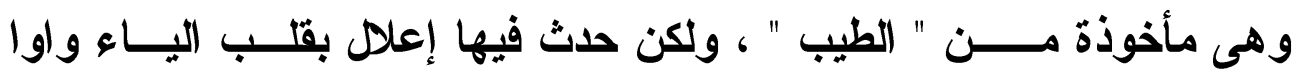

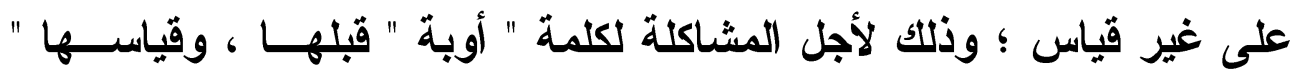

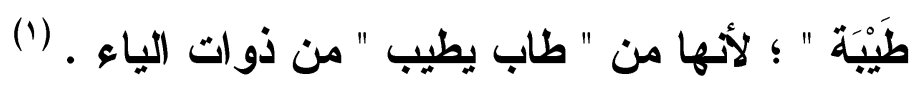

وبيان ذلك فيما بأتي :

$$
\text { تقلب الياء واوا في أربعة مواضع : }
$$

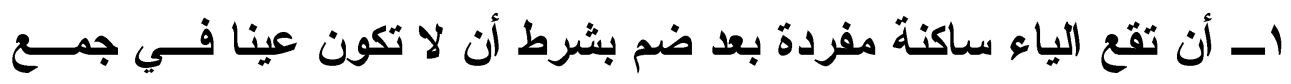

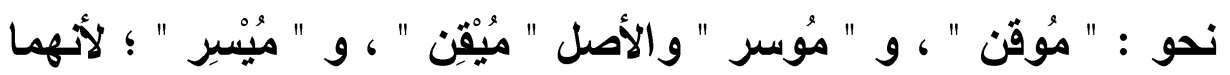
من أيقن ، وأيسر فقلبت الياء واوا لالضمام ما قبلها.

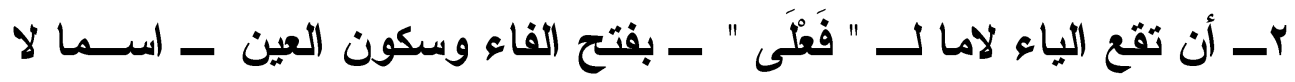

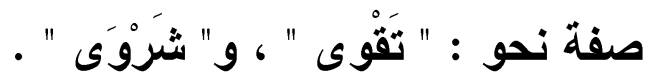

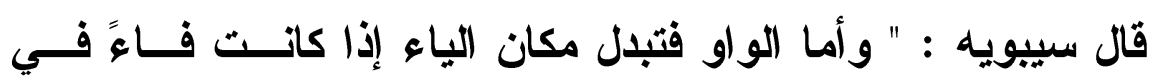

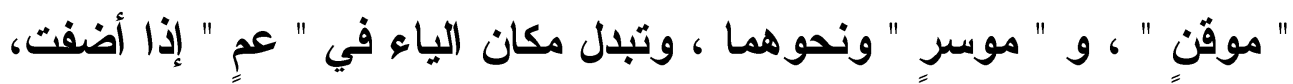

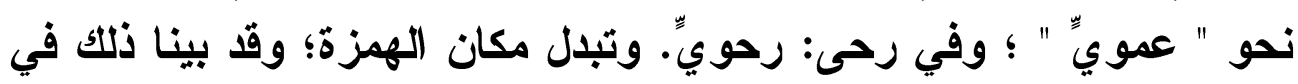
باب الهمز .

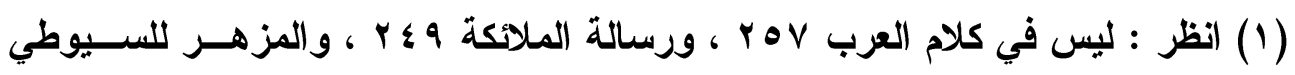
$r v \cdot /$

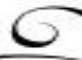




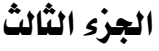

وتبلل مكان الياء إذا كانت لامًا في شروى وتقوى ونحوهــا. وإذا

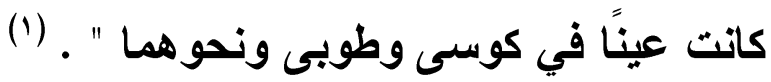

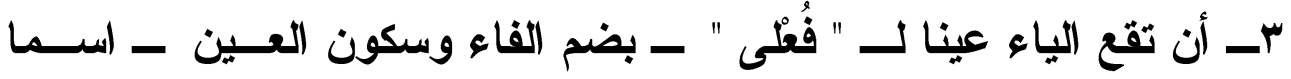

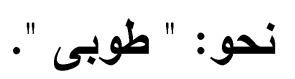

عــ أن تقع الياء المتحركة بعد ضم فإن كانت لام فَعُل ــ بضم العين - نحو:

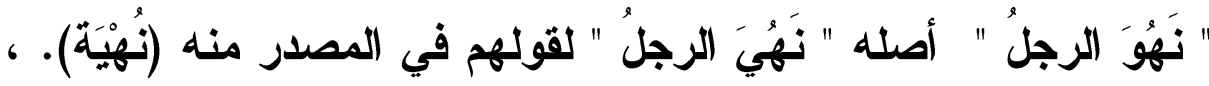

ونحو : " قَضُوُ الرجل " بمعنى : ما أقضاه. (r).

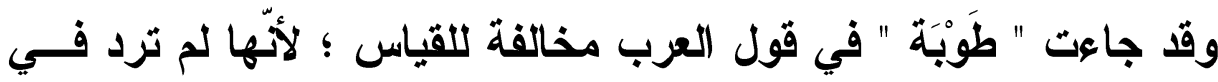

أيّ موضع من مواضع قلب الياء واو ، و إنما جاءت هكذا لمشاكلة " أَوْبَة" .

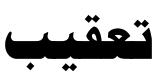

يتضح مما سبق أن مجيء " طَوَبَة " في هذا القول مخالفًا للقيــاس

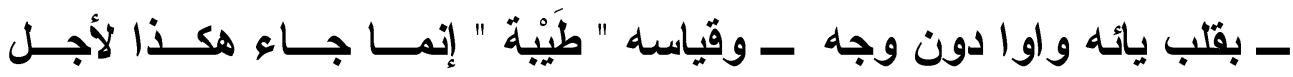

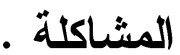

قال ابن خالويه : " ويقال للراجع من السفر: أوبة وطوبة وهذا غلط ، إنمــا

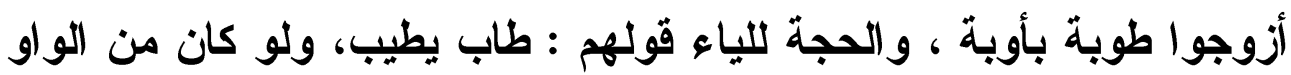

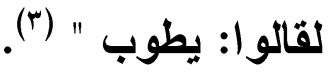

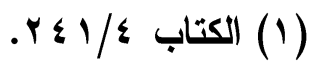

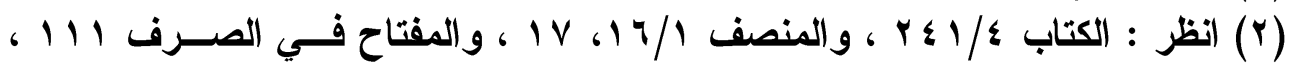

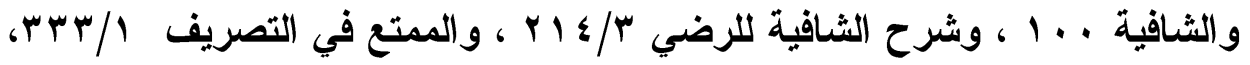

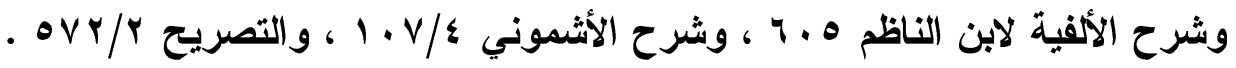

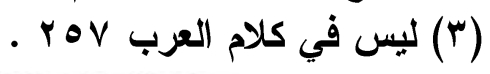




\section{الترقير الدولم \\ ISSN 2356-9050}

\section{الخاتهمة}

الحمد الله الأي بنعته تتم الصالحات ، والصلاة والسلام على أثرف الخلق سيدنا محمد ـ صلى الله عليه وسلم ـ وعلى آله وصحبه ومن تبعهم

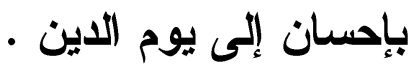

\section{وبعد}

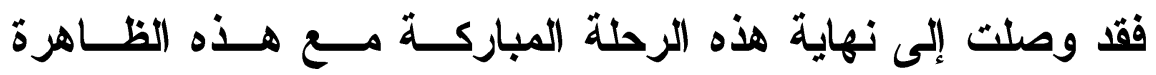

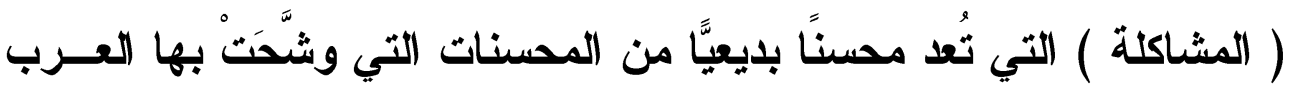
كلامها ، وزينت بها ألفاظها ، وأسباليبها ، وناقشها البلاغيون والنحويــون

$$
\text { تحت أسماء متعددة كلها ترجع إلى مسمى واحد . }
$$

أـ أنّ ظاهرة المشاكلة دخلت الكلام العربي بكل مستوياته قر آنًا ، وحــديثًا

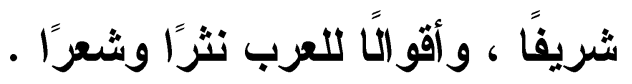

r - أنّ العرب كي تصل إلى هذا المحسن اللفظي غيرت في بنيتي الكلمــة

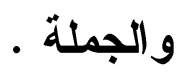

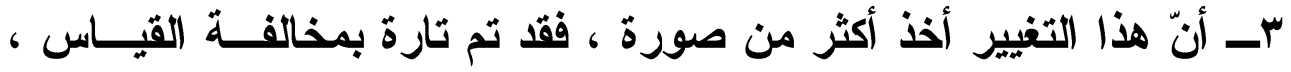

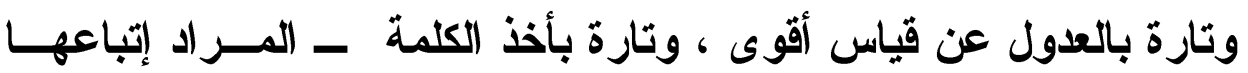

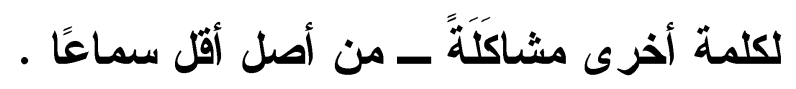

وأخيرا أرجو أن أكون بهذه الاراسة قد حاولت كثفت النقاب عـن

\section{ظاهرة المشاكلة وأثرها عند النحويين .}

واسئل الله - تعالى ـ أن يجعل عملي هذا خالصًا لوجهه الكــريم ،

$$
\text { وأن يجعله في ميزان حسنات و الايّ وحسناتي • }
$$

$$
\text { وآخر دعوانا أن الحمد للَّه رب العالمين }
$$




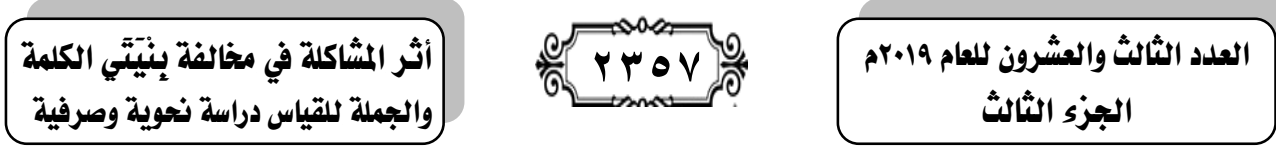

\section{ثبت بأهم المسادر والمراجع}

\section{أولا : القرآن الكريم · \\ ثانيا : الاصادر والمراجع القاهر / مصر}

• الإنباع لأبي علي القالي ، تحقيق : كمال مصطقى ، مكتبة الخــاتجي -

• الإتباع والمزاوجة لأحمد بن فارس ، تحقيق : كمال مصطقى ، مكتبـة الخانجي - القاهرة / مصر ماند

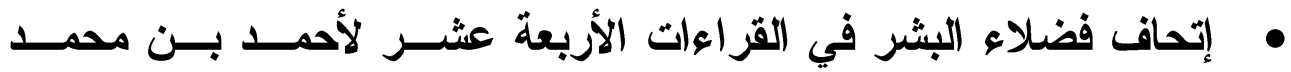
الدمياطيّ" ، تحقيق : أنس مهزة ، دار الكتب العلمية - لبنان ، الطبعـة

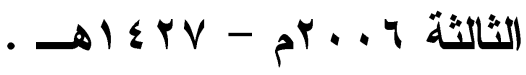

الإتقان في علوم القرآن لجلال الدين السيوطي ، تحقيق : محمـــ أبـو

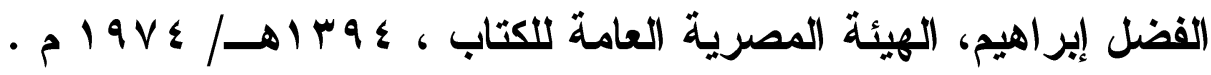
• أدب الكاتب (أو) أدب الكتّاب لابن قتيبة الــدينوري ، تحقيـق : محمـــ

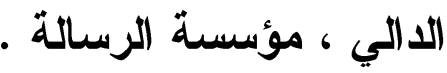
إسفار الفصيح لأبي سهل الهروي ، تحقيق : أحمد بن سعيد بن محمـــ قشاش الناشر : عمادة البحث العلمي بالجامعــة الإســلامية ، المدينــة

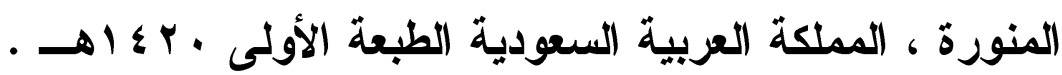
• إصلاح المنطق لابن السكيث ، تحقيق : محمـــ مرعـبـ ، دار إحيــاء

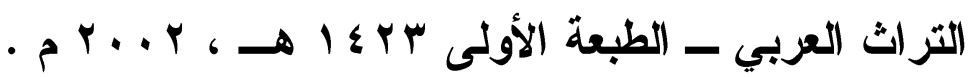
• الأصول في النحو لابن السراج ، تحقيق : عبد الحسين الفتلي ، الناشر: مؤسسة الرسالة لبنان - بيروت .

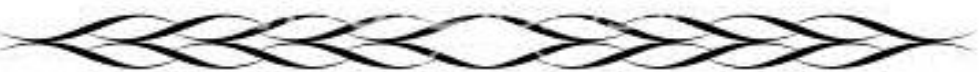




\section{الترقير الدولخ}

ISSN 2356-9050

• الأضداد لأبي بكر الأباري ، تحقيق : محمد أبو الفضل إبراهيم المكتبة

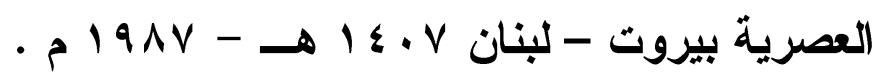

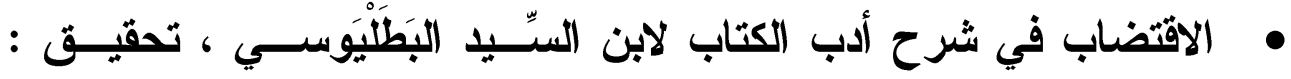
الأستاذ مصطفى السقا - الاكتور حامد عبد المجيد ، مطبعة دار الكتـب

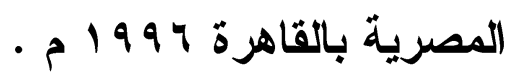

• أمالي ابن الحاجب لابن الحاجب الكردي المالكي ، دراسة وتحقيق : د. فخر صالح سليمان قدارة ، الناشر : دار عمار - الأردن، دار الجيـلـ -

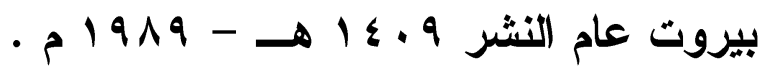

• أوضـح المسالك إلى ألفية ابن مالكك لابن هثام الأصـــاري ، تحقيـق : يوسف الشيخ محمد البقاعي ، دار الفكر للطباعة والنشر والتوزيع •

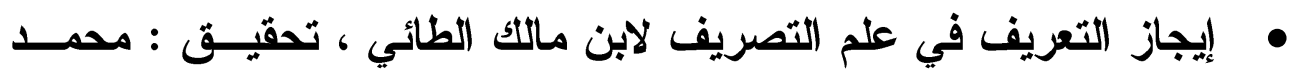
المهدي عبد الحي عمار سالم، عمادة البحث العلمي بالجامعة الإسلامية،

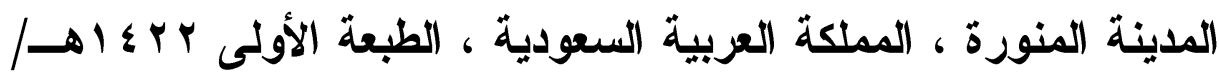
$\cdot r^{r} \cdot r$

• الإيضاح في علوم البلاغة لجلال الاين القزويني الثــافعي ، تحقيـق : محمد عبد المنعم خفاجي الناشر : دار الجيل - بيروت الطبعة الثالثة . • البحر المحيط لأبي حيان ، تحقيق : صدقي محمد جميل ، دار الفكـر - -

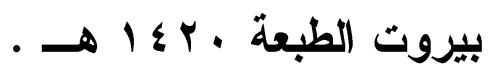
• البدر المنير في تخريج الأحاديث والأثنار الواقعة فـي الثــرح الكبيـر لسراج الاين أبو حفص عمر بن علي بن أحمد الثــافعي المصــري ، تحقيق : مصطفى أبو الغيط وعبد الله بن سليمان وياسر بن كمال ، دار 


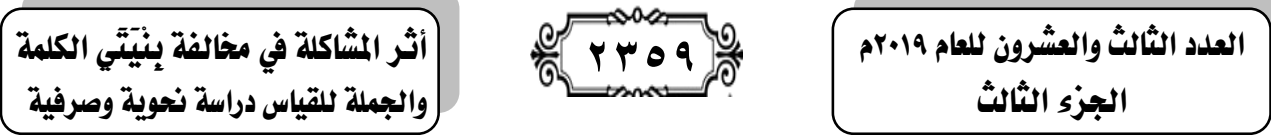

الهجرة للنشر والتوزيــع - الريــاض-الســعودية، الطبحـة الاولــى $\cdot \hat{r}^{r} \cdot \varepsilon-\Delta \leq r 0$

البديع في علم العربية لأبي السعادات المبارك ، تحقيــق ودر اســـة : د. فتحي أحمد علي الاين ، جامعة أم القرى، مكــة المكرمـــة - المملكــة

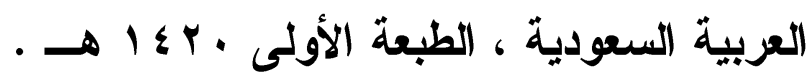

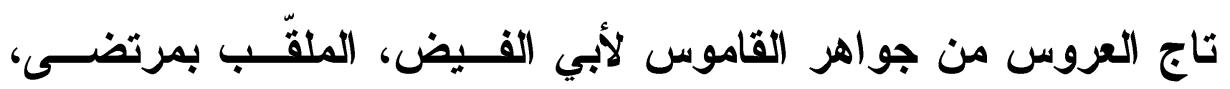
الزَّبيدي ، تحقيق : مجموعة من المحققين ، الناشر : دار الههاية . • التبيين عن مذاهب النحويين البصريين والكوفيين لأبي البقاء العكبري ، تحقيق : د. عبد الرحمن العثيمين ، الناشــر : دار الغــرب الإســلامي

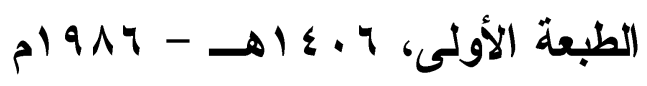

التحريز والتتوير لمحمد الطاهر بن محمد بن محمد الطاهر بن عاثور ،

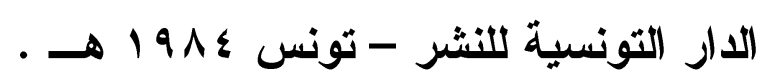

تحفة الأحوذي بشرح جامع الترمذي لأبي العلا محمد عبد الرحمن بـن عبد الرحيم المباركفورى ، دار الكتب العلمية - بيروت .

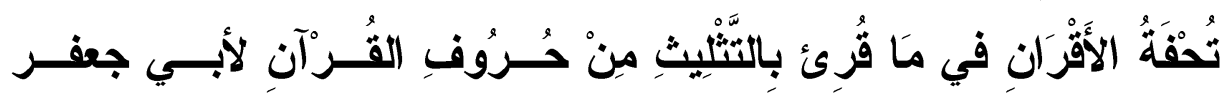
الأندلسي ، كنوز أثبيليا - المملكة العربية السعودية ، الطبعة الثانيـة

$$
\text { . } r \cdot v-\rightarrow 1 \leqslant \Lambda r
$$

• التذييل والتكميل في شرح كتاب التسهيل لأبي حيان الأدلسي ، تحقيق : د. حسن هنداوي الناشر : دار القلم - دمشث (من ا إلى •)، وبـاقي الأجزاء: دار كنوز إثبيليا الطبعة الأولى • 


\section{الترقيم الدولي}

ISSN 2356-9050
Trat.

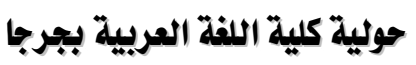
مجلة علمية محكمة

• تسهيل الفوائد وتكميل المقاصد لابن مالك الطائي الجيــاني ، تحقيــق : محمد كامل بركات الناشر : دار الكتاب العربي للطباعة والنشر ، ســنة

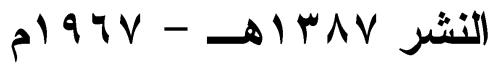

تصحيح الفصيح وشرحه لابن دُرُسنتوَيَهْ ابن المرزبـــان ، تحقيــق : د. محمــد بــدوي المختهـون ، المجلـس الأعلــى للثــئون الإســلامية

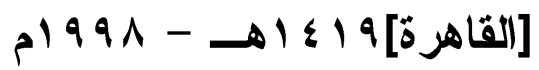

• التصريح على التوضيح أو التصريح بمضمون التوضيح في النحو لخالد

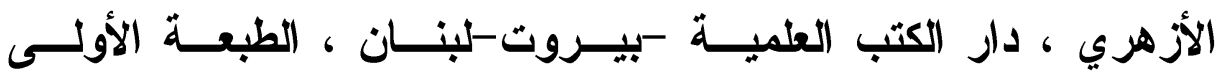

$$
\text { - مr...- } 1 \leq r 1
$$

تعليق الفرائد على تسهيل الفوائد للاماميني ، تحقيق : د/ محمد بن عبد الرحمن بن محمد المفدى ، الناشر : بدون الطبعة الأولى ب . ع 1 هـ - $19 \wedge \mu$

• تفسير الطبري = جامع البيان في تأويل القرآن لأبي جعفر الطبــري ، تحقيث : أحمد محمد شــاكر ، مؤسســة الرســالة ، الطبعــة الأولـى لـ - $r \ldots-.$.

تفسير القرطبي = الجامع لأحكام القرآن للقرطبـي ، تحقيـق : أحمـــ البردوني وإبر اهيم أطفيش ، دار الكتب المصــرية - القـــاهرة الطبعــة

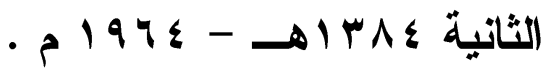

• تفسير القرآن العزيز لابن أبي زمَنِين المالكي تحقيق : أبــو عبـــ الله

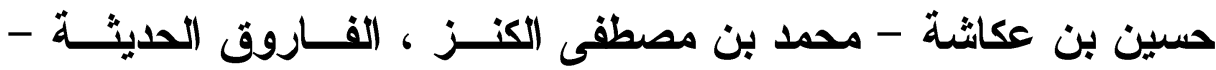

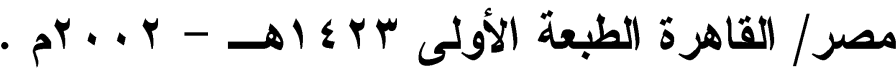


تقويم اللسان لجمال الاين الجوزي ، تحقيق : د. عبد العزيــز مطــر ،

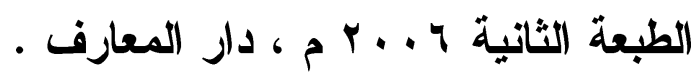
التكملة والأيل والصلة لكتاب تاج اللغة وصحاح العربيــة للحسـن بـن محمد بن الحسن الصغاني ، حقق الجزء الخامس إبــراهيم إســـماعيل الأبياري ، راجعه محمد خلف الله أحمد ، مطبعة دار الكتب القاهرة سنة - p) $9 \mathrm{VV}$

تمهيد القواعد بشرح تسهيل الفوائد لناظر الجيش ، دراسة وتحقيق : أ. د. علي محمد فاخر وآخرون ، دار السلام القاهرة - جمهورية مصــر

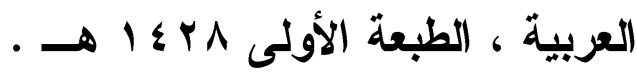
• تهذيب اللغة للأزهري اللهروي، ، تحقيق : محمد عوض مرعب الناشر : دار إحياء التراث العربي - بيروت الطبعة الأولى I + . بم • توضيح المقاصد والمسالك بشرح ألفية ابن مالــك للمــر ادي ، شــرح وتحقيق : عبد الرحمن علي سليمان ، دار الفكر العربي الطبعة الأولـى - $r$ r. تيسير البيان لأحكام القرآن لمحمد بن علي اليمني الثـــافي ، بعنايــة جامع الأصول في أحاديث الرسول لمجد الدين أبو السعادات ابن الأثير ، تحقيق : عبد القادر الأرنؤوط - التتمة تحقيق بشير عيـون ، مكتبــة الحلواني - مطبعة الملاح - مكتبة دار البيان الطبعة الأولى • • جامع الأصول في أحاديث الرسول لمجد الدين أبو السعادات (بن الأثير ، تحقيق : عبد القادر الأرنؤوط - التتمة تحقيق بشير عيـون ، مكتبــة الحلواني - مطبعة الملاح - مكتبة دار البيان الطبعة الأولى •

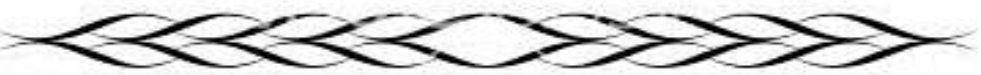


الترقير الدولخ ISSN 2356-9050

• جامع الدروس العربية لمصطقى بن محمد سليم الغلايينــى ، المكتبــة

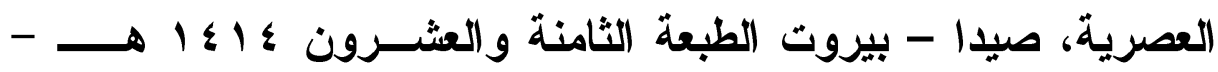
. 1994

• جامع المسانيد والسنُنَ الهادي لأقوم سنَنْ لأبي الفداء إسماعيل القرشي

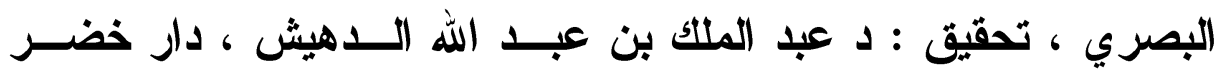

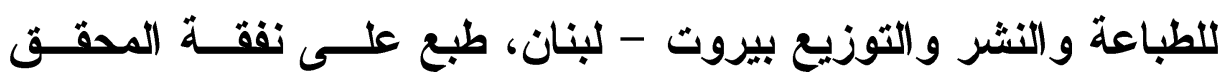

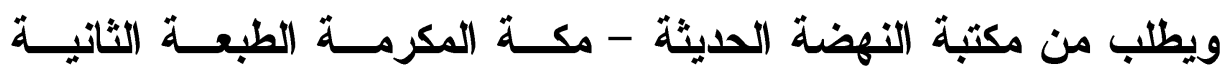
- $1991-0 \rightarrow 19$ • الجنى الداني في حروف المعاني للمرادي ، تحقيق : د فخر الدين قباوة

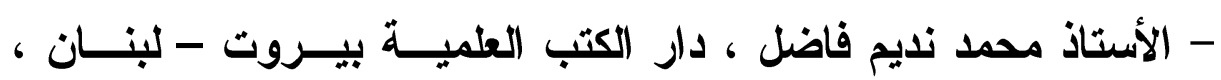

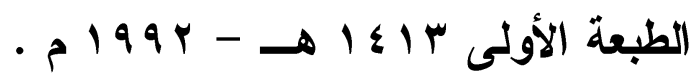

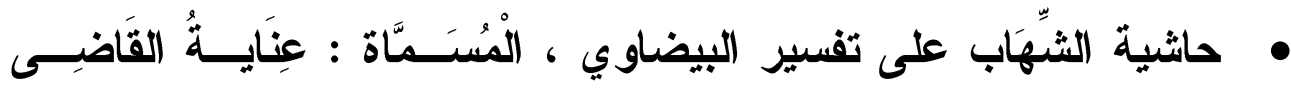

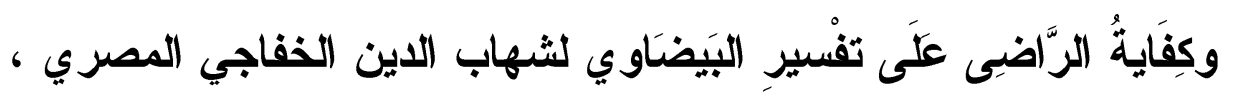

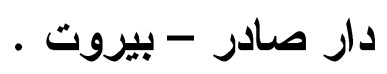

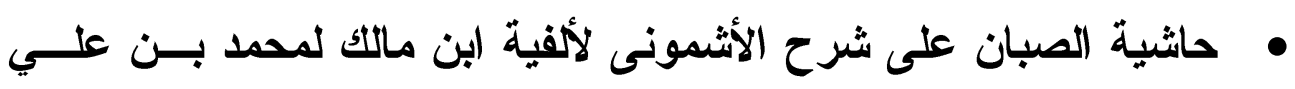

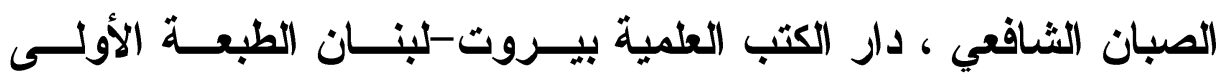
- م أ $99 \vee-1 \leqslant$

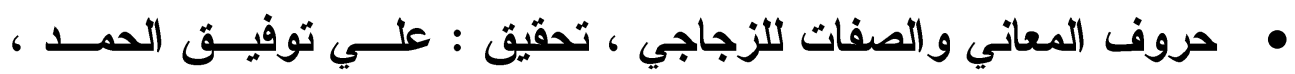

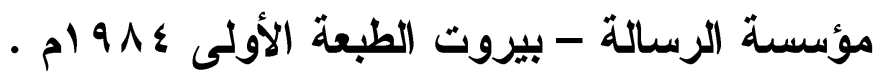

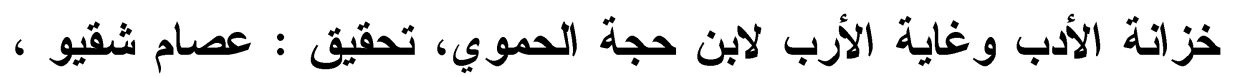

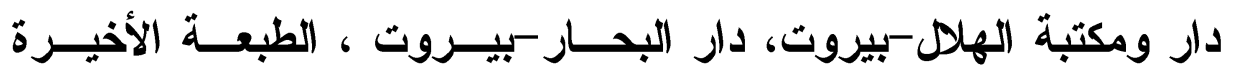
• م

\section{0}


خزانة الأبب ولب لباب لسان العرب لعبد القادر بن عمسر البغــدادي ، تحقيق وشرح عبد السدلام محمد هارون الناشــر : مكتبـة الخــانجي،

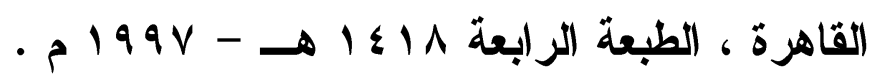

• الخصائص لأبي القتح عثمان بن جني ، الهيئة المصرية العامة للكتــاب

$$
\text { الطبعة : الر ابعة . الرئ }
$$

الدر المصون في علوم الكتاب المكنون للسمين الحلبي ، تحقيق الاكتور

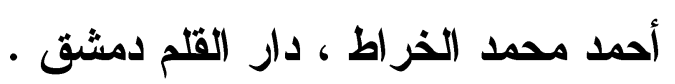
درة الغواص في أوهام الخواص للحريري البصري ، تحقيـق عرفــات

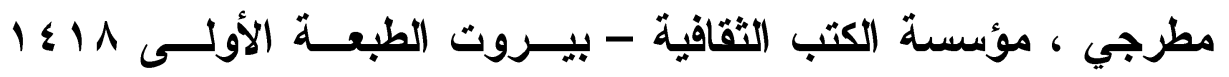

$$
\text { - } 1991 / 0
$$

ديوان أبي الأسود الاؤلي ، صنعه أبي سعيد الحسن السكري ، تحقيـق الثيخ محمد حسن آل ياسين ، دار ومكتبــة الهـــلمل الطبعــة الثانيــة

$$
\text { - } 1991 / \Delta 1 \leq 11
$$

ديوان البحتري ، مطبعة هندية بالموسكي بمصــر ، الطبعـة الأولـى

$$
\text { م } 1911 / 01 \% q
$$

• الزاهز في معاني كلمات الناس لأبي بكر الأبباري ، تحقيق : د. حــاتم صالح الضامن ، الناشر : مؤسسة الرسالة - بيزوت ، الطبعة الأولـى - $199 r-\rightarrow 1 \leqslant 1 r$

رسالة الملائكة - نشرها الميمني ملحق بكتاب (أبو العلاء ومـــا إليــهـ) لأبي العلاء المعري ، تحقيق عبد العزيز الميمني ، دار الكتب العلمية -

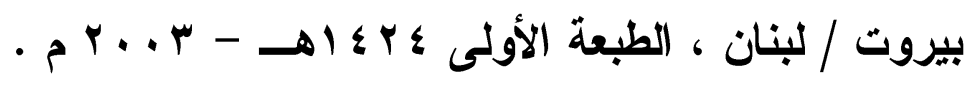


الترقير الدوله ISSN 2356-9050

• سر صناعة الإعراب لأبي الفتح عثمان بن جني ، دار الكتـب العلميــة

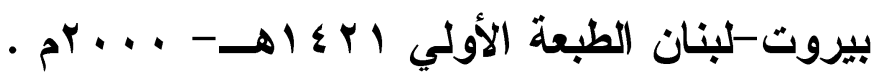

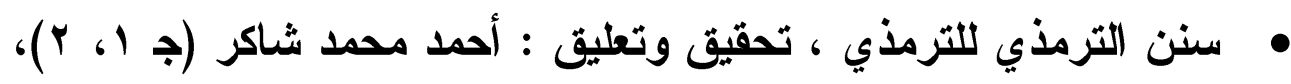

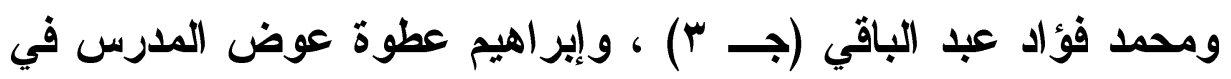
الأزهر الثريف (ج ع، 0) ، شركة مكتبة ومطبعسة مصــطفى البـابي

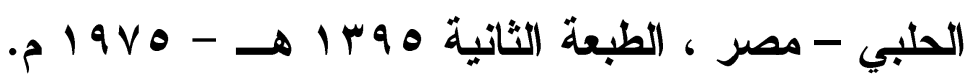

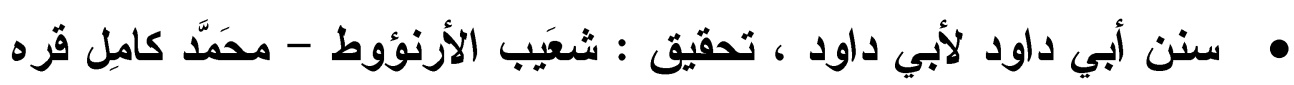

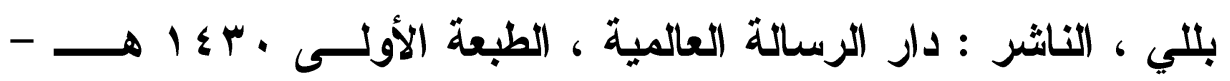
- r. 9

السنن الكبرى لأحمد بن الحسين أبو بكر البيهقي تحقيق : محمد عبـــ

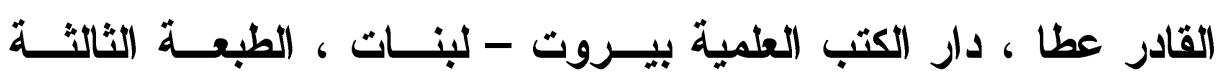

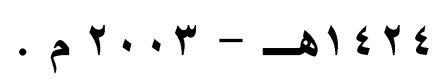

• السنن الكبرى لأحمد بن شعيب بن علي الخراساني النسائي ، تحقيق :

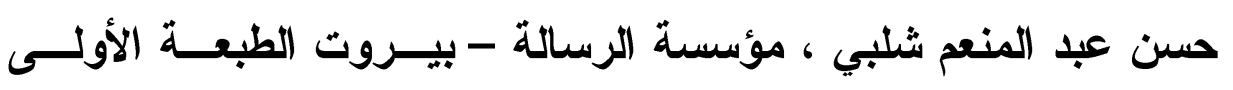

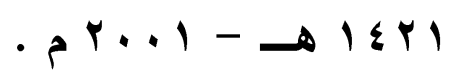

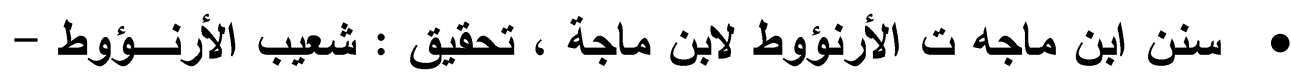

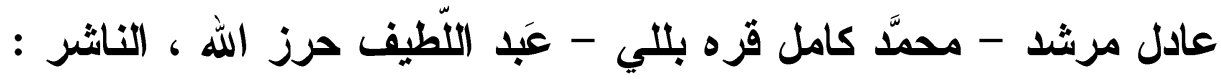

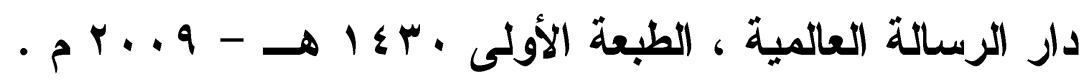

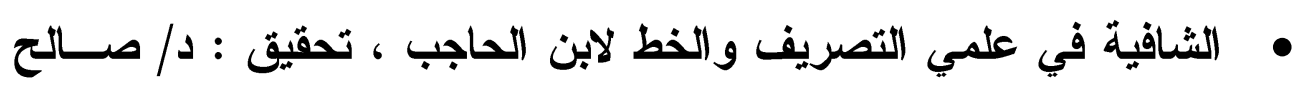

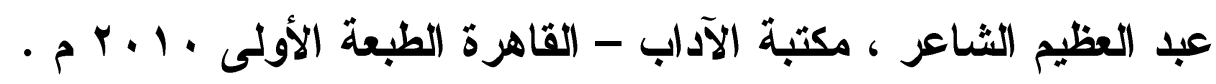

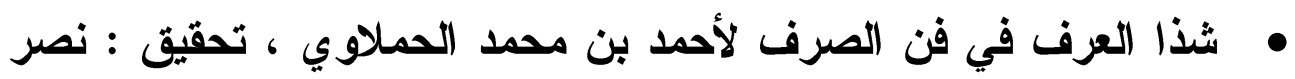

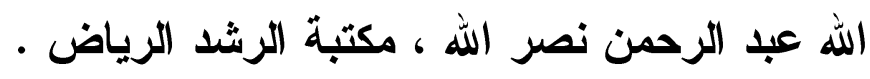

\section{0}




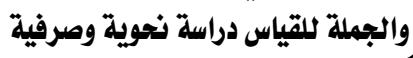

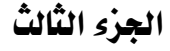

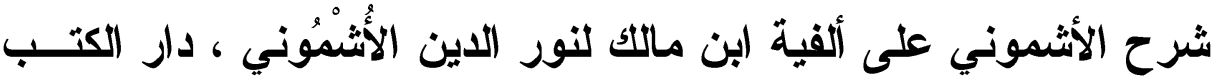

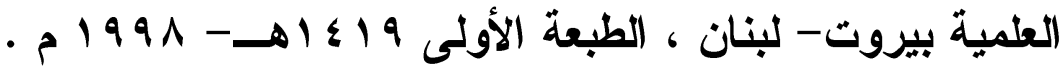
شرح تسهيل الفوائد لابن مالكك الطائي الجيـاني ، تحقيـق : د. عبــــ الرحمن السيد ، د. محمد بدوي المختون ، الناثــر : هجـر للطباعــة و النشر و التوزيع والإعلان الطبعة الأولى ( . أ اهـ - . 99 ام) .

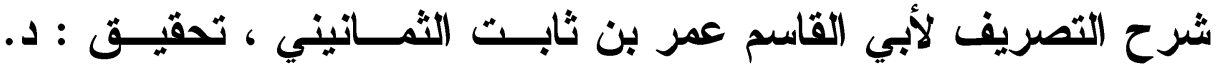

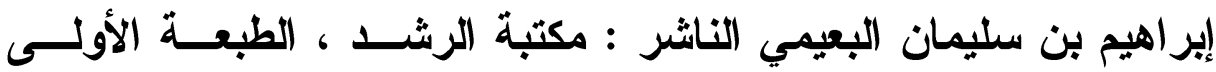
. $1999-81 \leq 19$ شرح درة الغواص في أوهام الخواص (مطبوع ضــمن الدرة الغــواص

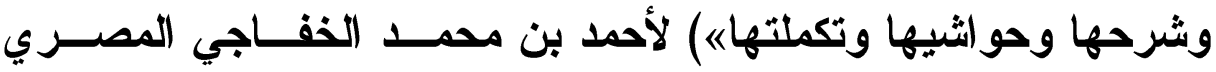
تحقيق : عبد الحفيظ فرغلي علي قرني ، دار الجيل، بيروت - لبنــان ،

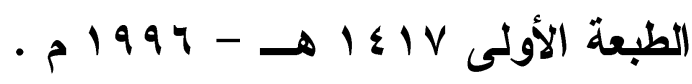
هرح شافية (بن الحاجب مع شرح شواهده لعبد القادر البذادي صاحب

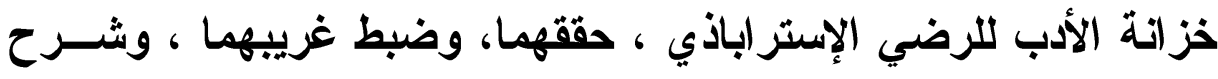

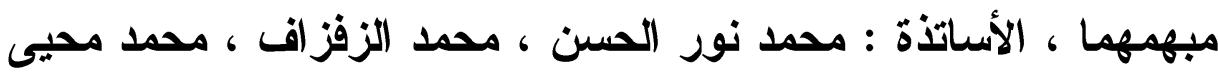

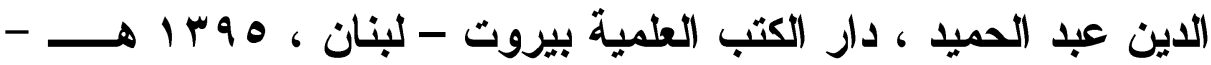
- 19v0 • شرح الطيبي على مشكاة المصابيح المسمى بـ (الكاثشف عن حقـائق

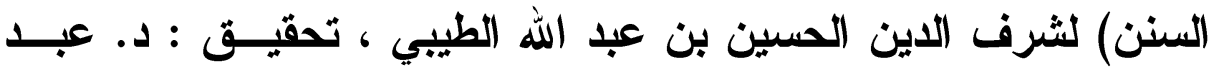

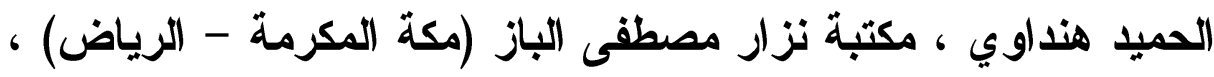

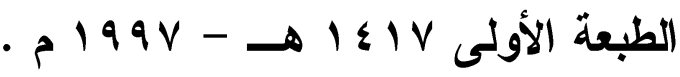

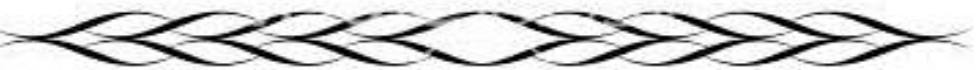




\section{الترقير الدولخ}

ISSN 2356-9050
Q
حولية كلية اللفة العربية بجرجا مجلة علمية محكمة

• شرح ابن عقيل على ألفية (بن مالكك لابن عقيل ، تحقيق : محمد محيي الدين عبد الحميد ، دار التراث - القاهرة دار مصر للطباعـة ، ســعيد

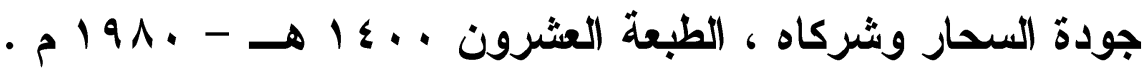

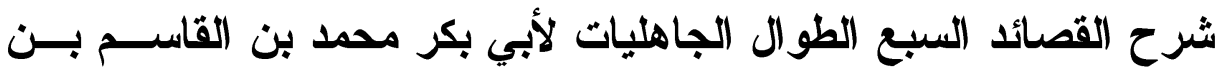

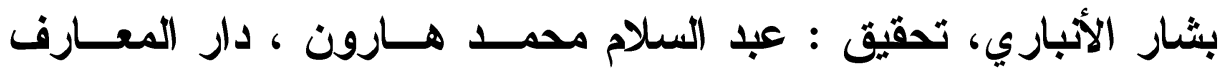

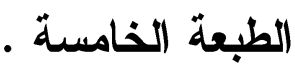

• شرح الكافية الثافية لابن مالك الطائي الجياني ، تحقيق : عبد المــنم

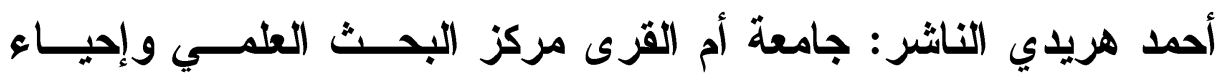

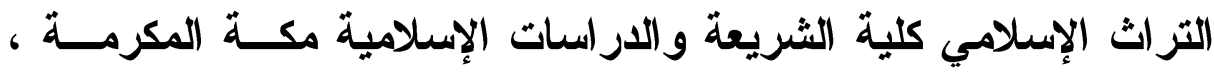

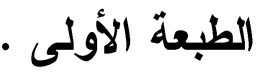

• شرح كتاب سيبويه لأبي سعيد السيرافي ، تحقيق : أحمد حسن مهدلي

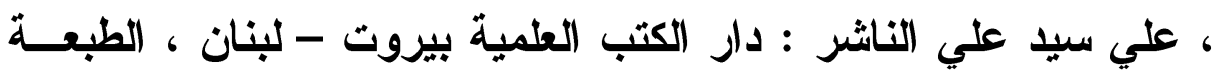

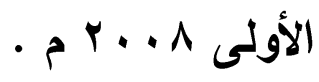

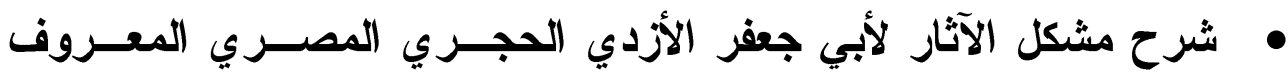

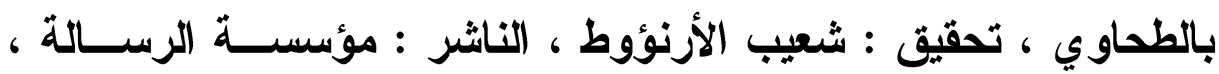

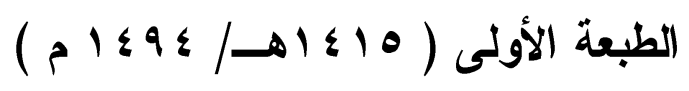

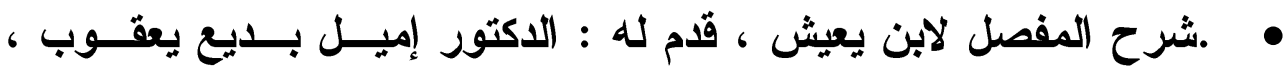

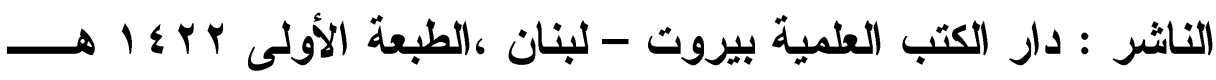
$\cdot$ r... I-

• شرح المقدمة المحسبة لطاهر بن أحمد بن بابثاذ ، تحقيق : خالد عبد

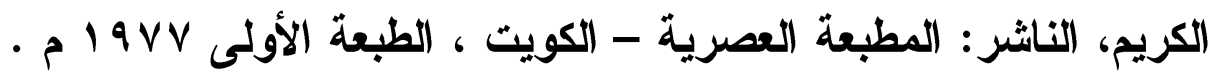


شرح المكودي على الألفية لأبي زيد عبد الرحمن بن علي بـن صــالح

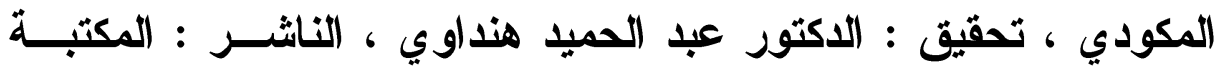

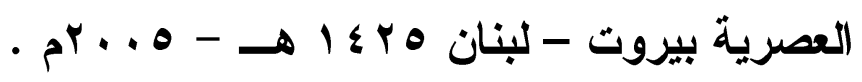

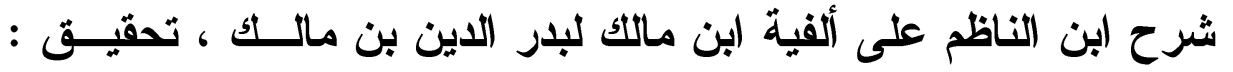

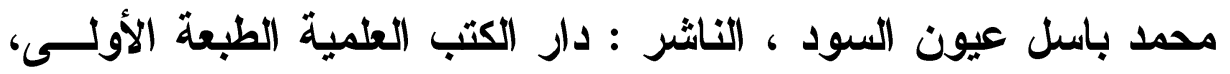

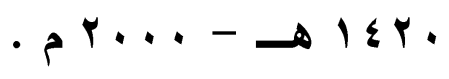

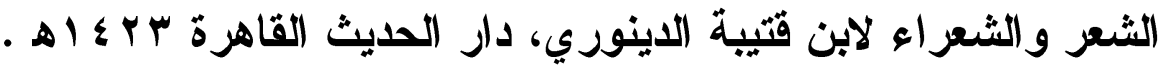
الثفا بتعريف حقوق المصطفى - مذيلا بالحاثية المسماة مزيل الخفاء

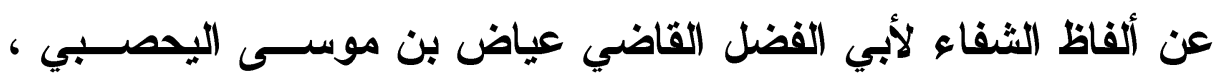

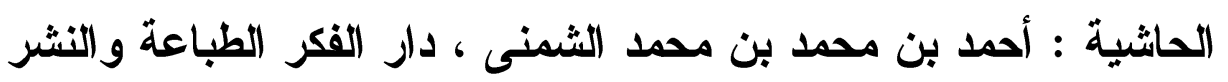

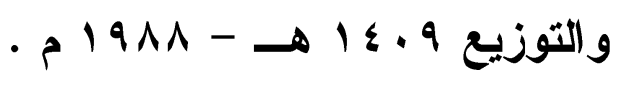

• شواهد التوضيح والتصحيح لمشكلات الجامع الصَّحيح لابن مالك الطائي

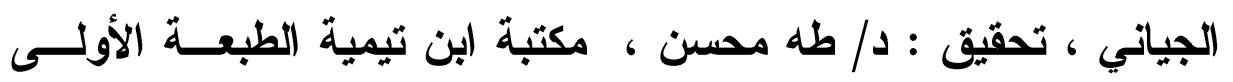
. $1 \leqslant .0$

• الصاحبي في فقه اللغة العربية ومسائلها وسنن العرب في كلامها لأحمد

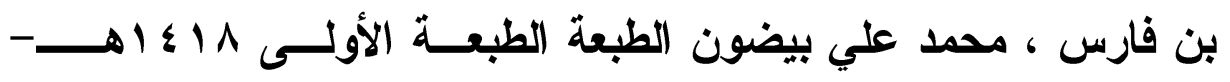
. مان

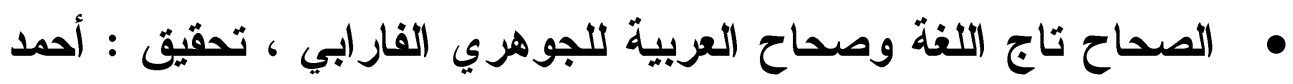

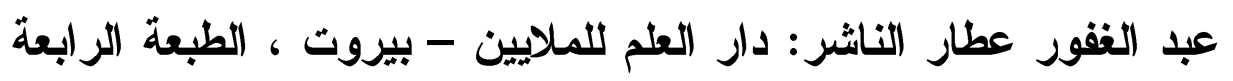

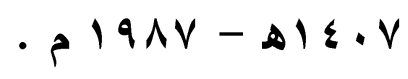

صحيح البخاري = الجامع المسند الصحيح المختصر من أمور رســول الله صلى الله عليه وسلم وسنته وأيامه لمحمد بن إسماعيل أبو عبدالله

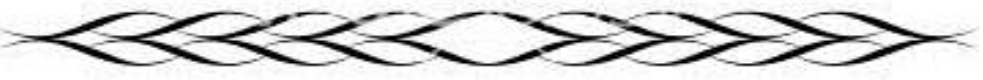




\section{الترقيم الدولخ}

ISSN 2356-9050

البخاري الجعفي ، تحقيق : محمد زهير بن ناصر الناصر ، دار طــوق

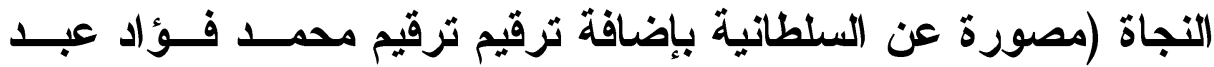

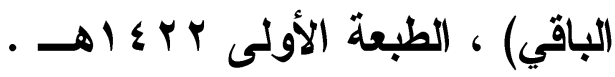

• صحيح مسلم = المسند الصحيح المختصر بنقل العدل عن العــل إلــى رسول الله صلى الله عليه وسلم لمسلم بن الحجاج أبو الحسن القثيري النيسابوري ، تحقيق : محمد فؤاد عبد البــاقي ، دار إحيــاء التـــراث العزبي - بيروت

• ضياء السالك إلى أوضح المسالك لمحمد عبد العزيز النجار ، الناشــر :

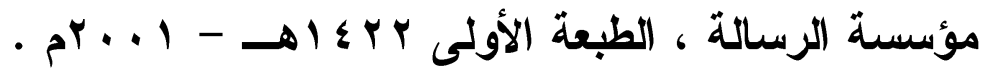
الطرق الحكمية لابن قيم الجوزية ، مكتبة دار البيان . • العقد القريد لأحمد بن محمد بن عبد ربه ، دار الكتب العلمية - بيروت الطبعة الأولى ع . ع 1 هـ . • عقود الزبرجد على مسند الإمام أحمد في إعراب الحديث لجلال الــدين السيوطي ، تحقيق : حسن موسى الثـاعر ، مجلة الجامعة الإســلامية بالمدينة المنورة .

• عمدة الحفاظ في تفسير أثرف الألفاظ للسمين الحلبي تحقيق : محمـــ

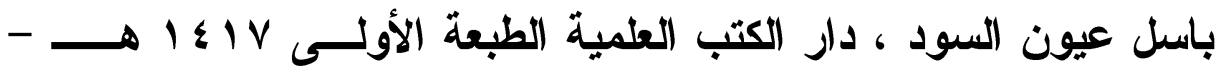
- 1997

عمدة القاري شرح صحيح البخاري لبلر الــدين العينـى ، دار إحيــاء

$$
\text { التراث العربي - بيروث }
$$

\section{0}




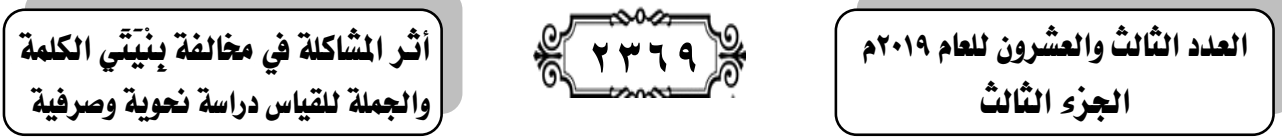

• علل النحو لأبي الحسن ابن الوراق ، تحقيق : محمــود جاســـم محمـــ الارويش ، مكتبة الرشد - الريــاض / الســعودية الطبعــة الأولــى، - p) $999-\rightarrow 1 \leqslant r$.

• العين للخليل بن أحمد ، تحقيق : د مهــــي المخزومــي ، د إبـر اهيم السامر ائي ، دار ومكتبة الهلال .

• غريب الحديث لأبي عُبيد القاسم بن سلام بن عبد الله الهروي ، تحقيق: د. محمد عبد المعيد خان ، مطبعة دائرة المعارف العثماتية، حيدر آباد-

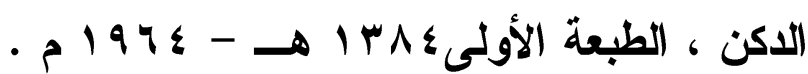
• الفاخر للمفضل بن سلمة بن عاصم ، تحقيق : عبد العليم الطحـاوي ، مراجعة محمد علي النجار ، دار إحياء الكتب العربيــة عيســى البــابي

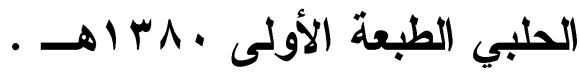
فتح الباري شرح صحيح البخاري لزين الدين عبد الــرحمن السَــلامي، البغدادي ، تحقيق: محمود بن شعبان بن عبد المقصــود.، وآخـرين ، مكتبة الغزباء الأثرية - المدينة النبوية ، الحقوق : مكتب تحقيـق دار

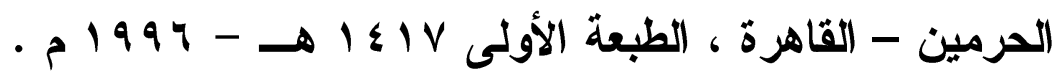
فقه اللغة وسر العزبية لأبي منصور الثتعالبي ، تحقيق : عبـــ الــرزاق

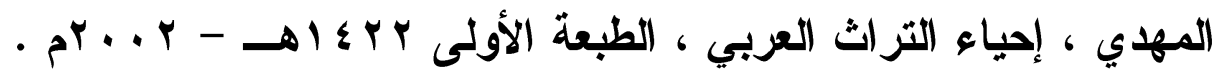
القاموس المحيط للقيروزآبادى ، تحقيق : مكتب تحقيـق التــــراث فـي مؤسسة الرسالة بإثر اف: محمد نعيم العرقسؤسي ، الناشر : مؤسســة الرسالة للطباعة والنشر والتوزيع بيـروت - لبنــان الطبعـة الثامنــة

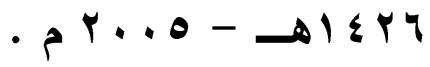

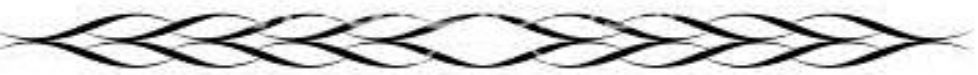




\section{الترقير الدولخ \\ ISSN 2356-9050}

• الكتاب لسيبويه ، تحقيق : عبد السلام محمد هارون ، مكتبة الخــاتجي

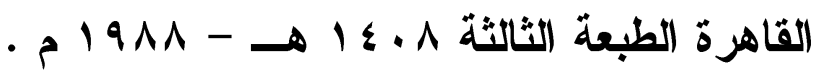
• كتاب الأفعال لابن الحداد ، تحقيق : حسـين محمـــ محمـــ شــرف ، مر اجعة: محمد مهدي ، مؤسسة دار الشعب للصحافة والطباعة والنشر،

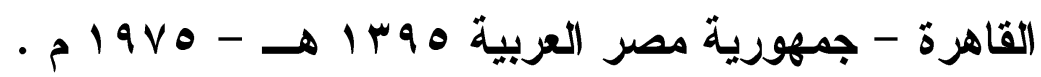
كتاب الأفاظ لابن السكيث ، تحقيق : د. فخر الاين قباوة ، مكتبة لبنان ناشرون الطبعة الأولى 99 ام . الكليات معجم في المصطلحات والفروق اللغويــة لأيــوب بـن موســى الحسيني القريمي الكفوي ، أبو البقاء الحنفي ، تحقيق : عدنان درويش - محمد المصري ، الناشر : مؤسسة الرسالة - بيروت . • الكناش في فني النحو والصرف لأبي الفــــاء ، دراســـة وتحقيــق : د/ رياض بن حسن الخوام ، المكتبة العصرية للطباعة والنشر، بيــروت -

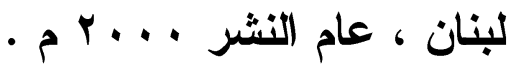
لسان العرب لابن منظور ، الناشر : دار صادر بيروث ، الطبعة الثالثـة $\rightarrow 1 \leq 1 \leq$

اللباب في علل البناء والإعراب لأبي البقاء العكبري ، تحقيق : د. عبد

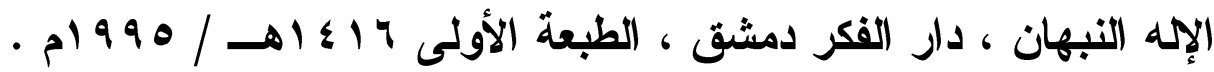
اللمحة في شرح الملحة لأبي عبد الله شمس الاين ، المعـروف بـابن الصائغ ، تحقيق : إبراهيم بن سالم الصاعدي ، الناشر : عمادة البحث العلمي بالجامعة الإسلامية المدينة المنورة ، المملكة العربية السعودية ،

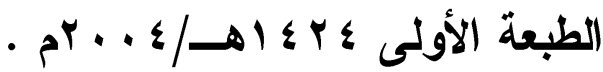

\section{0}


ليس في كلام العرب لابن خالويه ، تحقيق : أحمد عبد الغقور عطـار ،

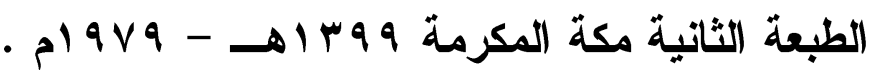

المحتسب في تبيين وجوه شواذ القراعات والإيضاح عنها لأبـي الفــتح عثمان بن جني ، وزارة الأوقاف-المجلس الأعلى للثــئون الإســلامية

$$
\text { - p) } 999-\rightarrow \leq r \text {. }
$$

• المحكم والمحيط الأعظم لأبي الحسن علي بــن إســماعيل بـن ســيده المرسي ، تحقيق : عبد الحميا هنداوي ، الناشر : دار الكتب العلمية -

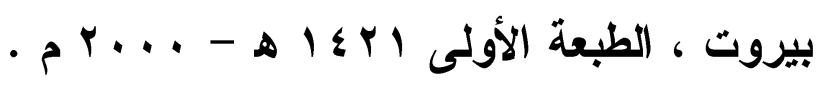

مختصر في شواذ القرآن من كتاب البديع لابن خالويه ، عنى بنشره ج • برجشتر اسر ، مكتبة المتتبي القاهرة .

مرقاة المفاتيح شرح مشكاة المصابيح لنور الاين الملا الهروي القاري، دار الفكر ، بيزوت - لبنان الطبعة الأولى r r \& أه - r . . rم . المزهر في علوم اللغة وأنواعها لجلال الدين السيوطي ، تحقيق فـؤاد

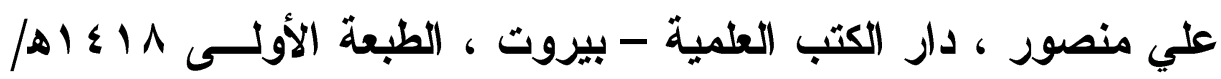
- 199

• المسائل العسكريات في النحو العربي لأبي علي النحوي ، تحقيـق : د. علي جابر المنصوري ، الناشر: (الدار العلمية الدولية للنشر والتوزيــع

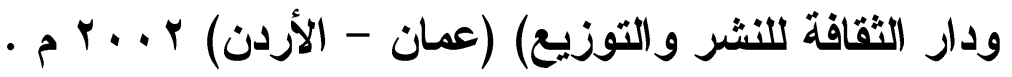
المساعد على تسهيل الفوائد لبهاء الاين بن عقيل ، تحقيق : د. محمد كامل بركات - الناشر: جامعة أم القرى (دار الفكر دمشث - دار المدني

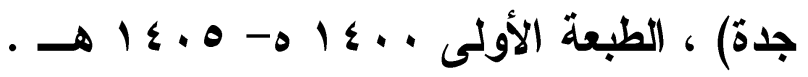

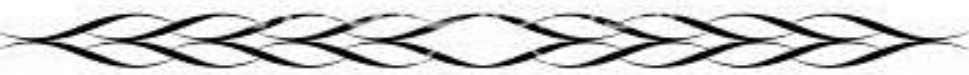




\section{الترقيم الدوله ISSN 2356-9050}

• مسند الإمام أحمد بن حنبل لأحمد بن محمد بن حنبل ، تحقيق : أحمـــ

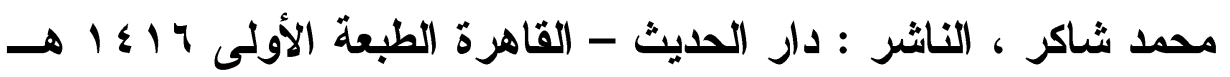
- $1990-$

مسند البزار المنشور باسم البحر الزخار لأبي بكر أحمـــــــن عـــرو المعروف بالبزار ، تحقيق محفوظ الرحمن زين الله (حقق الأجزاء مسن ا إلى 9) ، وعادل بن سعد (حقى الأجزاء من · 1 (إلى IV) ، وصبري عبد الخالق الثافعي (حقق الجزء 1 1) ، مكتبة العلوم والحكم - المدينة

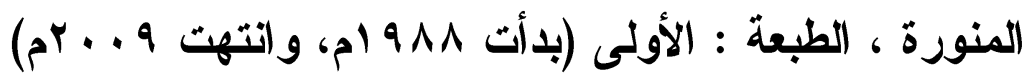
• مسند الشهاب لأبي عبد الله محمد بن سلامة بن جعفر بـن علــي بـن حكمن القضاعي المصري ، تحقيق : حمدي بن عبد المجيا الســلفي ،

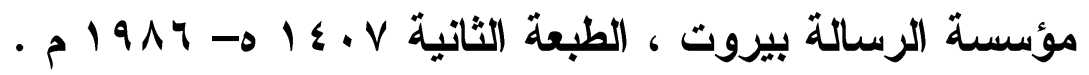
مصابيح الجامع لبدر الاين المعروف بالاماميني ، اعتنى بــه تحقيةـــا وضبطا وتخريجا: نور الدين طالب ، دار النوادر سوريا ، الطبعة الأولى

$$
\text { . } r . q-\rightarrow 1 \leq r \text {. }
$$

• المصباح المنير في غريب الثرح الكبير المؤلف : أحمد بن محمد بـن علي القيومي ، الناشر : المكتبة العلمية - بيزوت . • معالم السنن وهو شرح سنن أبي داود لأبي سليمان حمد بن محمد بـن إبراهيم بن الخطاب البستي المعروف بالخطابي ، المطبعة العلمية حلب ،

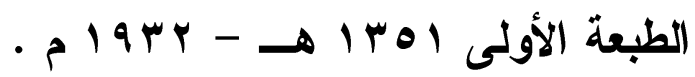
معاهد التنصيص على شواهد التخخيص لعبد الرحيم بن عبد الرحمن بن أحمد، أبو القتح العباسي ، تحقيق : محمد محيي الاين عبــــ الحميـــ ، عالم الكتب - بيروث . مات

\section{0}




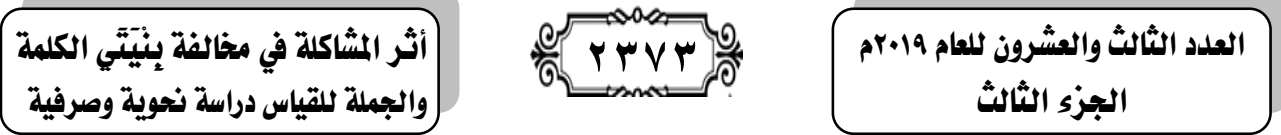

• معجم ديوان الأدب لأبي إبراهيم إسحاق بـن إبــراهيم بـن الحسـين الفارابي، تحقيق : دكتور أحمد مختار عمر ، مراجعة : دكتور إبـر اهيم أنيس ، طبعة : مؤسسة دار الثعب للصحافة والطباعة والنشر القاهرة،

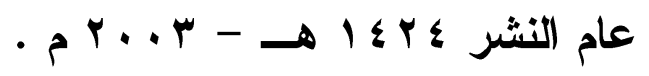

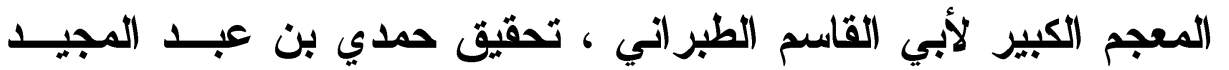
السلفي ، مكتبة ابن تيمية القاهرة ، الطبعة الثانية . المغرب في ترتيب المعرب لبرهان الاين الخــوارزمي المُطَــرّزّ ، دار

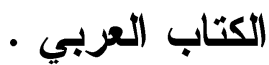

مغني اللبيب عن كتب الأعاريب لابن هثام ، تحقيق : د. مازن المبارك/

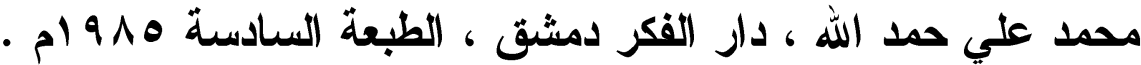
مفتاح العلوم للخوارزمي ، ضبطه وكتب هوامشه وعلق عليـهـ : نعـيم زرزور ، دار الكتب العلمية بيروت ـ لبنان ، الطبعة الثانية V • ع اهـ - $19 \wedge \mathrm{V}-$

• المفتاح في الصرف لأبي بكر عبد القاهر الجرجاني ، حققه وقدم لله :دة اله علي توفيق الحمد ، مؤسسة الرســالة - بيـروت ، الطبعــة الأولــى - $19 \wedge v-\rightarrow 1 \varepsilon \cdot v$

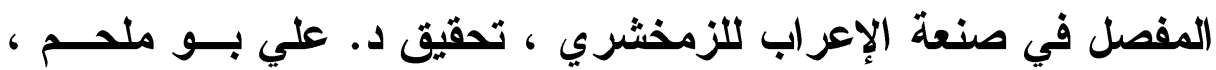

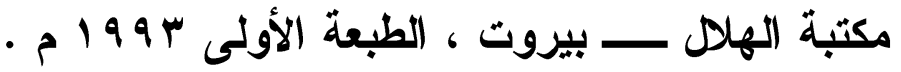
مقاييس اللغة لأحمد بن فارس ، تحقيق : عبد السلام محمد هــارون ،

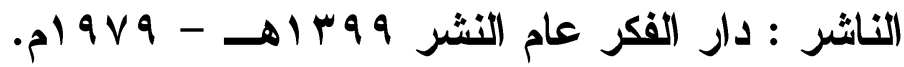

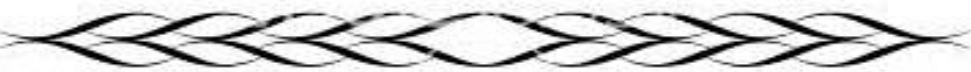




\section{الترقيم الدوله \\ ISSN 2356-9050}

• المقصد العلي في زوائد أبي يعلى الموصلي لأبي الحسن نور الدين علي

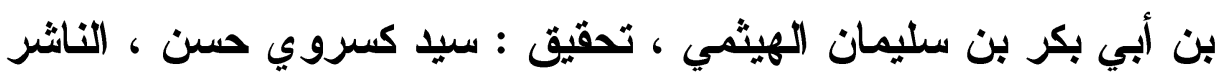

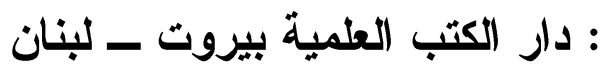

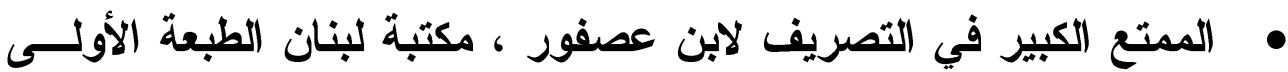
. pl997

• منحة الباري بشرح صحيح البخاري المسمى " تحفة البـاري " لـزين

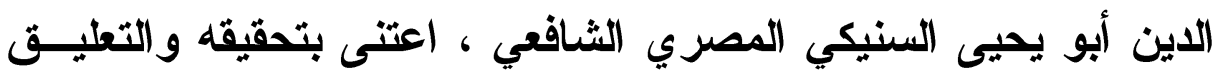

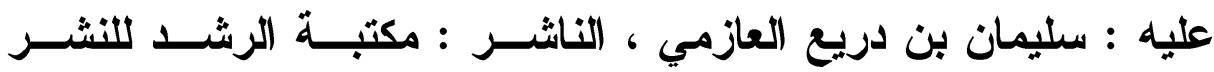

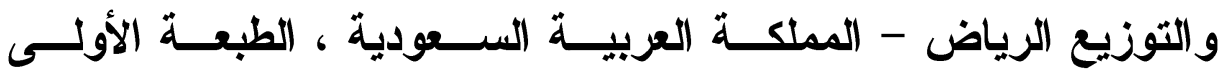

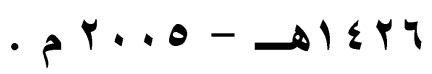

• المنصف لابن جني، شرح كتاب التصريف لأبي عثمان المسازني ، دار

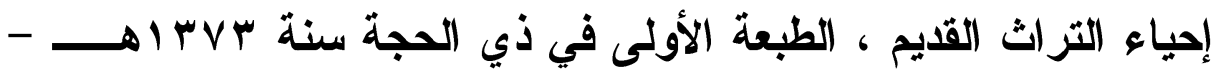

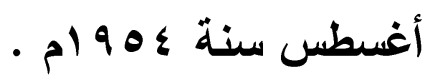

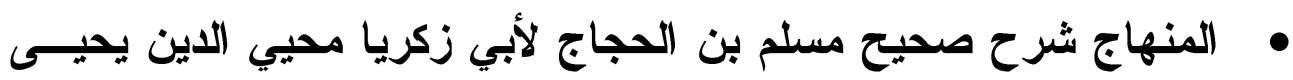

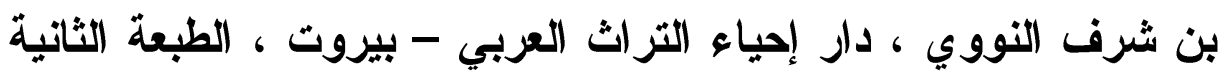
. olrar

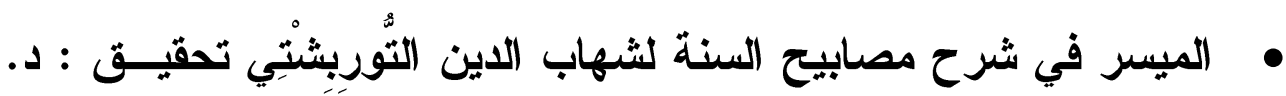

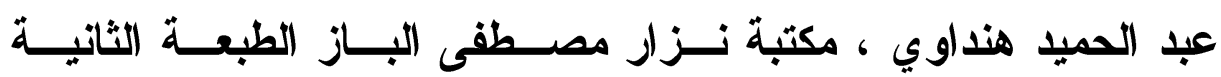

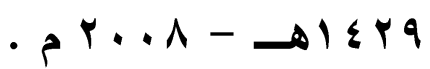
النشر في القراعات العشر لثمس الدين ابن الجزري ، المحقق : علــي محمد الضباع ، المطبعة التجارية الكبرى (تصوير دار الكتاب العلمية). 
النهاية في غريب الحديث والأثر لأبي السعادات الشيباني الجزري ابــن

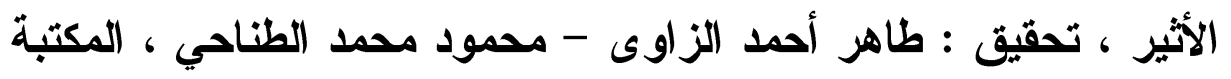

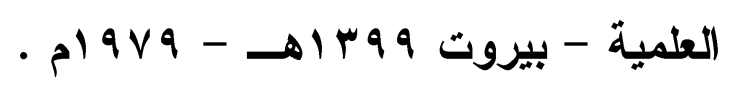

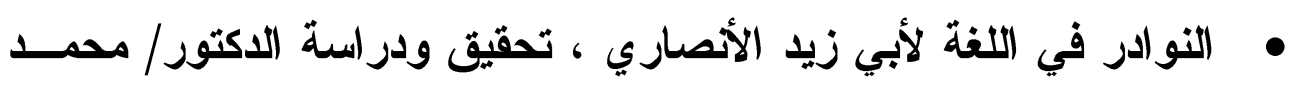

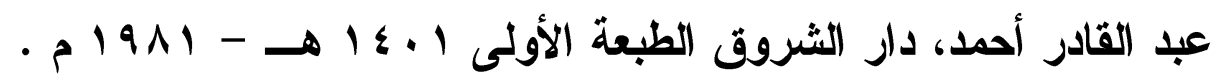

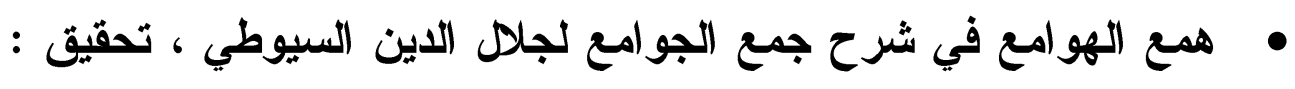

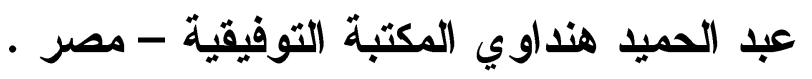




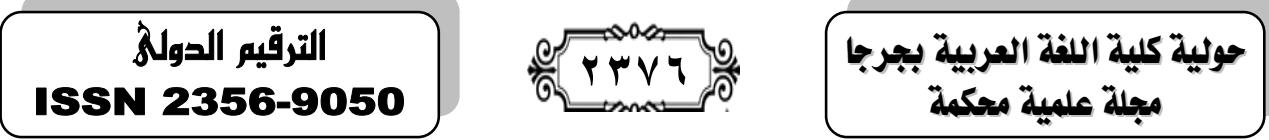

فهـرس الإوضوكات

\begin{tabular}{|c|c|c|}
\hline |لصفمة & الإوضوع & $p$ \\
\hline rrqv & هلخص البحث & .1 \\
\hline rpqA & Research Summary &. r \\
\hline r $r q q$ & الاقدهمة &.$r$ \\
\hline$r \mu \cdot \varepsilon$ & الدراسات السابقة &.$\varepsilon$ \\
\hline$r \mu \cdot q$ & التشههيد : المشاكلة والمزاوجة والإتباع والماذاة & .0 \\
\hline rri & اه مشاكلة اللفظ للفظ & .7 \\
\hline rmi & rـ مشاكلة اللافظ للمهنى &.$v$ \\
\hline Trot & الخاتمهة &.$\wedge$ \\
\hline rrov & بأهم المسادر والمراجع & .9 \\
\hline rmVY & فهرس الإوضوعات & 1. \\
\hline
\end{tabular}

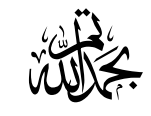

